PNL-9335

UC-602

\title{
Review of Potential Subsurface Permeable Barrier Emplacement and Monitoring Technologies
}
W. H. Riggsbee
R. M. Schwarz
R. L. Treat
K. J. Cantrell
H. J. Stansfield
S. J. Phillips

February 1994

Prepared for the U.S. Department of Energy under Contract DE-AC06-76RLO 1830

Pacific Northwest Laboratory

Operated for the U.S. Department of Energy by Battelle Memorial Institute 


\title{
DISCLAIMER
}

This report was prepared as an account of work sponsored by an agency of the United States Government. Neither the United States Government nor any agency thereof, nor Battelle Memorial Institute, nor any of their employees, makes any warranty, expressed or implied, or assumes any legal liability or responsibility for the accuracy, completeness, or usefulness of any information, apparatus, product, or process disclosed, or represents that its use would not infringe privately owned rights. Reference herein to any specific commercial product, process, or service by trade name, trademark, manufacturer, or otherwise does not necessarily constitute or imply its endorsement, recommendation, or favoring by the United States Government or any agency thereof, or Battelle Memorial Institute. The views and opinions of authors expressed herein do not necessarily state or reflect those of the United States Government or any agency thereof.

\author{
PACIFIC NORTHWEST LABORATORY \\ operated by \\ BATTELLE MEMORIAL INSTITUTE \\ for the \\ UNITED STATES DEPARTMENT OF ENERGY \\ under Contract DE-ACO6-76RLO 1830
}

Printed in the United States of America

Available to DOE and DOE contractors from the

Office of Scientific and Technical Information, P.O. Box 62, Oak Ridge, TN 37831; prices available from (615) 576-8401. FTS 626-8401.

Available to the public from the National Technical Information Service, U.S. Department of Commerce, 5285 Port Royal Rd., Springfield, VA 22161. 
PNL-9335

UC-602

\title{
Review of Potential Subsurface Permeable Barrier Emplacement and Monitoring Technologies
}

\author{
W. H. Riggsbee (a) \\ R. L. Treat ${ }^{(\mathbf{a})}$ \\ H. J. Stansfield (a) \\ R. M. Schwarz ${ }^{(a)}$ \\ K. J. Cantrell \\ S. J. Phillips ${ }^{(\mathbf{b})}$
}

February 1994

Prepared for the U.S. Department of Energy under Contract DE-AC06-76RLO 1830

Pacific Northwest Laboratory

Richland, Washington 99352
(a) Ebasco Environmental Richland, Washington
(b) Westinghouse Hanford Company
Richland, Washington




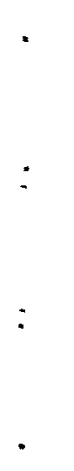




\section{Executive Summary}

Barriers are one of the most common and cost-effective methods for containment of disposed waste materials. The purpose of a barrier is to contain and/or limit the spread of contamination to within the confines of a waste disposal zone. Barrier technologies employ physical, thermal, chemical, and/or biological methods to eliminate or reduce contaminant mobility to acceptable levels.

This report focuses on subsurface permeable barrier technologies potentially applicable to existing waste disposal sites. This report describes candidate subsurface permeable barriers, methods for emplacing these barriers, and methods used to monitor the barrier performance. Two types of subsurface barrier systems are described: 1) those that apply to contamination in the unsaturated zone, and 2) those that apply to groundwater and to mobile contamination near the groundwater table. These barriers may be emplaced either horizontally or vertically depending on waste and site characteristics.

Materials for creating permeable subsurface barriers are emplaced using one of three basic methods: injection, in situ mechanical mixing, or excavation-insertion. Injection is the emplacement of dissolved reagents or colloidal suspensions into the soil at elevated pressures. In situ mechanical mixing is the physical blending of the soil and the barrier material underground. Excavation-insertion is the removal of a soil volume and adding barrier materials to the space created. These three basic methods can be used for the emplacement of both horizontal and vertical barriers.

Major vertical barrier emplacement technologies include trenching-backfilling; slurry trenching; and vertical drilling and injection, including boring (earth augering), cable tool drilling, rotary drilling, sonic drilling, jetting methods, injection-mixing in drilled holes, and deep soil mixing. Major horizontal barrier emplacement technologies include horizontal drilling, microtunneling, compaction boring, horizontal emplacement, longwall mining, hydraulic fracturing, and jetting methods.

Subsurface barriers may be monitored to ensure the quality of barriers as they are being emplaced and to verify that material and installation specifications are met. Continuous or periodic monitoring over barrier design lifetimes may also be required to verify that the barrier is functioning as expected. The type and degree of quality control is determined by the specific barrier technology, the contaminants present, and the geologic/hydrogeologic conditions present at the site. Three quality control and monitoring methods are applicable to the installation and performance verification of permeable barriers: 1) inference by monitoring the emplacement process, 2) sampling and analysis, and 3) nondestructive monitoring. 


\section{Table of Contents}

Executive Summary $\ldots \ldots \ldots \ldots \ldots \ldots \ldots \ldots \ldots \ldots \ldots \ldots \ldots$ iii

1.0 Introduction to Barrier Technology $\ldots \ldots \ldots \ldots \ldots \ldots \ldots \ldots \ldots \ldots \ldots \ldots$

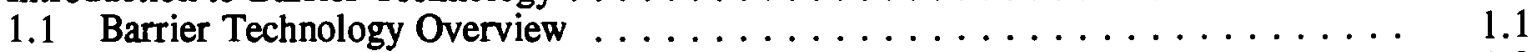

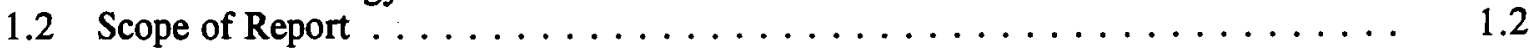

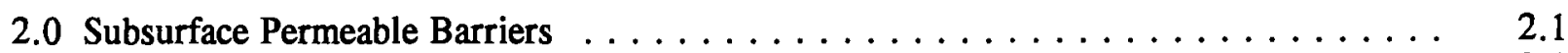

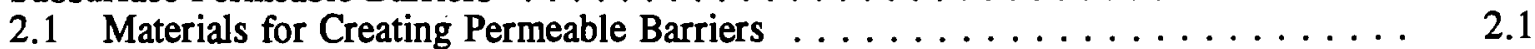

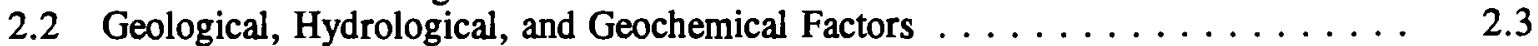

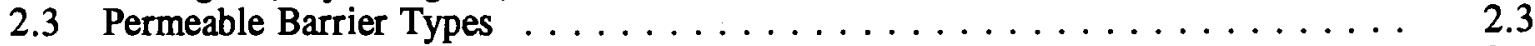

2.4 Composite Barriers . . . . . . . . . . . . . . . . . . . 2.4

3.0 Emplacement Methods $\ldots \ldots \ldots \ldots \ldots \ldots \ldots \ldots \ldots \ldots \ldots \ldots \ldots$

3.1 Vertical Permeable Barrier Emplacement Technologies . . . . . . . . . . . 3.1

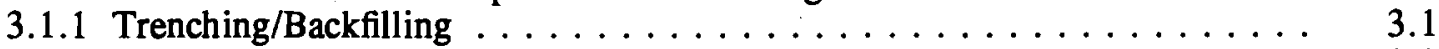

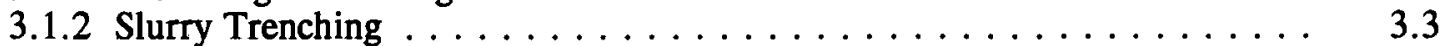

3.1.3 Vertical Drilling and Injection Techniques . . . . . . . . . . . 3.4

3.2 Horizontal Permeable Barrier Emplacement Technologies . . . . . . . . . . 3.15

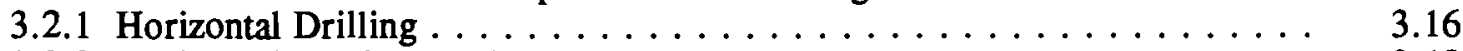

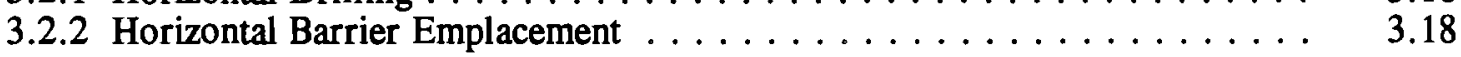

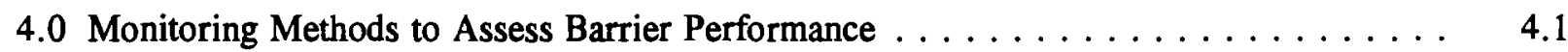

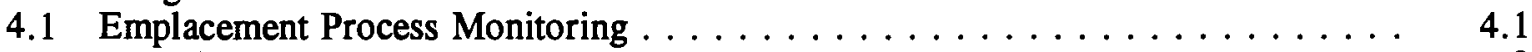

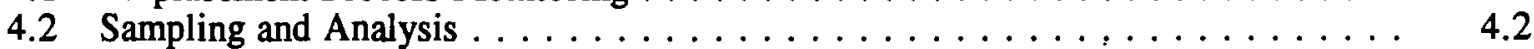

4.2.1 Borehole Sampling Techniques . . . . . . . . . . . . . 4.2

4.2.2 Groundwater Sampling Techniques $\ldots \ldots \ldots \ldots \ldots \ldots \ldots \ldots$

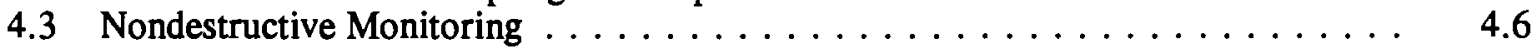

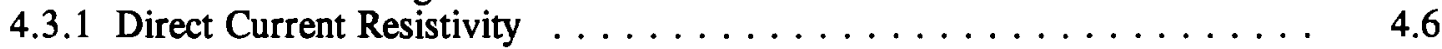

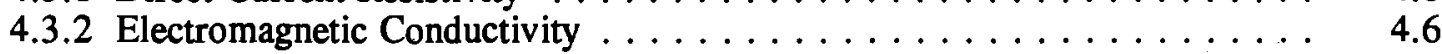

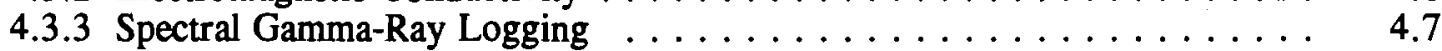

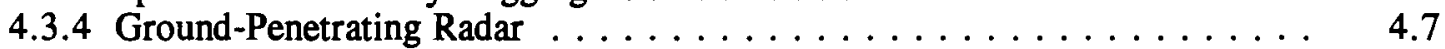

4.3.5 In Situ Subsurface Parameter Monitoring . . . . . . . . . . . . . 4.7

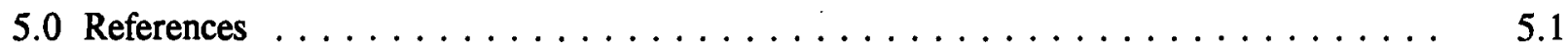

Appendix A - Layne Environmental $\ldots \ldots \ldots \ldots \ldots \ldots \ldots \ldots \ldots \ldots \ldots$ A.1

Appendix B - Onwego Drilling $\ldots \ldots \ldots \ldots \ldots \ldots \ldots \ldots \ldots \ldots \ldots \ldots \ldots$

Appendix C - Environmental West Exploration, Inc. $\ldots \ldots \ldots \ldots \ldots \ldots$. . . . . .

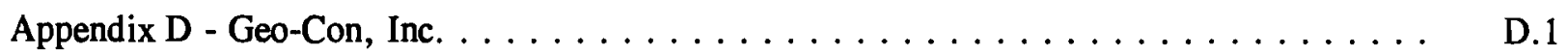




\section{Figures}

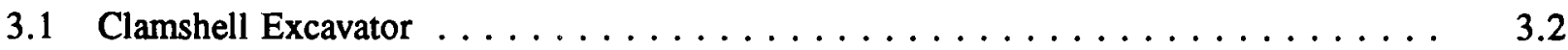

3.2 Dragline Excavator $\ldots \ldots \ldots \ldots \ldots \ldots \ldots \ldots \ldots \ldots \ldots \ldots \ldots \ldots$

3.3 Slurry Trenching $\ldots \ldots \ldots \ldots \ldots \ldots \ldots \ldots \ldots \ldots \ldots \ldots \ldots$

3.4 Rotary-Bucket Augering Machine $\ldots \ldots \ldots \ldots \ldots \ldots \ldots \ldots \ldots \ldots$

3.5 Hollow-Stem Augering Machine $\ldots \ldots \ldots \ldots \ldots \ldots \ldots \ldots \ldots$

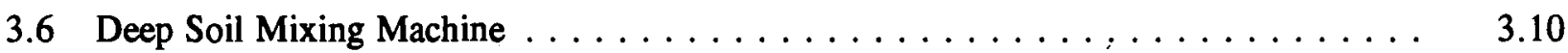

3.7 Cable Tool Drilling Machine $\ldots \ldots \ldots \ldots \ldots \ldots \ldots \ldots \ldots \ldots \ldots \ldots \ldots$

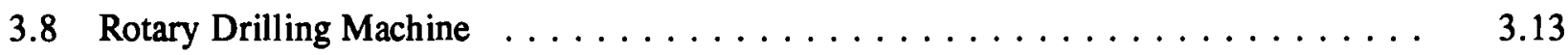

3.9 Typical Soil Jetting Device $\ldots \ldots \ldots \ldots \ldots \ldots \ldots \ldots \ldots \ldots \ldots \ldots \ldots$

3.10 Typical Horizontal Boring Machine $\ldots \ldots \ldots \ldots \ldots \ldots \ldots \ldots \ldots \ldots$

3.11 Typical Microtunneling Machine $\ldots \ldots \ldots \ldots \ldots \ldots \ldots \ldots \ldots \ldots \ldots$

3.12 Longwall Mining Machine $\ldots \ldots \ldots \ldots \ldots \ldots \ldots \ldots \ldots$ 


\section{Tables}

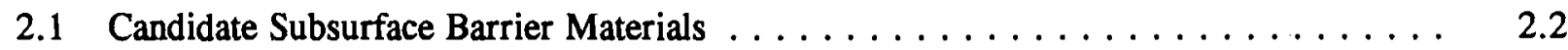

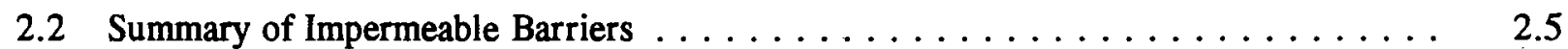

3.1 Excavation Equipment Used for Slurry Trench Construction . . . . . . . . . 3.5

3.2 Summary of Drilling Technologies $\ldots \ldots \ldots \ldots \ldots$

4.1 Types of Borehole Samplers $\ldots \ldots \ldots \ldots \ldots \ldots \ldots \ldots \ldots \ldots \ldots \ldots \ldots$

4.2 Water Sampling Devices for Monitoring Wells $\ldots \ldots \ldots \ldots \ldots$ 
, 


\title{
List of Terms
}

\author{
AEA Atomic Energy Act \\ CERCLA Comprehensive Environmental Response, Conservation, and Liability Act \\ DOE U.S. Department of Energy \\ EPA U.S. Environmental Protection Agency \\ RCRA Resource Conservation and Recovery Act
}



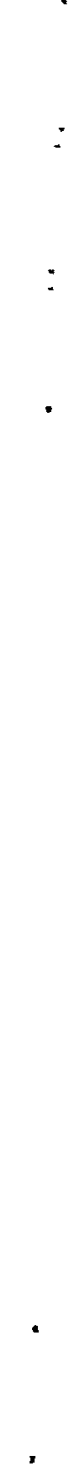


\subsection{Introduction to Barrier Technology}

This section provides a brief overview of conventional barrier technologies (e.g., impermeable physical barriers, such as caps and slurry walls) and their applications. This overview is intended to provide perspective on subsurface permeable barriers, a new and undeveloped subset of barrier technology.

The use of barriers is one of the most common and cost-effective methods for the disposal of waste materials. Wastes disposed under the Resource Conservation and Recovery Act (RCRA), for example, are disposed in excavations protected with various liner materials to prevent or minimize the escape of waste leachates to the groundwater. Waste disposal sites under RCRA are closed using a barrier cap constructed of low-permeability materials. A cap is intended to provide a barrier to the ingress of water, thereby limiting the quantity of leachate that may form. Wastes disposed under the Atomic Energy Act (AEA) also employ barrier materials intended to ensure safe containment while the radioactive constituents decay to safe levels. Barrier materials employed for disposal of AEA wastes include special packaging materials and thick covers of native soil. Barriers are also frequently used as part of remedial actions conducted at existing waste sites regulated under the Comprehensive Environmental Response, Conservation, and Liability Act (CERCLA). Barrier types that have been employed under CERCLA include caps installed over the waste sites and low-permeability structures around contaminant plumes (Koerner 1986).

The purpose of a barrier is to contain or limit the spread of contamination to within the confines of the waste disposal zone. Several naturally occurring mechanisms that induce migration of contaminants must be addressed in designing an effective barrier system. These include 1) penetration by burrowing animals and plant roots, 2) erosion by the wind and surface water run-off, 3) infiltration, advection, and dispersion of subsurface water, and 4) diffusion (Wing and Gee 1990). Infiltration, advection, and dispersion mobilize contaminants as a consequence of the gravitationally induced movement of both unsaturated and saturated zone groundwater. The moving groundwater carries contaminants at rates that depend on the properties of the individual contaminants and the geochemical and hydrogeological properties of the local soil. Diffusion involves the molecular or ionic migration of contaminants through materials. Diffusion in the soil air space can be a significant mechanism for dispersal of contaminants, but only for gaseous species. Diffusion in the water-filled pores or capillaries of the soil is relatively slow, but can be a significant factor when surface water infiltration is essentially precluded (Campbell et al. 1990).

\subsection{Barrier Technology Overview}

Various barrier technologies have been developed or are under development that show promise for counteracting the four general waste spreading mechanisms (see Section 1.0). These technologies may employ physical, thermal, chemical, and/or biological methods. A barrier system with several barrier technologies may be necessary to provide adequate protection, especially in cases of highly variable waste and soil conditions. 
Caps or covers are examples of physical barrier technologies that may address several of the dispersive mechanisms. Caps and covers apply to waste sites in the unsaturated zone. Circulating air barriers are another physical barrier type and are created by flowing warm, dry air in the unsaturated zone under a waste disposal site (K\&M/BDM 1992). The air draws moisture from the ground, thus minimizing the contaminant-mobilizing effects of infiltration, advection, and dispersion. The exhaust air is treated before its release to the atmosphere.

Freeze barriers are examples of thermal barriers. Freeze barriers are created by inserting pipes into or around buried waste. The circulation of cryogenic fluids through the pipes may create a block, wall, or basin of ice as water in the ground freezes. Contaminants are immobilized within the ice barrier.

Examples of chemical and physicochemical barriers are described in The Handbook on In Situ Treatment of Hazardous Waste-Contaminated Soils (EPA 1990). Various U.S. Environmental Protection Agency (EPA) programs tested the effectiveness of layers of coal and limestone in treating municipal waste leachate spiked with phenol and dichlorobenzene. Coal was found to be effective for sorbing organic contaminants, and limestone was found to be effective for increasing $\mathrm{pH}$, thereby precipitating many heavy metal cations.

An example of a barrier design formed by biological processes is described by Carpenter and Johnson (1990). They proposed creating a highly reducing environment at the base of a tailings pile. The chemically reducing barrier can be formed by the bacterial metabolism of an injected carbonaceous substrate. The sulfides and bisulfides that result effectively reduce and precipitate certain metal anions, such as uranates, selenates, and arsenates.

\subsection{Scope of Report}

This report focuses on a subset of overall waste site barrier technologies, specifically, subsurface barrier technologies that are potentially applicable to existing waste disposal sites. This subset does not include technologies applicable to waste disposal sites under construction, technologies used for covering or capping filled waste disposal sites, and technologies that produce essentially impermeable subsurface barriers around and/or under waste sites. However, some of the materials and equipment used to emplace impermeable barriers are applicable to the emplacement of permeable barriers as described in this report (Corbitt 1990).

Section 2 of this report briefly describes candidate subsurface permeable barriers. Section 3 discusses methods of emplacing these barriers. Section 4 describes the methods to monitor the quality of emplacement and subsequent subsurface barrier performance. References are cited in Section 5.

This report was prepared in support of investigations into innovative barrier technologies under the U.S. Department of Energy (DOE) In Situ Remediation Integrated Program. The subsurface barrier technologies described in this report are largely conceptual or represent extrapolation of existing technology to applications around and under buried waste sites. 


\subsection{Subsurface Permeable Barriers}

Subsurface permeable barriers can be created in situ by emplacing soluble or insoluble materials into the soil around and/or under a contaminated waste site. The chemicals used must reduce the rate of migration of contaminants of concern through the barrier zone (EPA 1990).

Subsurface permeable barrier technology is largely unproven, but shows significant promise of temporarily or permanently remediating contaminated waste sites. A potential advantage of this technology over subsurface impermeable barrier technology is less rigorous installation requirements. For illustration, an impermeable barrier must stop the flow of contaminated groundwater. This may require effective sealing between each individual segment of the installed barrier and between the barrier and the aquitard. Achieving a water-tight seal under subsurface conditions is difficult, especially in unsaturated zone applications where water advection rates are very low. Low water flow rates may facilitate relatively high flow through barrier joints and other imperfections. Methods to adequately identify and repair leaks in a subsurface environment have yet to be developed. Subsurface permeable barriers, in contrast, are designed to allow water to flow through the barrier. Most subsurface permeable barriers will not cause the buildup of a significant hydraulic head behind them, which otherwise could accelerate flow of water through cracks and areas of high hydraulic conductivity. An imperfectly installed permeable barrier will result in diminished barrier performance, but probably significantly less than impermeable barriers.

\subsection{Materials for Creating Permeable Barriers}

Selecting materials for creating effective permeable barriers requires consideration of the contaminants of concern, their concentrations, their speciation, and the physical and chemical conditions of the soil. The contaminants of concern, their concentrations, and their speciation are important for identifying potential chemical additives that may effectively reduce migration rates of the individual contaminants to acceptable levels. Reducing migration rates can occur by several mechanisms, including precipitation, adsorption, ion exchange, biodegradation, biofixation, and chemical degradation (e.g., hydrolysis). The function of a permeable barrier is to induce or enhance one or more of these mechanisms.

Precipitation can be promoted using other mechanisms, e.g., reducing temperature, or changing the hydrogen-ion activity $(\mathrm{pH})$ and/or oxidation potential $(\mathrm{Eh})$ of the groundwater to form less soluble species. The resulting precipitants are generally immobilized on the surface of soil particles or as a consequence of the filtering action that occurs within the soil matrix. Chemicals capable of changing $\mathrm{pH}$ include acids, bases, and salts that are strongly buffering. Calcium carbonate (limestone), for example, can buffer groundwater to a $\mathrm{pH}$ of greater than 10. Martin et al. (1986) induced precipitation by modifying the Eh of uranium tailings' leachate by injecting sodium sulfide.

Adsorption and ion exchange remove chemical contaminants from solution without changing the speciation of the contaminant. Various forms of carbon such as coal and activated carbon are effective 
in removing dissolved organic materials and certain anions such as iodide. Certain clays and minerals are effective in sorbing and/or exchanging metal cations. Synthetic resins and minerals can be designed for selective removal of ionic contaminants (Nyer 1992).

Biodegradation and associated biofixation are biological processes that require a carbon source and nutrients, e.g. nitrogen, phosphorous, and potassium. Certain types of bacteria and fungi can metabolize organic compounds. Others can co-metabolize highly toxic organic compounds such as chlorinated hydrocarbons. However, these highly toxic compounds are difficult to metabolize when they are the only source of organic carbon. Formation of a microbial community creates a carbon-rich biomass and, in some cases, a strongly reducing environment. As a result, these microorganisms may induce the precipitation of metals and create conditions that enhance the adsorption of organic contaminants and metals.

Recently in a permeable barrier field demonstration, chemical degradation has been shown to reduce the migration of chlorinated hydrocarbons (Gillham and O'Hannesin 1992; O'Hannesin and Gillham 1992). In this process, iron metal is used to reduce chlorinated hydrocarbons into innocuous hydrocarbons and chloride ions. When the hydrocarbons subsequently encounter oxygenated water, they will be oxidized to carbon dioxide and water.

A short list of materials that could induce precipitation, sorption, ion exchange, biodegradation, and/or biofixation are listed in Table 2.1.

Table 2.1. Candidate Subsurface Barrier Materials

\begin{tabular}{|c|l|l|}
\hline $\begin{array}{c}\text { Barrier } \\
\text { Objective }\end{array}$ & \multicolumn{1}{|c|}{$\begin{array}{c}\text { Material } \\
\text { Classification }\end{array}$} & \multicolumn{1}{|c|}{$\begin{array}{c}\text { Example } \\
\text { Materials }\end{array}$} \\
\hline \hline \multirow{3}{*}{ Precipitation } & $\begin{array}{l}\text { Soluble pH adjusters } \\
\text { Insoluble pH adjusters } \\
\text { Soluble Eh adjusters } \\
\text { Insoluble Eh adjusters } \\
\text { Mineral formers }\end{array}$ & $\begin{array}{l}\text { Acids, bases } \\
\text { Limestone, fly ash } \\
\text { Ferrous salts } \\
\text { Blast furnace slag } \\
\text { Phosphate salts }\end{array}$ \\
\hline $\begin{array}{c}\text { Sorption and } \\
\text { ion exchange }\end{array}$ & $\begin{array}{l}\text { Natural organic sorbents } \\
\text { Synthetic organic sorbents }\end{array}$ & $\begin{array}{l}\text { Biomass } \\
\text { Activated carbon } \\
\text { Ion-exchange resins }\end{array}$ \\
\hline $\begin{array}{l}\text { Biodegradation } \\
\text { and biofixation }\end{array}$ & Microorganisms & Clays, zeolites \\
\hline
\end{tabular}




\subsection{Geological, Hydrological, and Geochemical Factors}

The physical and chemical characteristics of the soil and groundwater in which the permeable barrier will be emplaced must be considered carefully when selecting barrier materials. Soils have widely varying physical properties. Average particle diameters range from microns to centimeters. Cobbles, boulders, cemented soils, and bedrock may be encountered. Some soils exhibit large horizontal and vertical heterogeneities in particle sizes and degree of consolidation. The presence of large rocks and heterogeneities can present mechanical challenges for emplacing permeable barriers.

Hydraulic conductivity (which is related to particle size) is an important factor in assessing the feasibility of subsurface barriers created by injecting soluble chemicals into the ground. Hydraulic conductivity and the pressure required for injecting the barrier-forming material are directly proportional to the rate at which the injected material will flow through the soil, according to Darcy's Law (Driscoll 1986). Hydraulic conductivities can vary by several orders of magnitude at a given site when significant soil heterogeneities are present. For injection-based barrier technologies, low hydraulic conductivities and significant variability in hydraulic conductivity can cause low injection rates and uneven distribution of injected fluids, thus creating an ineffective barrier. Variable hydraulic conductivity may also lead to groundwater channeling, which may result in rapid exhaustion of the barrier chemicals in one location while the bulk of barrier chemicals in other locations are largely unused (Maidment 1993).

The soil geochemistry is another important consideration. Soils possess natural geochemical properties that inhibit migration rates of certain contaminants. Nearly all soils contain organic carbon, ranging from approximately $0.05 \mathrm{wt} \%$ to $0.20 \mathrm{wt} \%$ (Buol et al. 1989). Naturally occurring organic carbon adsorbs organic compounds from the groundwater as does the carbon additives used for creating barriers (EPA 1990). Thus, the greatest benefit of carbon additives will be derived in soils with low organic carbon contents.

Most soils can sequester heavy metal cations through ion exchange or surface complexation. This ability is generally represented by the soil's cation-exchange capacity. Soils with a low cationexchange capacity may benefit most by barrier additives that have high metal cation sorption or exchange capacities. Thoughtful evaluation of the cation sorbers/exchangers to be applied in groundwater is required to ensure that the cation sorber/exchanger remains effective in the presence of major ambient cations with high selectivity.

Soils and associated groundwater also exhibit a wide range of $\mathrm{pH}$ and $\mathrm{Eh}$ values. Most soils fall within a pH range of 4.0 to 9.0 and an Eh range of -300 to $700 \mathrm{mV}$ (Baas-Becking et al. 1960). Some soils with high buffering capacities will counteract the additives used to adjust $\mathrm{pH}$ and Eh. Certain additives may also intentionally or unintentionally change the microbiological population of soil which may affect the local geochemistry and effectiveness of the barrier.

\subsection{Permeable Barrier Types}

Two basic types of permeable barrier technologies exist: 1) those that apply to contamination in the vadose zone, and 2) those that apply to mobile contamination in the saturated zone. Vadose zone 
technologies are largely conceptual and undeveloped. These technologies include both vertical and horizontal barrier components. Horizontal barrier components are emplaced under the waste area to intercept meteoric water. Vertical barrier components that intersect the horizontal component may be necessary if horizontal dispersion and/or diffusion of contaminants are occurring (EPA 1990).

The vadose zone barrier should be designed with a higher matric potential than the native soil above it if possible. The higher matric potential will help distribute water more evenly in the barrier and may be effective for minimizing the potential for channeling. Higher matric potentials can usually be created by adding barrier materials as very fine solids. Sufficient permeability (hydraulic conductivity) of the barrier must be assured, however, to avoid perching of water on the barrier, resulting in lateral flow without penetrating the barrier.

Saturated zone barriers may be installed in a vertical configuration downgradient of the contaminated groundwater plume. Installing the barrier around the entire plume is unnecessary because the permeability of the barrier ensures that groundwater flow paths will not be significantly altered, i.e., forced around the barrier. Horizontal barriers under the water table may also be considered if significant vertical migration is occurring. The saturated hydraulic conductivity of the barrier materials should be higher than that of the soils, if possible. This will help ensure the groundwater contacts the barrier additives if imperfect mixing of soil and additives occurs. In some cases it will be unnecessary to key the barrier to the aquitard. This applies when limited vertical dispersion of contaminants in the groundwater has occurred. In those cases it is only necessary to emplace the vertical barrier a short distance below the maximum depth of contamination.

\subsection{Composite Barriers}

A potential modification of the permeable barrier concept is to add impermeable barrier components to the design. For example, impermeable barriers constructed on the edges of a groundwater plume will direct the plume toward a downgradient permeable barrier. If the permeable barrier is engineered for ease of replacement, the combined barrier concept offers potential for long-term effectiveness and lower maintenance costs. Impermeable barrier components could include the following developed technologies:

- sheet piling

- grout curtains

- $\quad$ slurry walls

- freeze walls.

Table 2.2 briefly summarizes these barrier types, methods of installation, and important limitations (WHC 1991, 1993). 
Table 2.2. Summary of Impermeable Barriers

\begin{tabular}{|c|c|c|c|}
\hline Type & Definition & Installation Method & Important Limitations \\
\hline Sheet piling & Interlocking steel panels & $\begin{array}{l}\text { Panels are driven } \\
\text { vertically into the } \\
\text { subsurface. }\end{array}$ & $\begin{array}{l}\text { Large rocks in the } \\
\text { subsurface may cause } \\
\text { deflection of the panels } \\
\text { and, therefore, won't } \\
\text { interlock properly. }\end{array}$ \\
\hline Grout curtains & $\begin{array}{l}\text { A series of intersecting grout- } \\
\text { filled "posts" in the subsurface }\end{array}$ & $\begin{array}{l}\text { Grout is pressure injected } \\
\text { into drilled boreholes to } \\
\text { form "posts." }\end{array}$ & $\begin{array}{l}\text { Gaps may occur between } \\
\text { the posts. }\end{array}$ \\
\hline Slurry walls & $\begin{array}{l}\text { Typically cement and bentonite } \\
\text { or soil and bentonite admixtures } \\
\text { to form a low permeability wall } \\
\text { in the subsurface }\end{array}$ & $\begin{array}{l}\text { Deep soil mixing or } \\
\text { vertical trenching with } \\
\text { excavating equipment } \\
\text { (i.e., backhoe, clamshell) } \\
\text { and backfill with low } \\
\text { permeability slurry. }\end{array}$ & $\begin{array}{l}\text { No unique limitations. All } \\
\text { methods must be matched } \\
\text { to site-specific conditions } \\
\text { of soil characteristics (i.e., } \\
\text { grain size) and chemical } \\
\text { compatibility. }\end{array}$ \\
\hline Freeze walls & $\begin{array}{l}\text { Freezing the soil particles and } \\
\text { interstitial water to decrease } \\
\text { permeability }\end{array}$ & $\begin{array}{l}\text { A refrigerant (i.e., brine) } \\
\text { is circulated through a } \\
\text { piping network embedded } \\
\text { in the subsurface. }\end{array}$ & $\begin{array}{l}\text { Relatively high capital and } \\
\text { operating and maintenance } \\
\text { costs compared to other } \\
\text { methods. }\end{array}$ \\
\hline
\end{tabular}





\subsection{Emplacement Methods}

Materials for creating permeable barriers can be emplaced using one of three basic methods: injection, in situ mechanical mixing, or excavation/insertion.

Injection involves placing dissolved reagents or colloidal suspensions into the soil at elevated pressures. Injection is not applicable when the barrier admixture is composed of fairly large particles because of the filtering action of the soil particles, which will block the soil pores near the point of injection. Injection will not normally create contaminated spoils, but if injection occurs in contaminated soils, contaminants may be mobilized by the injection fluid.

In situ mechanical mixing entails the physical blending of the soil and the barrier material underground. The combination of loosening the soil by the mixing action and the volume occupied by the barrier material results in a displaced soil volume requiring disposal. If the barrier is formed in a contaminated zone, the displaced soils are also likely to be contaminated.

Excavation/insertion entails removing a volume of soil and adding barrier materials to the void space created. This method will also generate contaminated spoils if the barrier is installed in a contaminated zone.

These three basic emplacement methods apply to the installation of both vertical and horizontal barriers (see Section 2.3). Excavation/insertion is the only well-developed emplacement technology. This section identifies and discusses individual technologies that may be applicable for installing vertical and horizontal permeable barriers. A key consideration for all types of drilling must be the flexibility and strength of the drilling and casing materials.

\subsection{Vertical Permeable Barrier Emplacement Technologies}

Vertical permeable barriers may be created in the unsaturated and saturated zones using the same or similar emplacement technologies. The removal of soil to create a barrier wall can be accomplished using conventional excavating equipment such as backhoes, clamshells, and draglines, or by using equipment capable of creating overlapping holes, such as drills, augers, and jets. The overlap of holes may not be required if barrier-forming materials are injected into the holes. In this case, the penetration diameter of the aqueous barrier-forming materials is designed to overlap with the penetration diameters in adjacent holes.

\subsubsection{Trenching/Backfilling}

Cohesive soils are amenable to deep trenching without the use of shoring or other techniques to prevent collapse or creep of the excavated wall. Open trenches up to $18-\mathrm{m}$ deep can be created using backhoes under ideal soil conditions. Deeper excavations may be possible using clamshell and dragline excavators (Figures 3.1 and 3.2). To minimize the potential for wall collapse, soluble cementing agents or biodegradable polymers may be injected into the barrier zone before excavation. The faces 


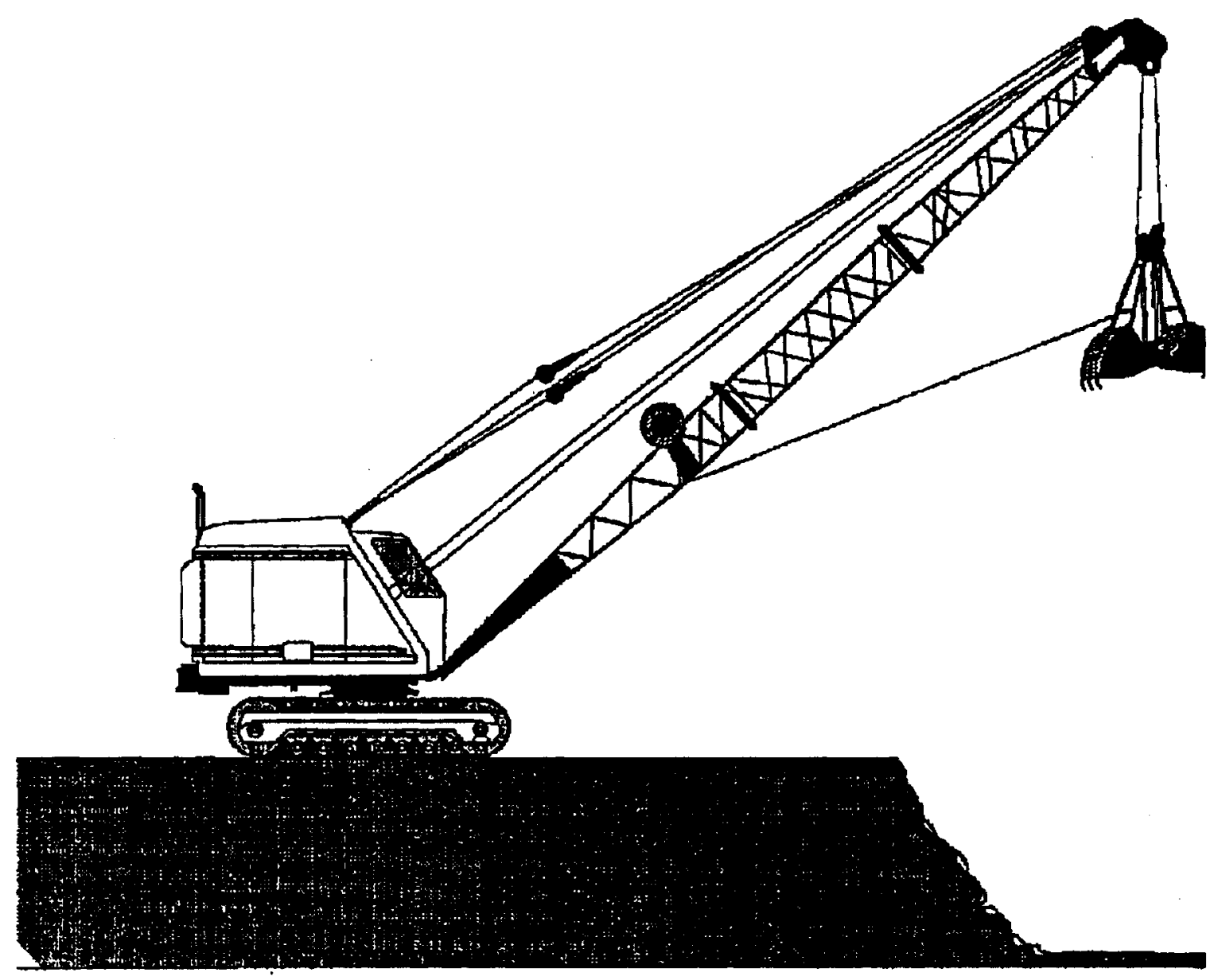

Figure 3.1. Clamshell Excavator

of excavated walls may also be sprayed with similar solutions to enhance the physical stability of the wall before emplacing the barrier materials. Protection against the weather may be required in some cases to prevent wall erosion and sloughing (ASTM 1992).

Backfilling the trench must be carefully constructed to avoid dislodging soil from the excavation face. Dislodged soil may compromise the effectiveness of the barrier. Loading the trench using a slide or other technique that prevents contact with the excavation face may be necessary.

Shoring can be used with unstable soil. The shoring may need to be removed after or during the emplacement of barrier materials. When the barrier is installed above the water table, the moisture content of barrier materials should be controlled to optimize self-compaction and material spreading in the trench. A poorly compacted barrier material may allow excavation face collapse, which may compromise barrier effectiveness. When the barrier wall is installed below the water table, the trench may need to be dewatered if the particle sizes of the barrier materials vary widely. Particle settling rates 


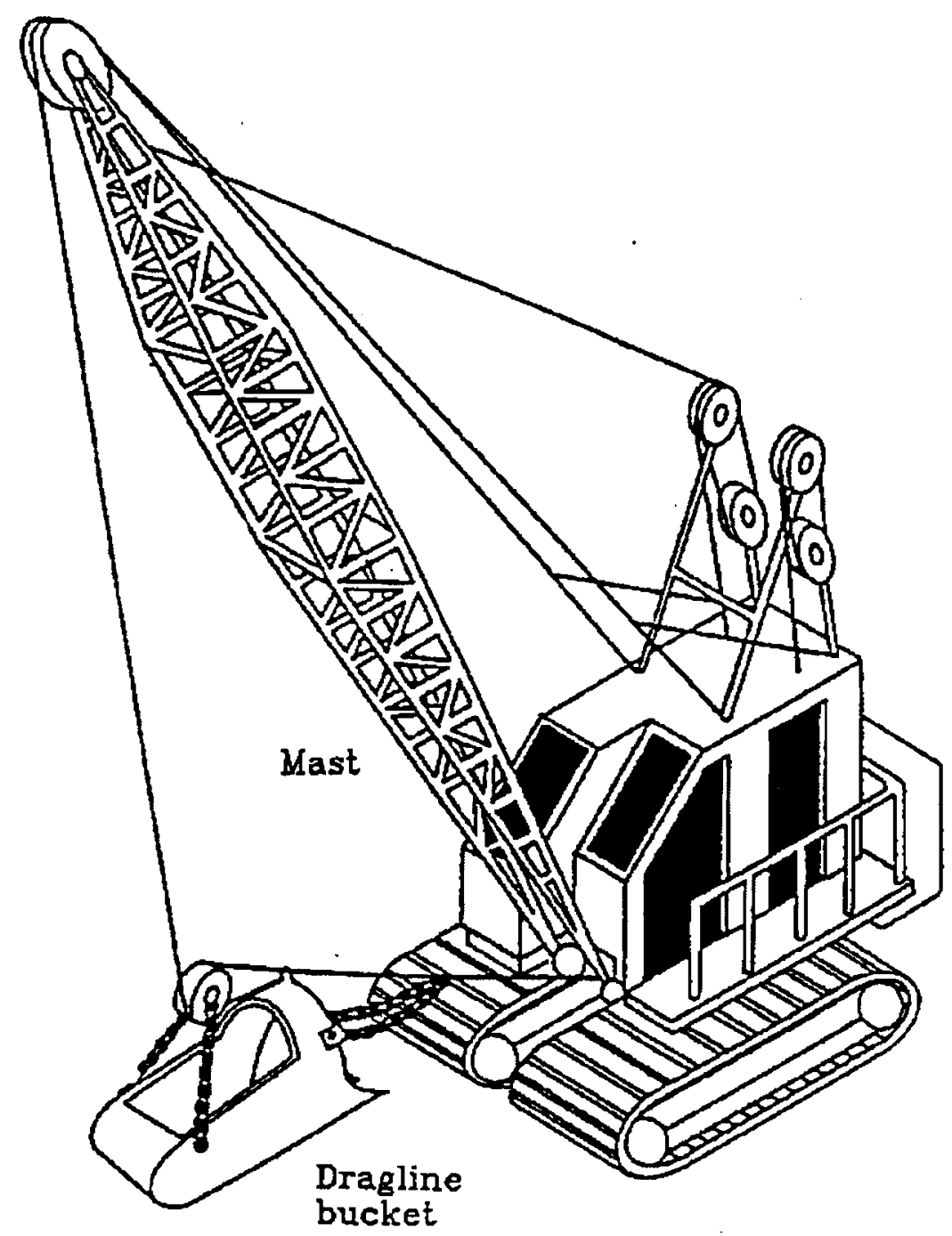

Figure 3.2. Dragline Excavator

diminish as a function of the square of the diameter of the particle in accordance to Stoke's Law. This can cause significant segregation of barrier materials and may reduce barrier performance. An alternative to trench pumping is the controlled injection of the barrier materials as a thick slurry into the base of the trench. The slurry will displace the water with minimal mixing.

\subsubsection{Slurry Trenching}

Slurry trenching is generally applicable in cases of relatively shallow groundwater. It is an established technology for creating impermeable barriers (Figure 3.3). Slurry trenching technology may also be used to create a permeable barrier. Very little documentation exists on using slurry trenching for developing permeable treatment beds, however (EPA 1990). 


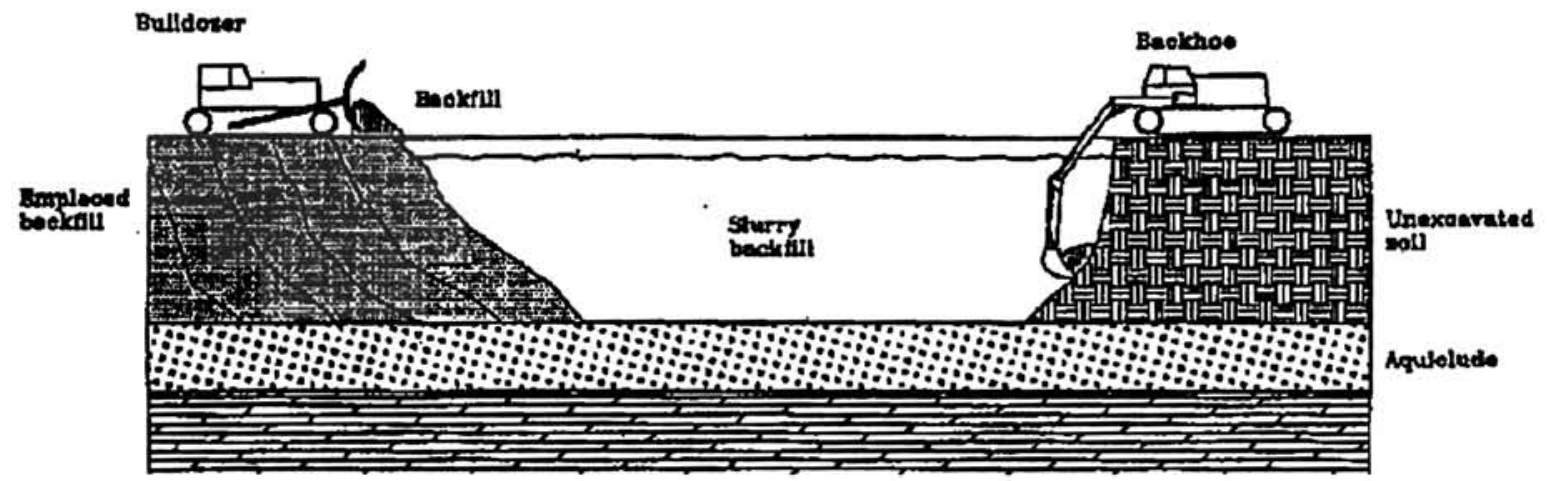

Figure 3.3. Slurry Trenching

In slurry trench construction, a trench is excavated while keeping it filled with a slurry that has a slightly higher specific gravity than water. This creates a hydrostatic head to stabilize the side of the trench and prevent collapse. Sheet piling or shoring may be needed to prevent collapse of sandy soils. As each lift of soil is removed, a comparable amount of slurry is added. Bentonite clay and/or cement slurries are commonly used when creating a slurry wall. Residues of these or similar materials left on the sides of the trench may act as a low-permeability barrier and defeat the goal of a permeable barrier. To allow water to flow through the barrier, it may be necessary to use a nonsealing slurry or biodegradable slurry.

Backhoes, clamshells, and draglines are generally used in slurry trenching. A summary of the capabilities of equipment used for slurry trenching is provided in Table 3.1.

The materials selected for creating the barrier will be placed at, or pumped to, the bottom of the trench as the slurry is forced or pumped out. The trench wall will then be backfilled with native soil once the required barrier elevation is reached. As in the trenching/backfilling technology, any contaminated soil or slurry removed from the trench will have to be treated and/or disposed of as a contaminated waste.

\subsubsection{Vertical Drilling and Injection Techniques}

The selection of a vertical drilling method is generally based on the required well depth and the anticipated subsurface geologic and hydrologic characteristics. Holes less than $30-\mathrm{m}$ deep are usually augured, driven, or jetted. Holes greater than 30-m deep are usually created by rotary, cable-tool, or sonic drilling, or by special application jetting.

Angled holes can also be created by these methods. This capability introduces the prospect of creating a barrier by intersecting the angled holes below the waste site, thus preventing the need for using a separate horizontal barrier technology. Table 3.2 summarizes various drilling methods and the geologic and hydrologic conditions under which they apply. After drilling is completed, barrierforming solutions can be injected into the soil formation through the drilled face of the hole or through slots formed in casings. Natural gravity or pumping can provide the pressure required to force the 
Table 3.1. Excavation Equipment Used for Slurry Trench Construction (adapted from EPA 1984)

\begin{tabular}{|c|c|c|c|}
\hline Type & $\begin{array}{l}\text { Trench } \\
\text { Width } \\
\text { (m) }\end{array}$ & $\begin{array}{l}\text { Trench } \\
\text { Depth } \\
\text { (m) }\end{array}$ & Comments \\
\hline Standard backhoe & $0.3-1.5$ & 15 & Least costly excavation method \\
\hline Modified backhoe & $0.6-1.5$ & 24 & $\begin{array}{l}\text { Uses an extended dipper stick, } \\
\text { modified engine \& counter-weighted } \\
\text { frame; is also rapid and relatively low } \\
\text { cost }\end{array}$ \\
\hline Clamshell & $0.3-1.5$ & 46 & $\begin{array}{l}\text { Attached to a kelly bar or crane; } \\
\text { needs } \geq 18 \text {-ton crane; can be } \\
\text { mechanical or hydraulic }\end{array}$ \\
\hline Dragline & $1.2-3$ & 37 & $\begin{array}{l}\text { Primarily used for wide, deep soil } \\
\text { bentonite trenches }\end{array}$ \\
\hline $\begin{array}{l}\text { Rotary drill, } \\
\text { percussion drill, } \\
\text { or large chisel }\end{array}$ & - & -- & $\begin{array}{l}\text { Used to break up boulders and to key } \\
\text { into hard rock aquicludes. Can slow } \\
\text { construction and result in irregular } \\
\text { trench walls }\end{array}$ \\
\hline
\end{tabular}

solution into the soil. Shallow, augured, or bored holes may be overlapped under stable soil conditions, allowing a continuous barrier wall to be formed without relying on injection of solutions.

\subsubsection{Boring (Earth Augering)}

Earth-augering machines of various sizes and designs are used to drill shallow boreholes in unconsolidated sediments. Three principal types are commonly used: 1) rotary-bucket augers, 2) solid-stem augers, and 3) hollow-stem augers. Figures 3.4 and 3.5 show a rotary-bucket auger and a hollow-stem auger, respectively.

3.1.3.1.1. Rotary-Bucket Auger. The rotary-bucket auger uses a large cylindrical steel bucket with a cutting edge on the bottom. The bucket is filled by rotating it in the hole. It is then hoisted to the surface and emptied. Reamers attached to the outer face of the bucket can enlarge the holes to diameters exceeding the auger diameter (Driscoll 1986).

Wells more than 76-m deep have been drilled under stable soil conditions using bucket augers. Well depths of 15 to $27 \mathrm{~m}$ are more common. Bucket augers range in diameter from 46 to $122 \mathrm{~cm}$. When augering in dense formations, tungsten carbide inserts or special hardened teeth are fixed to the cutting blades on the bottom of the bucket. This technology is usually used to create large-diameter boreholes in clay formations that allow insertion of casing without the hole collapsing. Drilling in sand below the water table is difficult but not impossible. Large quantities of water or drilling fluid may be needed when drilling in permeable sands in the unsaturated zone. The maximum demand for water may only last for a few hours because drilling may proceed rapidly under favorable conditions. Fluid 
Table 3.2. Summary of Drilling Technologies (adapted from EPA 1985)

\begin{tabular}{|c|c|c|c|c|c|c|}
\hline \multicolumn{2}{|c|}{18 Method } & \multicolumn{3}{|c|}{ Applications } & \multirow[b]{2}{*}{ Casing/Sereen } & \multirow[b]{2}{*}{ Comments } \\
\hline Basic & Variations & Geologic Material & Max. & Wepth & & \\
\hline \multirow[b]{2}{*}{ Boring } & $\begin{array}{l}\text { Rotary auger } \\
\text { bucket }\end{array}$ & $\begin{array}{l}\text { Soft soils without } \\
\text { excess boulders }\end{array}$ & 122 & 27 & $\begin{array}{l}\text { Driven after } \\
\text { hole opened }\end{array}$ & $\begin{array}{l}\text { Typically limited to } 61-\mathrm{cm} \\
\text { diameter wells or less }\end{array}$ \\
\hline & Spiral auger & $\begin{array}{l}\text { Soft soils without } \\
\text { excess sand and } \\
\text { water, no boulders }\end{array}$ & 15 & 27 & $\begin{array}{l}\text { Driven after } \\
\text { hole opened }\end{array}$ & $\begin{array}{l}\text { Cannot be used below water } \\
\text { table, must be used in } \\
\text { combination with other } \\
\text { techniques }\end{array}$ \\
\hline \multirow{4}{*}{$\begin{array}{l}\text { Rotary } \\
\text { drilling }\end{array}$} & $\begin{array}{l}\text { Conventional } \\
\text { hydraulic }\end{array}$ & Any type & - & - & $\begin{array}{l}\text { Placed after } \\
\text { hole opened }\end{array}$ & $\begin{array}{l}\text { Typically used for deep } \\
\text { wells, quickest drilling } \\
\text { method }\end{array}$ \\
\hline & Reverse hydraulic & $\begin{array}{l}\text { Any type, boulders } \\
\text { may be a problem }\end{array}$ & 152 & - & $\begin{array}{l}\text { Placed after } \\
\text { hole opened }\end{array}$ & $\begin{array}{l}\text { Requires large quantities of } \\
\text { water }\end{array}$ \\
\hline & Air rotary & Any type & 30 & - & $\begin{array}{l}\text { Placed after } \\
\text { hole opened }\end{array}$ & Very. fast method \\
\hline & $\begin{array}{l}\text { Air rotary with } \\
\text { pneumatic hammer }\end{array}$ & Any type & 20 & - & $\begin{array}{l}\text { Placed after } \\
\text { hole opened }\end{array}$ & \\
\hline $\begin{array}{l}\text { Sonic } \\
\text { drilling }\end{array}$ & $\begin{array}{l}\text { Conventional } \\
\text { hydraulic }\end{array}$ & Slant holes/vertical & $\overline{-}$ & $\overline{--}$ & $\begin{array}{l}\text { Placed after } \\
\text { hole opened }\end{array}$ & $\begin{array}{l}\text { Currently being tested for } \\
\text { slant drilling }\end{array}$ \\
\hline \multirow{2}{*}{ Cable tool } & Conventional & Any type & - & - & $\begin{array}{l}\text { Driven during } \\
\text { or after hole } \\
\text { opened }\end{array}$ & $\begin{array}{l}\text { Typically used for deep } \\
\text { wells, provide ability to } \\
\text { closely monitor and log well }\end{array}$ \\
\hline & $\begin{array}{l}\text { California stove } \\
\text { pipe }\end{array}$ & Any type & - & - & $\begin{array}{l}\text { Pushed with } \\
\text { jacks as hole } \\
\text { opened }\end{array}$ & $\begin{array}{l}\text { Quicker and less expensive } \\
\text { than conventional cable tool }\end{array}$ \\
\hline \multirow{5}{*}{ Jetting } & Self jetting & $\begin{array}{l}\text { Soft soils free of } \\
\text { boulders }\end{array}$ & 20 & 15 & $\begin{array}{l}\text { Driven as hole } \\
\text { opened }\end{array}$ & $\begin{array}{l}\text { Jetted wells require less } \\
\text { development }\end{array}$ \\
\hline & Wellpoint/riser unit & $\begin{array}{l}\text { Soft soils free of } \\
\text { boulders }\end{array}$ & 20 & 15 & $\begin{array}{l}\text { Driven as hole } \\
\text { opened }\end{array}$ & $\begin{array}{l}\text { Method used large quantities } \\
\text { of water }\end{array}$ \\
\hline & $\begin{array}{l}\text { Separate temporary } \\
\text { jetting pipe }\end{array}$ & $\begin{array}{l}\text { Soft soils free of } \\
\text { boulders }\end{array}$ & 20 & 31 & $\begin{array}{l}\text { Placed after } \\
\text { hole opened }\end{array}$ & \\
\hline & $\begin{array}{l}\text { Separate permanent } \\
\text { jetting pipe }\end{array}$ & $\begin{array}{l}\text { Soft soils free of } \\
\text { boulders }\end{array}$ & 20 & 31 & $\begin{array}{l}\text { Driven as hole } \\
\text { opened }\end{array}$ & \\
\hline & \begin{tabular}{|l|} 
Rotary hole- \\
puncher
\end{tabular} & $\begin{array}{l}\text { Soft soil, sandstone, } \\
\text { schist }\end{array}$ & 61 & 61 & $\begin{array}{l}\text { Driven as hole } \\
\text { opened }\end{array}$ & \\
\hline
\end{tabular}

additives such as bentonite clay or polymers may be used to control fluid loss. Cobbles and boulders create difficulties because they must be picked out of the hole individually using an orange-peel bucket, stone tongs, or a rams's horn tool (Driscoll 1986).

Unit costs reported for bucket auger drilling range from $\$ 42 / \mathrm{ft}(\$ 1.38 / \mathrm{cm})$ for a $46-\mathrm{cm}$ borehole to $\$ 58 / \mathrm{ft}(\$ 1.90 / \mathrm{cm})$ for a $122-\mathrm{cm}$ borehole (see Appendix A). 


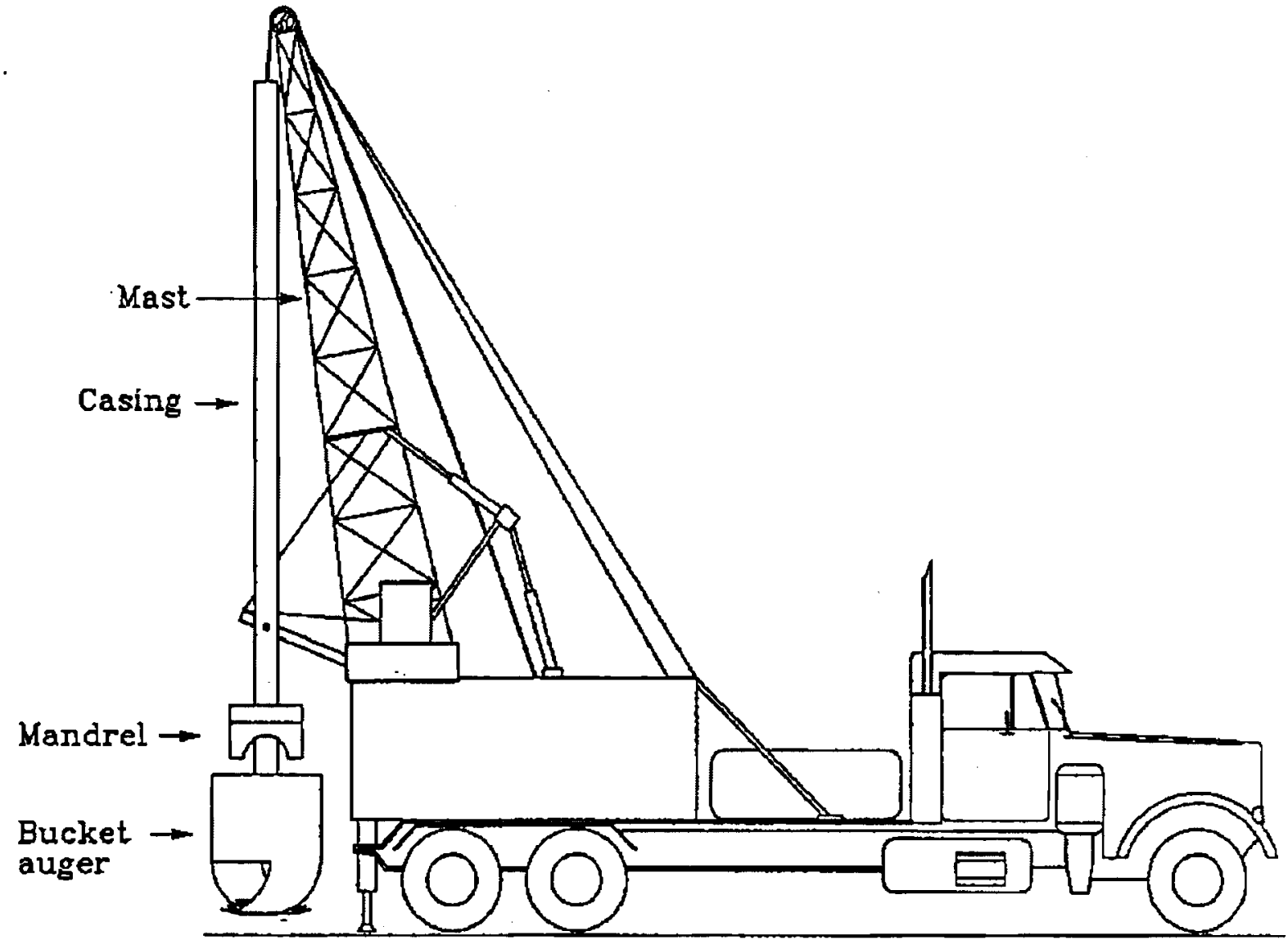

Figure 3.4. Rotary-Bucket Auguring Machine

3.1.3.1.2 Solid-Stem Augering. In solid-stem augering, the cuttings are brought to the top of the hole by flights acting as a screw conveyor. The auger can be designed for continuous flighting or as a single unit. Single-flight augers are commonly called earth augers, construction augers, or largediameter augers. With continuous-flight augers, additional sections are added until the desired augering depth is reached.

Single-flight augers diameters are commonly between 36 and $61 \mathrm{~cm}$ but diameters of up to $137 \mathrm{~cm}$ have been used. Depths of $18 \mathrm{~m}$ are achievable in stable ground using smaller-diameter augers. Hard ground, cobbles, and soft rock require the use of special hardened teeth or cutters. Solid-stem augering is ineffective in loose ground or when drilling below the water table. Continuous flight augering is used to create deep holes in stable formations. Diameters range from 15 to $36 \mathrm{~cm}$ for drilling. Augering depths commonly range from 12 to $37 \mathrm{~m}$ but holes as deep as $122 \mathrm{~m}$ have been drilled. 


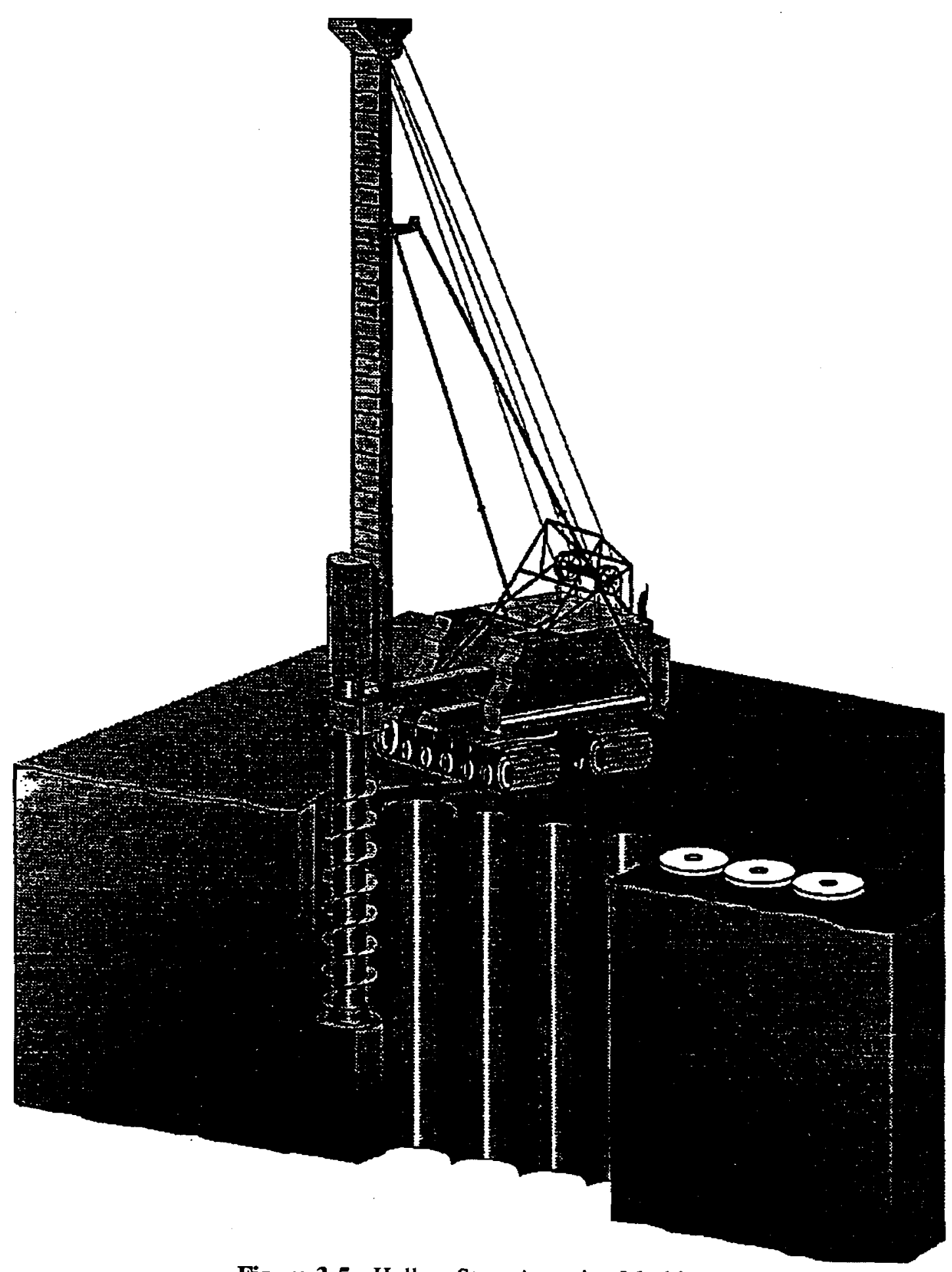

Figure 3.5. Hollow-Stem Auguring Machine 
The unit cost for solid-stem augering is approximately $\$ 48 / \mathrm{ft}(\$ 1.57 / \mathrm{cm})$ for a $20-\mathrm{cm}$ borehole (see Appendix A).

3.1.3.1.3 Hollow-Stem Augering. The flights of the hollow-stem auger are welded onto larger diameter pipe with a cutter head mounted at the bottom. Unlike the solid-stem method, drill rods or drill stems can pass through the center of the auger sections. This drilling feature allows augering in harder formations. A plug is inserted into the hollow center of the cutter head to prevent soil from rising inside the auger during the augering cycle. When augering in stiff or dense formations, the plug is not needed because only 5 to $10 \mathrm{~cm}$ of earth will rise up inside the hollow stem.

Hollow-stem auger diameters range from 15 to $56 \mathrm{~cm}$. Augering depths of up to $91 \mathrm{~m}$ have been achieved in stable formations, but depths of $37 \mathrm{~m}$ using a 16-cm-diameter auger are more common. Hollow-stem augers are more versatile than solid-stem augers in that they can be used as a temporary casing to prevent sloughing of the borehole wall. Hollow-stem augering is fast and efficient for drilling small-diameter wells to moderate depths. Large boulders will prevent penetration of the auger flights.

A disadvantage of this method is the relatively high cost of hollow-stem flight augers (Driscoll 1986). The cost of drilling an $20-\mathrm{cm}$ borehole using this method is approximately $\$ 48 / \mathrm{ft}$ $(\$ 1.57 / \mathrm{cm})$ (see Appendix A).

\subsubsection{Deep Soil Mixing}

Deep soil mixing, developed by Geo-Con Incorporated (Holden et al. 1989), delivers barrier admixtures while drilling. The system uses a set of crane-supported leads that guide a series of overlapped mixing paddles and hydraulically driven augers (Figure 3.6). Stabilizing agents or other fluids are fed through the center of each shaft as the ground is penetrated. The auger flights break the soil loose and lift it to the mixing paddles, which blend the additives with the soil. The soils and agent are remixed by additional mixing paddles on each shaft as the augers are advanced. When the augers are withdrawn, the mixing process is repeated in an adjacent, overlapping hole (see Appendix D).

Geo-Con Incorporated uses four shafts on $69-\mathrm{cm}$ centers using 91-cm-diameter augers. The four shafts treat approximately $2.5 \mathrm{~m}^{2}$ of area per stroke. Each shaft is supplied with $40,000 \mathrm{ft} \cdot \mathrm{lb}$ $(2,700 \mathrm{~N} \cdot \mathrm{m})$ of torque. The technology applies to nearly all soil types. More mixing is required for fine soil. Large obstructions such as buried concrete blocks, boulders, or pilings must be avoided. Cobbles between 31 to $36 \mathrm{~cm}$ may be augured; however at depths past $31 \mathrm{~m}$, the soil must be loose. Compact soil and frequent cobbles make deep soil mixing more difficult.

The cost of this technology is approximately $\$ 10$ to $\$ 25 / \mathrm{ft}^{2}$ ( $\$ 108$ to $\$ 269 / \mathrm{m}^{2}$ ) (WHC 1993).

\subsubsection{Cable Tool Drilling}

Cable tool drilling machines, also called percussion or "spudder" rigs (Driscoll 1986), break or crush consolidated rock into small fragments by repeatedly lifting and dropping a string of drilling tools into the borehole (Figure 3.7). The cable tool bit is usually massive and heavy to help crush all types of rock and consolidated earth materials. The drill stem gives added weight to the bit and helps maintain a straight hole when drilling in hard rock. The cable tool string and bit are rotated so that new 


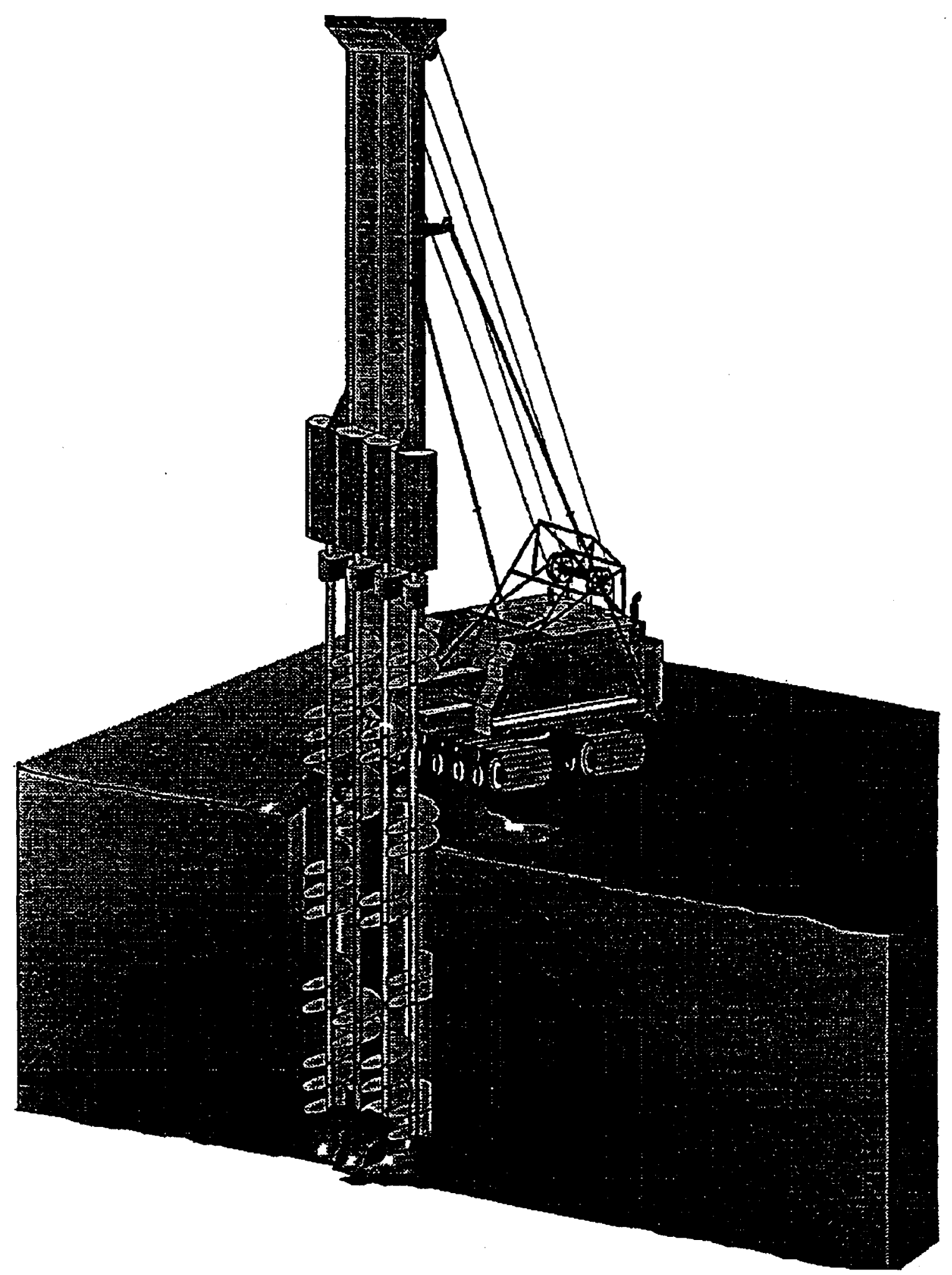

Figure 3.6. Deep Soil Mixing Machine (Geo-Con Incorporated) 


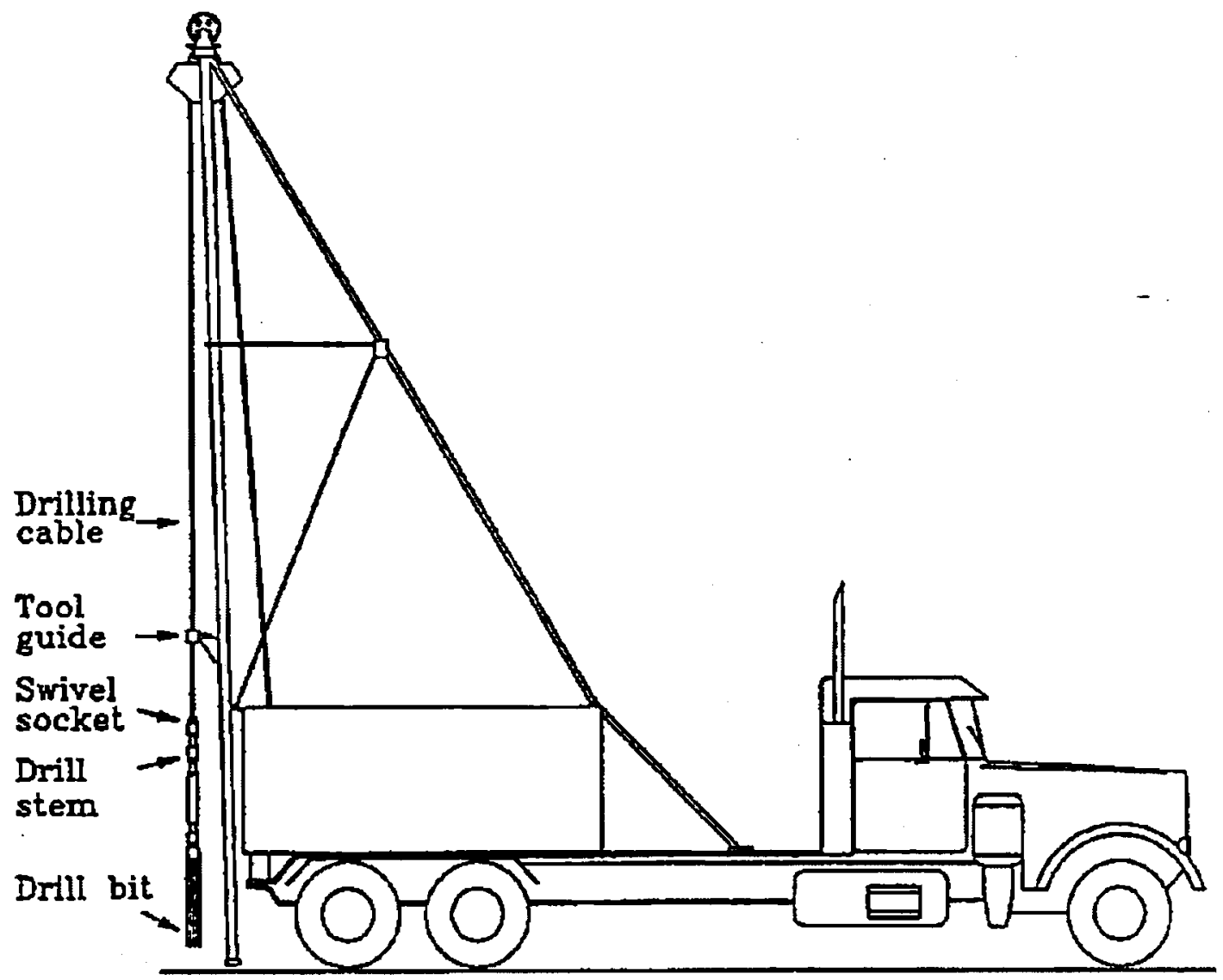

Figure 3.7. Cable Tool Drilling Machine

rock is cut on each downstroke. The tools also mix the loose and crushed particles with water to form a slurry or sludge at the bottom of the borehole. If little or no water is present in the borehole, water is added. The slurry is removed periodically using a sand pump or bailer.

Factors that affect drilling rate include the rock's resistance to fracturing and encountering dips in the rock structure. Casing must follow the drill bit closely when drilling in unconsolidated formations to prevent caving of the hole. However, casing is often not needed when drilling in consolidated formations.

The open-hole or reverse cable tool method uses heavy sand pumps or bailers operated inside the casing to cut the borehole. Holes to $61 \mathrm{~cm}$ in diameter in formations containing cobbles as large as $31 \mathrm{~m}$ can be drilled in this manner (Driscoll 1986).

Every cable tool drilling machine has certain limitations on borehole depth and diameter. In waterwell drilling, the depth capability for cable tool rigs ranges from 91 to $1524 \mathrm{~m}$ (Driscoll 1986). Smalldiameter holes may be drilled relatively deep. In large-diameter holes, the weight of the drill string and cable may become so excessive that the machine cannot function. Collapsing earth materials may further limit the effective depth for large-diameter casing because of the added friction between the 
casing and the borehole. This friction eventually prevents insertion of the casing. This friction can be reduced by adding a drilling fluid slurry around the outside of the casing during driving.

The unit cost to drill a $20-\mathrm{cm}$ borehole using the cable tool method is approximately $\$ 53 / \mathrm{ft}$ $(\$ 1.74 / \mathrm{cm})$ (see Appendix B). Drilling under potentially hazardous conditions greatly increases the cost because of the measures taken to protect operating personnel and prevent the discharge of contaminated cuttings to the environment.

\subsubsection{Rotary Drilling}

Rotary drilling uses a rotating bit and a viscous liquid or air as the drilling fluid (Figure 3.8). The limit of penetration using this method cannot be well defined because the rate at which the cuttings travel to ground surface is a complex function of drilling rate, drilling fluid density, fluid pumping rates, borehole diameter, cutting particle size, and particle density. Three rotary drilling methods commonly used are conventional-hydraulic (direct circulation), air-rotary, and air-rotary with pneumatic hammer (EPA 1985).

In conventional-hydraulic (direct circulation) drilling, a drilling fluid is circulated down a rotating drill pipe through the drill bit. The fluid removes the cuttings by returning up the annulus to a settling pit. The hydrostatic pressure of the drilling fluid gives the hole stability.

In air-rotary drilling, high velocity air is used as the drilling fluid. The uphole velocity of air entrains and removes the cuttings from the borehole. This method is best suited for drilling in consolidated rock and allows fast penetration and long bit life as long as water infiltration into the hole is small (EPA 1985).

In air-rotary-with-pneumatic-hammer drilling, either air or drilling mud is used with tophead drive and casing hammer operation (EPA 1985). The casing hammer allows casing to be inserted when drilling through difficult formations such as unconsolidated surface deposits. When such deposits are penetrated, the operation returns to either air or mud circulation drilling for completion of the hole.

The unit cost for rotary drilling a $20-\mathrm{cm}$ borehole is approximately $\$ 40 / \mathrm{ft}(\$ 1.31 / \mathrm{cm})$ (see Appendix C).

\subsubsection{Sonic Drilling}

Sonic drilling employs aspects of rotary and cable tool drilling. Vertical oscillations are imparted to the drill string by two counter-rotating eccentric weights mounted in a unit on top of the hydraulic pull-down rig. This generates vertical movement of the drill string, which enhances drilling efficiency when combined with drill string rotation. Cuttings are removed by bailing. Sonic drilling was recently tested at the Hanford Site in Washington State and at Sandia National Laboratory in New Mexico. 


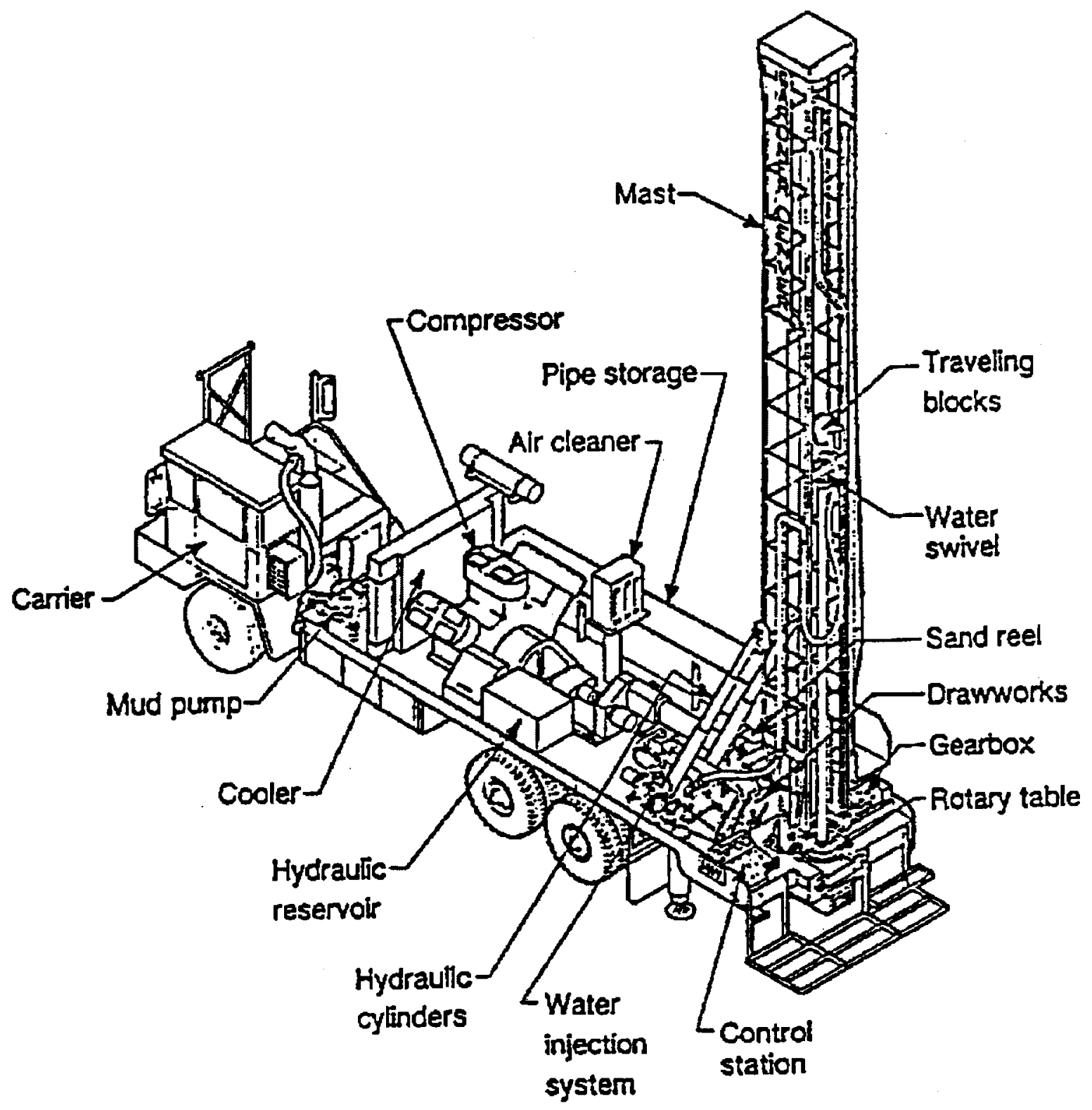

Figure 3.8. Rotary Drilling Machine

\subsubsection{Jetting Methods}

Jetting involves the use of a high-velocity stream of water to sluice out earth materials while a casing is lowered into the deepening hole (Figure 3.9). Fine cuttings are entrained by the water to the top of the hole and are usually discharged to a settling basin. 


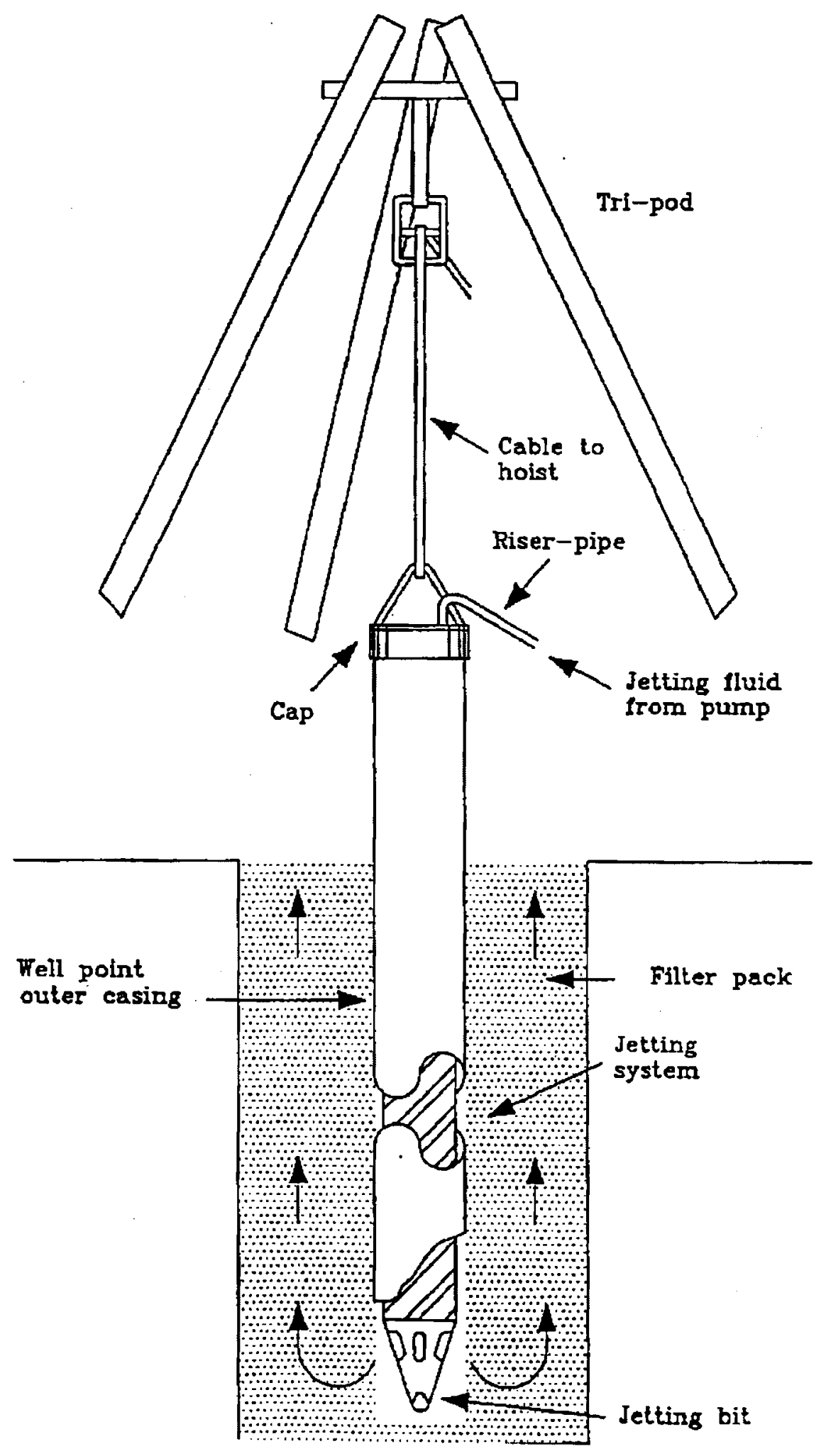

Figure 3.9. Typical Soil Jetting Device 
Several methods exist for jetting shallow wells with diameters of 8 to $10 \mathrm{~cm}$. The self-jetting method employs a permanent drop tube outfitted with jets. In this case, the entire wellpoint is jetted down and remains in place. Riser tubes or casings are used to extend the length of the well as jetting proceeds.

Another jetting method uses a capped pipe fitted with cutting teeth at the bottom end. The pipe is jetted into the soil by water forced through openings in the cap. In difficult drilling situations, the pipe is used as a drill to aid the jetting process. A limitation of this technology is the loss of water circulation in porous formations caused by infiltration into the formation.

The SoilSaw (a trademark of Brown \& Root Environmental, Houston, Texas) jetting technology is a one-step in situ method of constructing soil bentonite or cement-bentonite slurry walls. The system uses Halliburton high-pressure pumps to accelerate a cement-bentonite slurry mixture through multiple jets placed at regular intervals along a high-pressure fluid conduit. The high-velocity slurry impacts the soil, disrupts the soil structure, and creates an intimate blend of soil and slurry. The conduit is raised and lowered, and moved in a horizontal line while pumping to form an in situ slurry wall. This technology is probably suitable for emplacing materials capable of forming a permeable barrier.

\subsubsection{Injection-Mixing in Drilled Holes}

Once the hole is emplaced using augering or drilling, the casing, if present, can be partially retracted. A jet pipe with a conduit for adding barrier-forming solids can then be inserted to the bottom of the hole. Jetting at high pressures while adding barrier-forming solids results in mixing the solids and soil. A columnar barrier is formed as the jet and casing are slowly raised. Overlapping the columns creates a barrier wall. This may require simultaneous jet mixing in adjacent holes if the jet has suñicient potential to cut through the soil to adjacent holes. A similar approach is well developed for forming grout curtains to stabilize soil formations for construction purposes and to create impermeable barriers downgradient of groundwater plumes (EPA 1990). Jetting is not effective in hard rock formations or when large cobbles are present because of its limited radial penetration distance.

If the barrier-forming material is a solution free of solids, it may be injected into permeable formations using gravity. The casing must be removed or slotted to allow passage of the solution into the formation over the full depth of the hole. Less permeable soil formations require pressure injection: the upper section of the casing must be sealed to the formation to allow high pressures to develop in the hole.

\subsection{Horizontal Permeable Barrier Emplacement Technologies}

Horizontal barriers are designed for emplacement in the unsaturated zone under waste disposal sites. Certain horizontal barrier technologies may also be amenable to applications in the saturated zone. Permeable barriers installed in the saturated zone may be effective in limiting vertical migration of contaminants in the groundwater. 
Horizontal barrier technologies that create horizontal holes by horizontal boring, drilling, microtunneling, or compaction boring must be augmented with barrier-material emplacement methods such as those described in Section 3.1.3.7. A typical machine that produces horizontal holes, e.g., horizontal boring machine, is depicted in Figure 3.10. The use of drilling, microtunneling, or compaction boring also requires that holes be overlapped to create a continuous barrier. Holes separated by less than one hole diameter must be filled with barrier materials before intersecting holes are drilled. Filling separated holes provides structural support to the formation and thereby prevents subsidence.

Barrier-forming materials added to the horizontal holes in a slurry form will run out if not contained. This may require special emplacement methods, such as pneumatic transfer devices, pumping of highly viscous slurries, or augering, to emplace solid materials in the holes. Solid barrier materials may also require mechanical compaction during installation. This compaction is done with horizontal rams to adequately support the soil formation above and to ensure a high-quality barrier with respect to vertical load.

\subsubsection{Horizontal Drilling}

Horizontal drilling, like vertical drilling, requires drilling fluids such as drilling mud or air to aid in removing cuttings. Holes can be drilled using a variety of different machines similar to those described in Section 3.1. Casing can be installed after the well has been completed in some techniques. If a hollow-stem auger is used, the casing can be installed through the hollow stem and held in place while the auger is withdrawn. Experimental horizontal drilling using short-radius directional drilling tools and a mud-rotary drilling system is currently being tested (K\&M/BDM 1992). This technology requires the casing to be drawn along by the drilling system as the borehole is advanced. Encased horizontal holes have been completed up to distances of approximately $152 \mathrm{~m}$.

The difficulty of drilling cobbles and boulders in unconsolidated sediments where the boulders cause the drill bit to deviate off course is a major limitation of horizontal drilling technology. Large cobbles and boulders cannot be flushed from the hole; retrieval methods for their removal may require development.

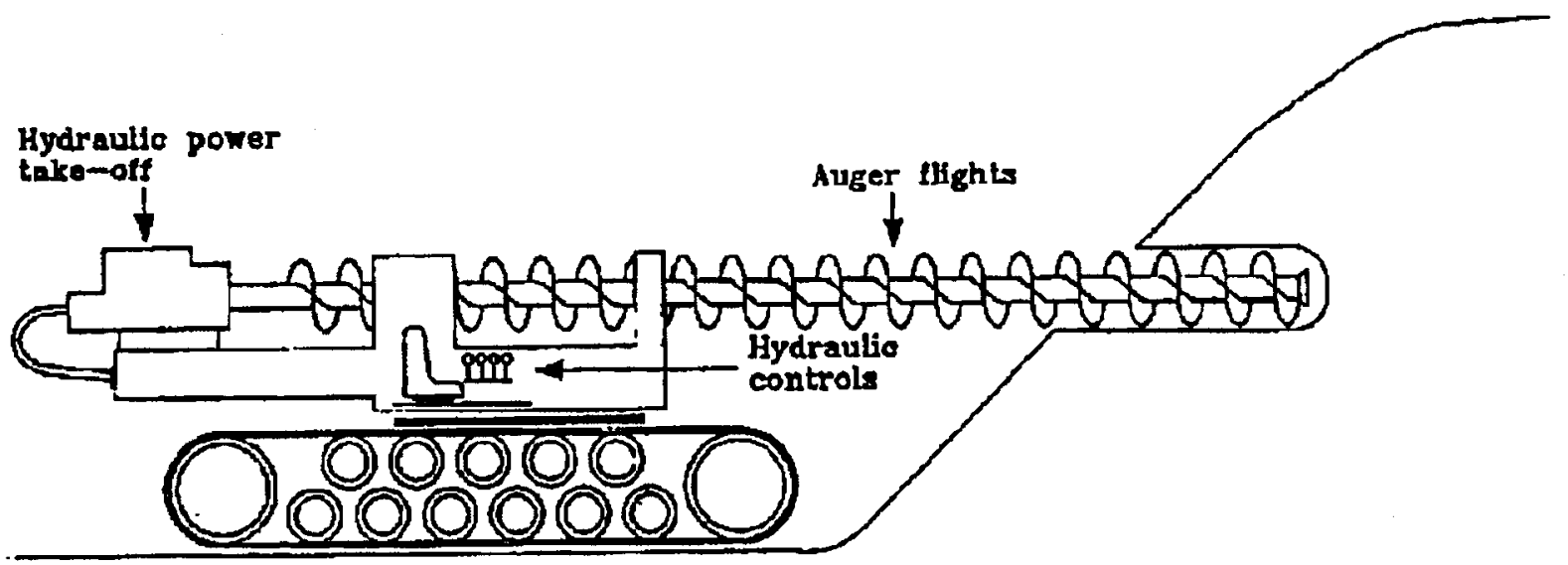

Figure 3.10. Typical Horizontal Boring Machine 
Horizontal drilling may be accomplished through the face of an excavation or through the face of a large borehole. Drilling from a borehole location would require installing a metal or concrete caisson to stabilize the hole, and then drilling radial horizontal holes at the same level or different levels. The technology is developed and has been used for groundwater extraction (Acker 1974), and could be used in both saturated and unsaturated media.

\subsubsection{Microtunneling}

Microtunnels as long as $305 \mathrm{~m}$ can be drilled using a remotely guided tunneling machine (Figure 3.11). A slurry spoils removal system is required. The tunneling machine enters through the side of a 6-m-diameter caisson and requires an exit caisson because these machines cannot back up a sufficient distance to exit. A 6-m-diameter boring machine is needed to make the hole for the caissons entry and exit. A typical $61-\mathrm{cm}$ microtunneling machine would have the capability to tunnel a set of parallel tunnels from deep caissons. The ability of the machine to turn long-radius corners minimizes the number of caissons required. Small cobbles and boulders up to $30 \%$ of the diameter of the microtunnel can be drilled. However, the machine cannot back up sufficiently to move around obstacles. The laser-sighting device for remotely guiding the machine allows positioning of tunnels to within 6 in. of a designed position (K\&M/BDM 1992).

Microtunneling may be used at the surface to create horizontal holes if the horizontal barrier's depth is not excessive and if sufficient real estate and lack of obstructions exist beyond the boundaries of the waste site. In this scenario, the microtunneling machine would begin drilling at the surface and gradually arc to a horizontal orientation under the waste site.

\subsubsection{Compaction Boring}

Compaction boring creates a hole using high force to push a boring rod into the ground. No spoils are generated because the displaced soil particles are compacted into the available pore space. The

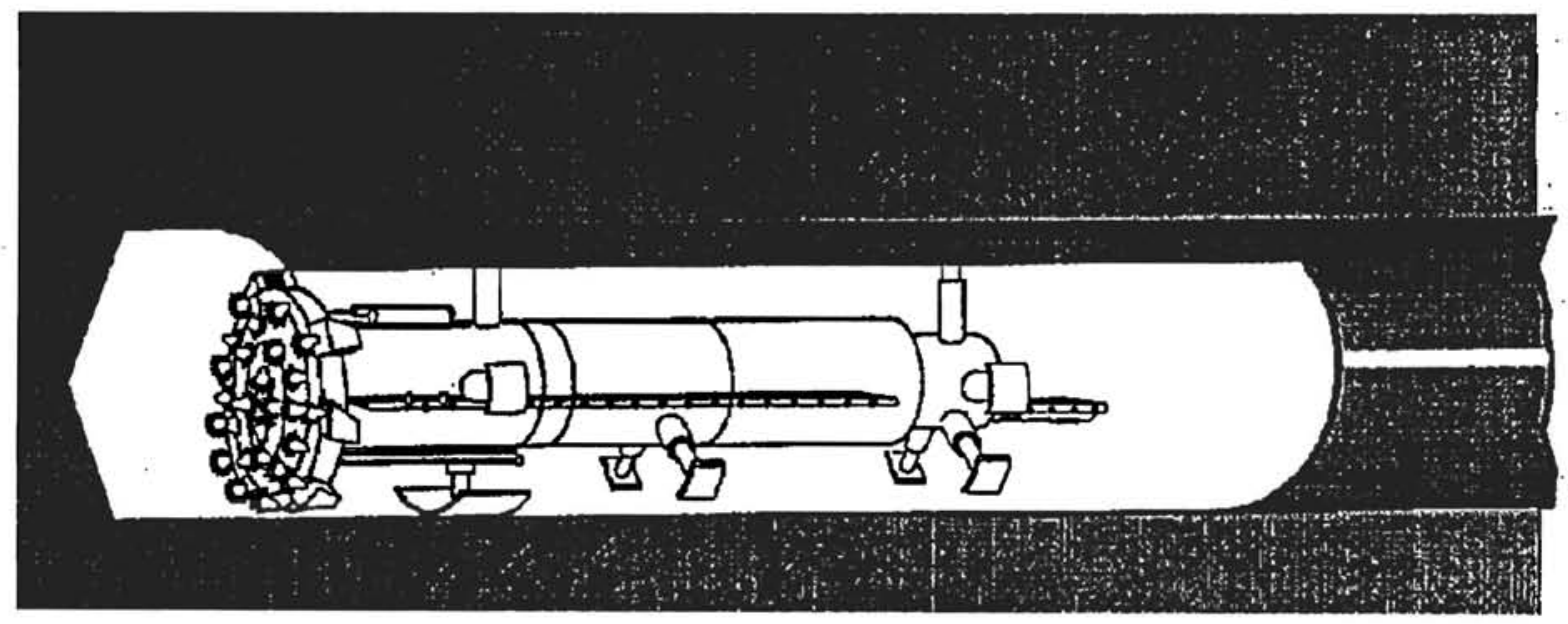

Figure 3.11. Typical Microtunneling Machine 
hydraulic rams used to thrust the boring device through the soils have a very limited depth capability because of the increasing pressure requirements and the devices' strength limitations. Currently, planned modifications may allow penetration to depths of approximately $23 \mathrm{~m}$ (K\&M/BDM 1992). This technology, which has been developed for creating vertical holes, could be adapted for drilling horizontal boreholes from caissons or trenches.

The compaction boring method is not well suited for drilling in soils containing large cobbles, but boring devices can usually displace small cobbles or maneuver around them with some deflection of the hole. This technology is spoilless and, therefore, does not require any disposal of borehole cuttings.

\subsubsection{Horizontal Barrier Emplacement}

\subsubsection{Horizontal Barrier Emplacement by Directional Drilling}

Horizontal barrier emplacement by directional drilling, being developed by Brown \& Root Environmental, uses spoilless horizontal drilling technology to create small-diameter boreholes. This is similar to compaction boring (see Section 3.2.1.2), except that the drill pipe remains in the uncased hole as a guide for the subsurface tool bar that emplaces the barrier material. The barrier material is injected in holes placed in parallel "parabola-shaped" paths 3- to 6-m apart under the contaminated soil. This injection process is repeated side-by-side in adjacent parallel holes until a continuous sheet is formed under the waste.

The main advantages of this horizontal barrier emplacement system are 1) no restrictions on the size of the waste area, 2) a continuous homogeneous barrier is formed, 3) waste above the barrier is not disturbed, and 4) verification instrumentation can be placed during barrier formation.

The main disadvantage is this system has not been demonstrated as a barrier replacement method.

\subsubsection{Longwall Mining}

Longwall mining employs established ore mining technology. This technology offers a possibility for direct emplacement of a permeable barrier into the subsurface as excavation progresses. The excavated soil can be mixed with the barrier materials and continuously returned to the mined-out space. The height of the mined excavation can be readily controlled to ensure emplacement of the required thickness of the barrier. A typical longwall mining machine is shown schematically in Figure 3.12.

Mining heights can be adjusted to as little as $0.6 \mathrm{~m}$. Because the mining system uses a mechanized-roof shielding system for support in unconsolidated soils, the mining can be done remotely with a limited number of miners present.

A potential disadvantage of this technology is that the soil's formations may flow or run. This could impede the mining operation or bury the machine in a condition that makes retrieval difficult. The potential for roof collapse may require stabilizing the soil by injection grouting before application of this technology. Some subsidence may also occur because of the difficulty of achieving the required level of compaction to support the roof. This is a key hazard to be considered in the application of this technology. 


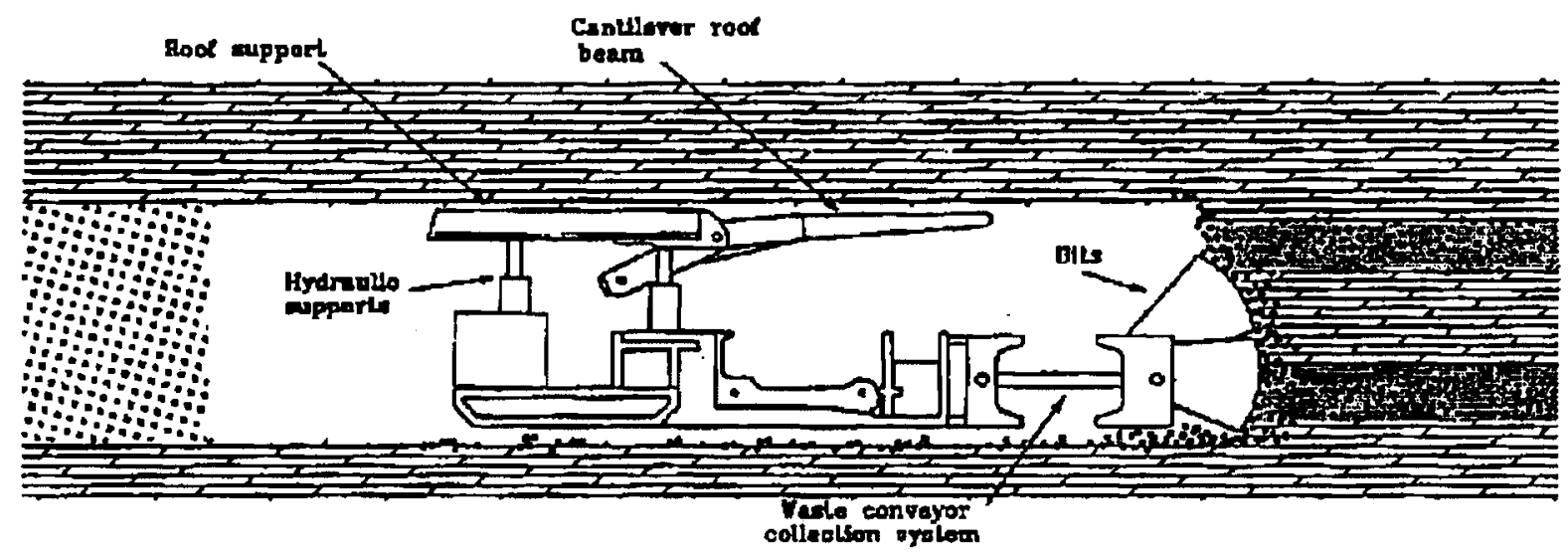

Figure 3.12. Longwall Mining Machine

\subsubsection{Hydraulic Fracturing}

Hydraulic fracturing is widely used in the petroleum industry to stimulate the release and recovery of oil and gas from geologic formations. It has also been used at Oak Ridge National Laboratory as a means of disposing radioactive waste grout between layers of bedded shale (Weeren 1972). This technology injects water or slurry at pressures exceeding the lithostatic pressure of a formation at the bottom of a borehole. The fluid pressure generates fractures that propagate from the borehole. Sand or other propping agents can be introduced into the fracture to hold it open and create a permeable pathway.

This technology holds potential for injection of permeable barrier materials in various geologic media such as consolidated bedrock and glacial tills with fracturing and bedding planes.

\subsubsection{Jetting Methods}

Two jetting methods may be applicable for emplacing permeable barriers: kerfing and jet slurrying.

Kerfing is a jetting technology currently used to produce a notch or slot either perpendicular or parallel to the axis of a previously drilled borehole (EPA 1990). A potential extension of the kerfing technology is using a high-pressure water jet and an abrasive material to cut a slot along the full length of the borehole. The high-pressure jet is placed in the borehole, where it is moved without rotation along the axis of the hole to create and axial slot. Controlled, partial rotation of the jet may be necessary to cut a slot with a relatively uniform thickness. The jet may advance the slot at a rate of several centimeters per second with a depth of penetration of approximately $3 \mathrm{~m}$. The slot can be filled with permeable barrier material.

Jet slurrying uses a water jet to fragment a formation. The jet is introduced into the borehole and can be rotated 360 degrees. The slurry created will drain through the horizontal borehole, which requires casing to prevent its collapse. The borehole can then be backfilled as the casing is withdrawn. The soil-filled space between two nonintersecting, backfilled holes must be drilled and backfilled to create a planar barrier. 


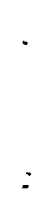




\subsection{Monitoring Methods to Assess Barrier Performance}

The quality of permeable barriers must be controlled and ensured during emplacement to verify that material and installation specifications have been met. Continuous or periodic monitoring over barrier design lifetimes is required to verify that the barrier is functioning as expected. The type and degree of quality control must be tailored to the specific barrier technology, the contaminants present, and the geologic and hydrogeologic conditions at the waste site. For example, during emplacement of a vertical barrier using excavation and backfilling techniques, the quality controls may include verifying that the barrier material's moisture content and particle sizes fall within acceptable ranges. Videotaping of the filling process may be necessary to verify that dirt sloughing from the excavated wall did not occur. Laboratory tests of barrier material samples are required on a regular basis to verify that the barrier is reducing contaminants' migration rates to the required level.

As another example, in the installation of a horizontal barrier in the unsaturated zone by injecting a solution, drilling samples or soil cores at specified intervals may be needed first to assess the variability in hydraulic conductivity. This information can help evaluate and confirm the feasibility of the technology at a specific site. The information may also be necessary for modeling the time and pressure of injection for each hole to ensure that the injected solution plumes overlap. The quality control applied during injection may include recording of injection solution batch makeup data, solution viscosity (which impacts conductivity), and the time and pressure of injection.

Requirements for monitoring the long-term performance of a barrier will be unique to the specific barrier type, the contaminants present, the hydrogeology of the site, the geochemistry of the site, and other factors. For example, monitoring a saturated zone barrier downgradient of a radioactive plume containing high levels of heavy metals may include the use of wells installed through the centerline of the barrier. These wells could be used for sampling and/or realtime radiation monitoring for breakthrough of contaminants. The water table in wells installed upgradient and downgradient of the barrier could also be measured for signs. of increasing gradients, indicating that precipitates are plugging barrier porosity. Upgradient and downgradient wells at different depths could be sampled and analyzed for direct measurement of barrier effectiveness.

Sections 4.1 through 4.3 discuss three categories of quality control and monitoring methods applicable to the installation and performance verification of permeable barriers. These include 1) inference by monitoring the emplacement process, 2) sampling and analysis, and 3) nondestructive monitoring.

\subsection{Emplacement Process Monitoring}

The emplacement of most of the subsurface barrier types in this report cannot be observed directly. Remote viewing devices, including remote television, borescopes, and fiberoptics, may be used on some emplacement technologies. In certain cases, the quality of the emplaced barrier may be inferred by monitoring or measuring emplacement parameters. Some examples of measurable parameters and what they indicate are provided below. 
- Jetting water flow rates and pressures, nozzle rotation rates, and jet pipe advancement rates-are indications the depth of penetration of the jet and diameter of the hole created

- Measurement of volume of barrier material emplaced versus measured volume of soil removed-are an indication of completeness of filling the hole and/or hole collapse

- Rate of pulling casing while emplacing barrier-forming material versus rate of emplacing barrier material-are an indication that the hole has not collapsed before being filled with barrier material.

- Drilling/boring rate torque and/or soil classification logs as a function of advancement distance-indicates geologic conditions that may correlate with the difficulty of jetting a hole or kerfing a slot at a given location. This information may show that longer jetting or kerfing times and/or higher jetting pressures and flow rates are required at locations with more consolidated sediment

- Measurement of the uplift of surface soils-indicates the thickness and extent of barrier materials' emplacement by hydrofracturing

- Pressure, time, and volume of injection of barrier-forming solutions with measurement of solution viscosity, soil hydraulic conductivity, and soil porosity-indicates the penetration radius of the barrier-forming solution

- Pressure applied by barrier-material compaction rams and number of thrusts per unit of barrier material added-indicates the bulk density of the emplaced barrier material.

In many cases, these and other indirect indicators of the quality of the hole/excavation and the emplaced barrier may provide the most practical means of assuring that an acceptable barrier has been emplaced. This approach can be augmented by sampling and analysis during the emplacement process for direct verification of quality.

\subsection{Sampling and Analysis}

Sampling and analysis can be used to control and ensure the quality of the emplaced barrier as well as its effectiveness over time. Quality assurance may necessitate the removal of cores or other representative samples of the emplaced barrier and testing for conformance to emplacement specifications. Borehole sampling can be conducted in either vertical or horizontal orientations. Boreholes may require filling using appropriate materials and techniques to re-establish the integrity of the barrier. Analyses of the samples may include thickness, bulk density, weight percent barrier formers, and uniformity of distribution of barrier formers.

\subsubsection{Borehole Sampling Techniques}

In borehole sampling, representative samples are collected that have 1) undergone a minimal amount of physical disturbance, and 2) not changed chemically as a result of the sampling method. 
Samples obtained by augering, wash boring, and rotary cutting are generally unsuitable because they are nonrepresentative of the emplaced barrier material. Only downhole direct sampling methods provide representative or undisturbed samples. These samples are obtained using devices such as thin-wall tube samples, split spoon samplers, and core-barrel samplers (Table 4.1).

\subsubsection{Thin-Wall Tube Sampling}

Several types of thin-wall tube samplers have been designed for use in different soil types. These samplers generally fall into two broad categories: open-tube samplers and piston samplers.

Open-tube thin-wall samplers are simply tubes that are pushed into the soil until the sampler is filled. The friction between the soil and the interior wall of the tube holds the sample within the tube as the sampler is withdrawn.

Piston samplers have internal pistons that generate a vacuum within the sampler as it is withdrawn from the soil. The vacuum increases the likelihood of withdrawing an intact sample. Large cobbles or gravel, whether in sand or clay, can limit the effectiveness of sample recovery. Two thin-wall sampling devices, the Pitcher sampler and the Denison sampler, employ tubes held in rotating core barrels. This technology requires the use of a drilling fluid, which may limit the ability to collect representative samples in certain barrier types.

\subsubsection{Split-Spoon Sampling}

The split-spoon sampler is applicable to well-consolidated and dense materials as well as to soft materials. Split-spoon samplers are typically lowered to the bottom of a borehole using solid drill rods. A drive weight is used to hammer the sampler into the soil. The hammering action of the sampler results in some physical disturbance of the sample.

\subsubsection{Core-Barrel Sampling}

Core-barrel sampling is generally used for sampling rock formations, but may be applicable to barrier materials that are cemented. Core-barrel sampling uses a rotary drilling rig. The core-barrel sampling device typically consists of a hollow sample barrel, a diamond-tooth coring bit, and a drilling fluid. The coring bit cuts a cylindrical core of rock, which is held inside the core-barrel for subsequent retrieval. The introduction of drilling fluids may limit the usefulness of this sampling technology.

\subsubsection{Groundwater Sampling Techniques}

Monitoring the effectiveness of barrier performance is best accomplished by obtaining groundwater samples. Groundwater sampling from wells below the water table is a well-developed and understood technology. Advantages and disadvantages of several well water-sampling devices are summarized in Table 4.2. Certain sampling devices such as bailers, suction-lift pumps, and air-lift pumps may change the water chemistry and should be employed only when their effects will not impact the evaluation of barrier effectiveness. 
Table 4.1. Types of Borehole Samplers

\begin{tabular}{|c|c|c|}
\hline Method & Applicability & Limitations \\
\hline $\begin{array}{l}\text { Fixed-piston } \\
\text { sampler }\end{array}$ & $\begin{array}{l}\text { Undisturbed samples in cohesive soils, silt, and sands } \\
\text { above or below water table. }\end{array}$ & Ineffective in cohesionless soils. \\
\hline $\begin{array}{l}\text { Hydraulic piston } \\
\text { sampler } \\
\text { (Osterberg) }\end{array}$ & $\begin{array}{l}\text { Undisturbed samples in cohesive soils, silts, and sands } \\
\text { above or below water table. }\end{array}$ & $\begin{array}{l}\text { Not possible to limit the length of } \\
\text { push or to determine amount of partial } \\
\text { sampler penetration during push. }\end{array}$ \\
\hline $\begin{array}{l}\text { Stationary piston } \\
\text { sampler }\end{array}$ & $\begin{array}{l}\text { Undisturbed samples in stiff cohesive soils; representative } \\
\text { samples in soft to medium cohesive soils, silts, and some } \\
\text { sands. }\end{array}$ & -- \\
\hline $\begin{array}{l}\text { Free piston } \\
\text { sampler }\end{array}$ & $\begin{array}{l}\text { Undisturbed samples in stiff cohesive soils. Representative } \\
\text { samples in soft to medium cohesive soils and silts. }\end{array}$ & Not suitable for cohesionless soils. \\
\hline $\begin{array}{l}\text { Open-drive } \\
\text { sampler }\end{array}$ & $\begin{array}{l}\text { Undisturbed samples in stiff cohesive soils. Representative } \\
\text { samples in soft to medium cohesive soils and silts. }\end{array}$ & Not suitable for cohesionless soils. \\
\hline Pitcher sampler & $\begin{array}{l}\text { Undisturbed samples in hard, brittle, cohesive soils and } \\
\text { cemented sands. Representative samples in soft to medium } \\
\text { cohesive soils and silts. Representative samples may also } \\
\text { be obtained in cohesionless soils but with variable success. }\end{array}$ & $\begin{array}{l}\text { Frequently ineffective in cohesionless } \\
\text { soils. }\end{array}$ \\
\hline Denison sampler & $\begin{array}{l}\text { Undisturbed samples in stiff to hard cohesive soils, } \\
\text { cemented sands and soft rocks. Representative samples } \\
\text { may be obtained in cohesionless materials with variable } \\
\text { success. }\end{array}$ & $\begin{array}{l}\text { Not suitable for undisturbed sampling } \\
\text { in loose cohesionless soils or soft } \\
\text { cohesive soils. }\end{array}$ \\
\hline $\begin{array}{l}\text { Split-spoon } \\
\text { sampler }\end{array}$ & Undisturbed samples in soft to well-consolidated soils. & $\begin{array}{l}\text { Hammering may cause some } \\
\text { disturbance of samples. }\end{array}$ \\
\hline $\begin{array}{l}\text { Core-barrel } \\
\text { sampler }\end{array}$ & $\begin{array}{l}\text { Undisturbed samples of consolidated materials including } \\
\text { cemented soil and bedrock. }\end{array}$ & Requires use of drilling fluids. \\
\hline
\end{tabular}


Table 4.2. Water Sampling Devices for Monitoring Wells

\begin{tabular}{|c|c|c|}
\hline Type & Advantages & Disadvantages \\
\hline Bailer & $\begin{array}{l}\text { Can be constructed in a wide variety of diameters } \\
\text { Can be constructed from a wide variety of materials } \\
\text { No external power source } \\
\text { Extremely portable } \\
\text { Low surface-area-to-volume ratio, resulting in a } \\
\text { very small amount of outgassing of volatile organic } \\
\text { compounds while sample is contained in bailer } \\
\text { Easy to clean } \\
\text { Readily available } \\
\text { Inexpensive }\end{array}$ & $\begin{array}{l}\text { Sampling procedure is time consuming and } \\
\text { sometimes impractical to properly evacuate casing } \\
\text { before taking samples. } \\
\text { Aeration may result when transferring water to the } \\
\text { sample bottle. }\end{array}$ \\
\hline Suction-lift pump & $\begin{array}{l}\text { Relatively portable } \\
\text { Readily available } \\
\text { Inexpensive }\end{array}$ & $\begin{array}{l}\text { Sampling is limited to situations where water levels } \\
\text { are within about } 6 \mathrm{~m} \text { of the ground surface. } \\
\text { Vacuum effect can cause the water to lose some } \\
\text { dissolved gas. }\end{array}$ \\
\hline Air-lift samplers & $\begin{array}{l}\text { Relatively portable } \\
\text { Readily available } \\
\text { Inexpensive } \\
\text { Suitable for well development }\end{array}$ & $\begin{array}{l}\text { Causes changes in carbon dioxide concentrations; } \\
\text { therefore, this method is unsuitable for sampling for } \\
\text { pH-sensitive parameters. } \\
\text { In general, this method is not appropriate for } \\
\text { acquisition of water samples for detailed chemical } \\
\text { analyses because of degassing effect on sample. } \\
\text { Oxygenation is impossible to avoid unless elaborate } \\
\text { precautions are taken. }\end{array}$ \\
\hline $\begin{array}{l}\text { Gas-operated } \\
\text { pump }\end{array}$ & $\begin{array}{l}\text { Can be constructed in diameters as small as } 2.54 \\
\text { cm } \\
\text { Can be constructed from a wide variety of materials } \\
\text { Relatively portable } \\
\text { Reasonable range of pumping rates } \\
\text { Driving gas does not contact water sample, } \\
\text { eliminating possible decontamination or gas } \\
\text { stripping }\end{array}$ & $\begin{array}{l}\text { Gas source required. } \\
\text { Large gas volumes and long cycles are necessary } \\
\text { when pumping from deep wells. } \\
\text { Pumping rates are lower than those of suction or jet } \\
\text { pumps. } \\
\text { Commercial units are relatively expensive. }\end{array}$ \\
\hline $\begin{array}{l}\text { Submersible } \\
\text { pump }\end{array}$ & $\begin{array}{l}\text { Wide range of diameters } \\
\text { Constructed from various materials } \\
\text { 12-volt pump is highly portable; other units are } \\
\text { fairly portable } \\
\text { Depending on size of pump and pumping depths, } \\
\text { relatively large pumping rates are possible for wells } \\
\text { larger than 5.1-cm diameter } \\
\text { Readily available } \\
\text { 4.4-cm helical screw pump has rotor and stator } \\
\text { construction that permits pumping fine-grained } \\
\text { materials without damage to the pump }\end{array}$ & $\begin{array}{l}\text { With one exception, submersible pumps are too } \\
\text { large for 5-cm-diameter pumps. } \\
\text { Conventional units are unable to pump sediment- } \\
\text { laden water without incurring damage to the pump. } \\
\text { 4.4-cm pump delivers low pumping rates at high } \\
\text { heads. } \\
\text { Smallest diameter pump is relatively expensive. }\end{array}$ \\
\hline
\end{tabular}


Monitoring the performance of an unsaturated barrier is more difficult because water flow in the unsaturated zone usually occurs slowly and under unsaturated conditions. The high matric potential of most unsaturated zone soils and slow water migration rates make sample collection a slow process. More timely sampling can be conducted using suction to increase the flow of water from unsaturated soils to a collection device. At least two types of unsaturated zone water sampling devices have been developed: suction lysimeters and pan lysimeters.

Suction lysimeters employ a buried porous vessel constructed of sintered ceramic, metal, or plastic. A level of suction high enough to overcome the matric potential of the soil is applied to the vessel. This causes water to flow into the collection vessel. Tubes leading from the vessel to the surface collect water as it is extracted from the soil. Suction lysimeters can be installed beneath a waste site using slant-hole drilling or horizontal drilling from a caisson or trench.

Pan lysimeters, also known as area tension lysimeters, are flat plates or pans inserted into the soil at a slight angle from horizontal. Pans constructed of sheet piling can be driven into the ground using horizontal hammering or hydraulic ram devices. A caisson or trench large enough to accommodate the length of the pan and the driving device is required. Large cobbles and boulders may interfere with the insertion of the pan. Water collects in the pan and drains to the low point where it can be collected directly or drawn to the surface by a vacuum.

\subsection{Nondestructive Monitoring}

Various subsurface diagnostic tools could indicate the quality and/or the effectiveness of emplaced barriers without sampling. These techniques require installation of equipment in boreholes in contact or in near contact with the barrier material, soil, and/or groundwater. Geophysical techniques that may be adaptable include direct current resistivity, electromagnetic conductivity, spectral gamma-ray logging, ground-penetrating radar, and in situ subsurface parameters monitoring.

\subsubsection{Direct Current Resistivity}

Electrical direct current resistivity has been used effectively for near-surface geophysical studies for over 50 years. The technique introduces currents into the ground through two electrodes and measures the potential differences between two points in the ground with two or more electrodes. A barrier material with a substantially higher or lower resistivity than surrounding soil may enable the highest resolution of incongruities in the barrier. Electrical resistance tomography, an adaptation of this technology, may be able to map the quality of a barrier based on variability in its resistivity (Ramirez et al. 1991).

\subsubsection{Electromagnetic Conductivity}

Electromagnetic conductivity, which provides results similar to those of direct current resistivity, has a direct application and proven history for detecting conductive leachate plumes. The approach defines areal anomalies in electrical conductivity that may be related to barrier quality and/or 
performance. This method has distinct advantages over direct current resistivity techniques. In electromagnetic conductivity, the equipment need not make contact with the ground, the equipment is very portable, and measurements are quickly made.

\subsubsection{Spectral Gamma-Ray Logging}

Spectral gamma-ray logging can perform in situ assays of gamma-ray-emitting nuclides in subsurface units. This type of geophysical logging is regularly performed on the Hanford Site (DOE-RL 1988). Radionuclide concentrations can be determined in boreholes that are dry and either uncased or cased with a single thickness of steel casing. Logs from boreholes that are water-filled, cased with multiple thicknesses of steel casing, and/or cased with a material other than steel can be used for radionuclide identification, but the concentration of the radionuclides cannot be calculated (DOE-RL 1988).

\subsubsection{Ground-Penetrating Radar}

Ground-penetrating radar uses an electromagnetic impulse system that includes a transmitter that generates short pulses in the frequency range of 10 to $1,000 \mathrm{MHz}$. This pulse is radiated into the ground and reflected from interfaces of different dielectric material properties. The reflected pulse is detected with an antenna on the surface. The system is similar to reflection seismology, except electromagnetic energy is used rather than acoustic energy. Ground-penetrating radar may apply to quality monitoring by locating barrier irregularities.

\subsubsection{In Situ Subsurface Parameter Monitoring}

Numerous properties of soil and groundwater can be measured using in situ monitoring devices. These properties include temperature, $\mathrm{pH}, \mathrm{Eh}$, total dissolved solids, specific conductance, dissolved oxygen, and alkalinity. Ion-specific electrodes have also been developed for measuring concentrations of certain chemical ions and can be used in in situ applications. In addition, chemical sensors are being developed that can measure concentrations of certain contaminants in situ.

These measurements may provide data that indicate how well the barrier is performing. 



\subsection{References}

Acker, W. L. 1974. Basic Procedures for Soil Sampling and Core Drilling, Acker Drill Company, Inc., Scranton, Pennsylvania.

ASTM. 1992. Slurry Walls: Design, Construction, and Quality Control, ASTM STP 1129, D. B. Paul, R. R. Davidson, and N. J. Cavalli (editors), American. Society for Testing and Materials, Philadelphia, Pennsylvania.

Baas-Becking, L.G.N, I. R. Kaplan, and D. Moore. 1960. "Limits of the Natural Environment in Terms of pH and Oxidation-Reduction Potentials," J. Geol. Vol. 68, pp. 243-284.

Buol, S. W., F. D. Hole, and R. J. McCracken. 1989. Soil Genesis and Classification, 3rd edition, Iowa State University Press, Ames, Iowa.

Campbell, M. D., G. W. Gee, M. J. Kanyid, and M. L. Rockhold. 1990. Field Lysimeter Test Facility: Second Year (FY 1989) Test Results, PNL-7209, Pacific Northwest Laboratory, Richland, Washington.

Carpenter, D. J., and K. O. Johnson. 1990. Retardation of Uranium and Associated Elements by Chemical Reduction and Precipitation, Morrison-Knudsen Environmental Services, Boise, Idaho.

Corbitt, R. A. (editor). 1990. Standard Handbook of Environmental Engineering, McGraw-Hill Publishing Company, New York.

'DOE-RL. 1988. Preliminary Assessment/Site Inspection Activities on Inactive Waste Sites at Hanford, U.S. Department of Energy, Richland Operations Office, Richland, Washington.

Driscoll, F. G. 1986. Groundwater and Wells, 2nd edition, Johnson Division, St. Paul, Minnesota.

EPA. 1984. Slurry Trench Construction for Pollution Migration Control, EPA/540/2-84/001,

U.S. Environmental Protection Agency, Washington, D.C.

EPA. 1985. Handbook-Remedial Action at Waste Disposal Sites, Revised, EPA/625/6-85/006, U.S. Environmental Protection Agency, Washington, D.C.

EPA. 1990. Handbook on In Situ Treatment of Hazardous Waste-Contaminated Soils, EPA/540/2-90/002, U.S. Environmental Protection Agency, Risk Reduction Engineering Laboratory, Cincinnati, Ohio.

Gillham, R. W., and S. F. O'Hannesin. 1992. "Metal-Catalyzed Abiotic Degradation of Halogenated Organic Compounds," presented at the 1992 IAH Conference, Modern Trends in Hydrogeology, Hamilton, Ontario, Canada, May 10-13. 
Holden, T., J. Newton, P. Sylvestri, M. Diaz, C. Baker, J. G. Herrmann, and D. Guzman. 1989. How to Select Hazardous Waste Treatment Technologies for Soils and Sludges: Alternative, Innovative and Emerging Technologies. Noyes Data Corporation, Park Ridge, New Jersey.

K\&M/BDM. 1992. Evaluation of Alternative Drilling Technologies and Subsurface Confinement Barriers for Single Shell Tanks at Hanford, Phase I, Draft Summary, K\&M Engineering and Consulting and BDM International, Inc., Morgantown, West Virginia.

Koerner, R. M. 1986. Designing with Geosynthetics, 2nd edition, Prentice-Hall Inc., Englewood Cliffs, New Jersey.

Maidment, D. R. (editor). 1993. Handbook of Hydrology, McGraw-Hill, Inc., New York.

Martin, W. J., R. J. Serne, and W. J. Deutsch. 1986. "Laboratory Evaluation of Sodium Sulfide Injection to Facilitate Restoration of In Situ Leached Uranium Ore Zone," Soc. of Mining Eng. AlME Trans., Vol 282, pp. 1840-1847.

Nyer, E. K. 1992. Groundwater Treatment Technology, 2nd edition, Van Nostrand Reinhold, New York.

O'Hannesin, S. F., and R. W. Gillham. 1992. "A Permeable Reaction Wall for In Situ Degradation of Halogenated Organic Compounds," presented at the 45th Canadian Geotechnical Society Conference, Toronto, Ontario, Canada, October 25 to 28.

Ramirez, A., W. Dailey, and D. LeBrecque. 1991. "Electrical Resistance Tomography to Monitor Vadose Zone Water Movement," presented at Environmental Restoration '91 Conference at Pasco, Washington, September 8 to 11 .

Weeren, H. O. 1972. Shale Fracturing Injections at Oak Ridge National Laboratory - 1972 Series, ORNL-TM-4467, Oak Ridge National Laboratory, Oak Ridge, Tennessee.

WHC. 1991. Engineering Evaluation of Containment Alternatives for $N$-Springs Releases, WHC-SD-EN-EE-003, Rev. 0, Westinghouse Hanford Company, Richland, Washington.

WHC. 1993. N Springs Expedited Response Action Proposal, DOE/RL-93-23, Draft A, Westinghouse Hanford Company, Richland, Washington.

Wing, N. R. and G. W. Gee (editors). 1990. Hanford Site Protective Barrier Development Program: Fiscal Year 1989 Highlights, WHC-EP-0318, Westinghouse Hanford Company, Richland, Washington. 
Appendix A

Layne Environmental 



\section{Layne Environmental Servlces, Inc.}

5110A Alver Road East - Tacoma, WA 09443 • 206/926.1192 • Fax: 206/928-0714

March 29, 1993

EBASCO

1201 Jadwin, sulte 202

Richland, WA 99352

Attention: Wade Riggsbee

Reference: Request For Quotation To provide Drilling services At The Hanford Facllity.

Dear Mr. Riggsbee:

Layne is pleased to offer the following quotation for your consideration.

The quote is based on used a CME-850 dr1ll rlg and two man crey. This rig is a track mounted auger rig and would mobllize from Laynes' Woodland, California office.

Mobilization Demobilization

$\$ 6,400.00$

Drilling

30 Dys. $x 10 \mathrm{hrs} / \mathrm{dy}$. $\$ 160.00 / \mathrm{Hr}$. $\$ 48,000.00$

Crew Per Dien

30 Dys. $x 2$ Men

- $\$ 140.00 / \mathrm{Dy}$. $\$ 4,200.00$

steam cleaner

30 Dys.

- $\$ 135.00 / \mathrm{DY}$. $\$ 3,750.00$

TOTAL BSTIMATED COST

This cost estimate is based on drilling twelve to fifteen, fifteen foot soil borings. Borehole abandonments (labor \& materials) have not been included in our pricing. Cuttings contalnment has not been Included.

This estimate is contingent on agreement of final contract terms and conditions, as vell as review of the health and safety plan.

Bincerely,

LAYNE ENVIRONMENTAL SERVICES, INC.

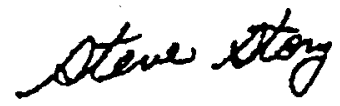

Steve story

Business Development Manager

ss/cb 


\section{RECORD OF TELEPHONE CONVERSATION}

Ebasco Environmental, A Division of

Ebasco Services Incorporated

CALL: DTO $\square$ FROM: Wade Riggsbee TASK:

ORGANIZATION: Layne Environmental DATE: $\underline{03 / 29 / 93}$ TIME: $\underline{1: 10 \text { p.m. }}$

PHONE: Page 1 of 1 SUBJECT: Drilling Costs at the Hanford Site

Contact - Steve Story: He indicated that shallow augering in rad zone would run about $\$ 200 / \mathrm{ft}$ to $\$ 300 / \mathrm{ft}$ with mobilization from Woodland, Cal ifornia. Quote to follow.

He also indicated that costs for augering large diameter boreholes would run about $\$ 42 / \mathrm{ft}$ to $\$ 58 / \mathrm{ft}$ for 18 inches to 48 inches. Average for 8 inches is $\$ 48 / \mathrm{ft}$.

By: Wade Rygles

Distribution: (A copy must be given to the Task Manager) 
Appendix B

Onwego Drilling 



\section{RECORD OF TELEPHONE CONVERSATION}

Ebasco Environmental, A Division of

Ebasco Services Incorporated

CALL: QT TO $\square$ FROM:

ORGANIZATION: Onwago Drilling

PHONE:

SUBJECT: Drilling Costs at the Hanford Site

Contacted Dale Bingham to ask for current drilling costs, including cable tool drilling, outside of the Hanford Site. Mr. Bingham quoted approximately $\$ 53 / \mathrm{ft}$. He referred me to Mr. Don Moak for Hanford drilling costs, however, Mr. Moak is currently semi-retired.

By: Wade Regabee

Distribution: (A copy must be given to the Task Manager)

B. 1 



\section{Appendix C}

Environmental West Exploration, Inc. 

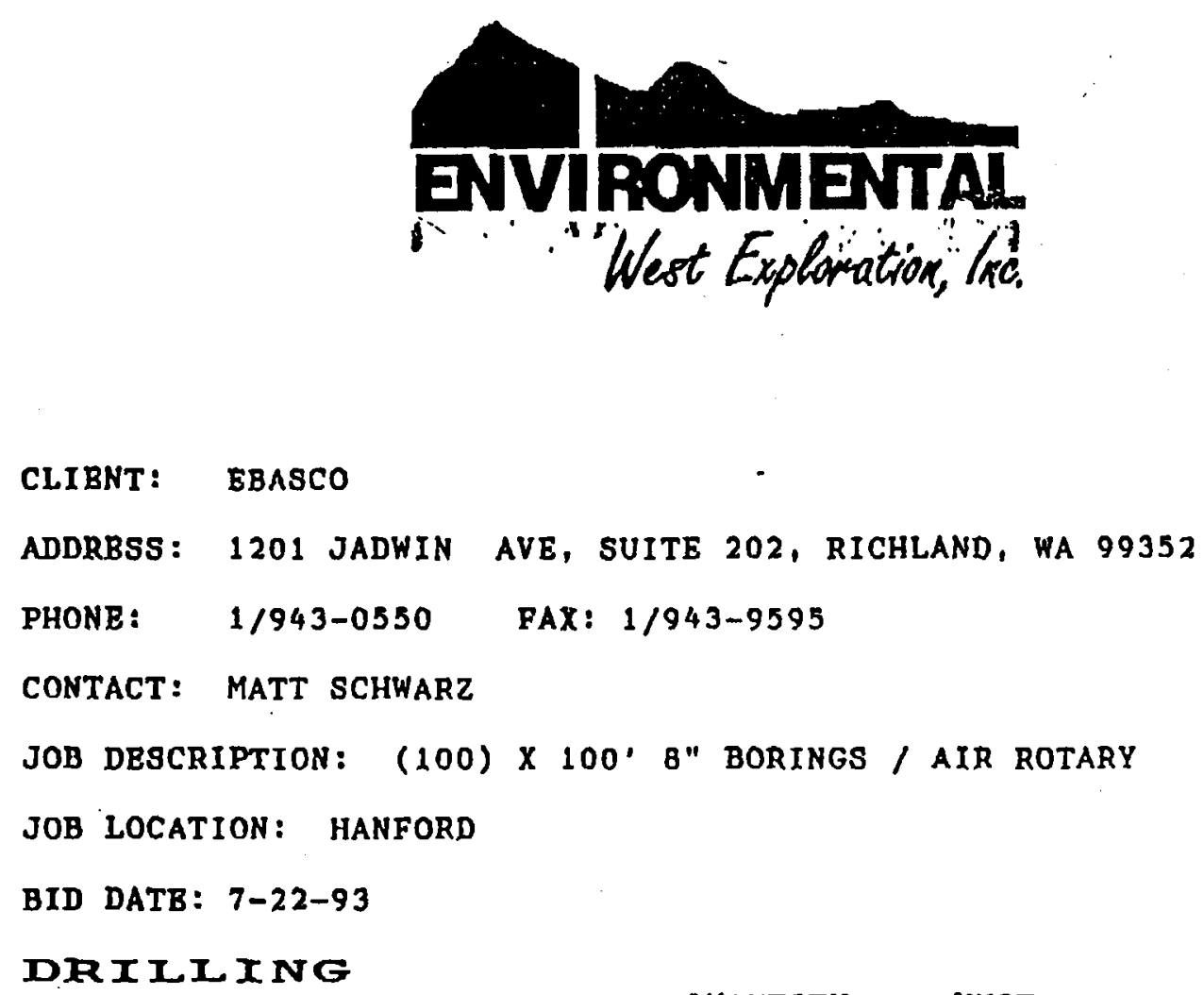

Appendix D

Geo-Con, Inc. 


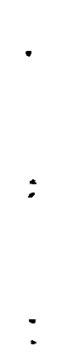




\section{Q GEO CON ${ }^{\circ}$ INC. \\ GEOTECHNICAL CONTRACTING}

RECEIVED

June 22,1993

JUN 251993

Matt Schwarz

Ebasco Environmental

EBASLLU - KIUMLAND

1201 Jadwin Avenue

suite 202

Richland, WA 99352

Dear Mr. Schwarz:

Enclosed please find the technical briefs and case studies you requested.

Geo-Con: is a pittsburgh-based environmental and geotechnical construction company that specializes in onsite remediation, insitu deep and shallow soil mixing, vertical barriers including slurry walls and bio-polymer drainage trenches, and installation of soil and synthetic (HDPE) liners for containment and closures.

If you need additional information about one of our technical capabilities or if you wish to discuss details related to an upcoming project, feel free to contact me in Pittsburgh at (412) 856-7700 or one of our regional offices.

Enclosures

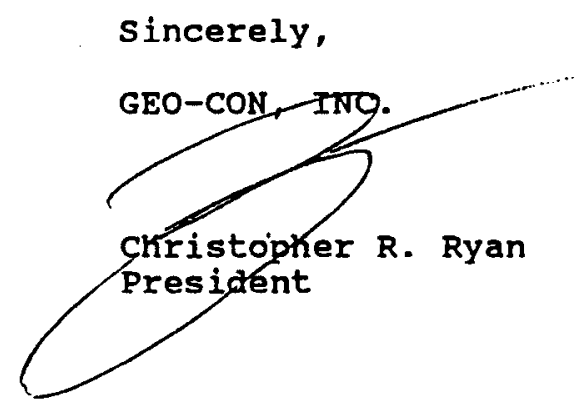

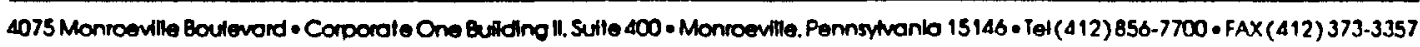

D.1 


\section{CURRENTLY AVAILABLE FROM GEO-CON, INC.:}

\section{- Technical Briefs \\ - Case Studies}

\section{HAZARDOUS WASTE REMEDIATION \\ D Technical Brief - Shallow Soll Mixing \\ 口 Technical Briol - Sludge Stablization \\ 口 Technical Briel - On Site Water Treatment \\ $\square$ Case Sludy No. 1 . Solidilication of Hazardous Waste Sludge \\ Case Siudy No. 2 - Construction of Hazardous Waste Containment Facility \\ Case Study No. 3 - Investigation of Suspected Waste Burial Sile \\ Case Sludy No. 4 - Remediation ol Hazardous Waste Burial Site \\ Case Sludy No. 5 - Remediation of Hazardous Waste Construction Sile \\ $\square$ Case Sludy No. 6 - Fixation of Chemical Waste In-Situ \\ $\square$ Case Sludy No. 7 - Hydraulic Dredging ol Hazardous Waste Sludge}

\section{SLURRY CUT-OFF WALLS}

$\$$ Technical Briel - Soll Bentonite Slurry Walls

口 Technical Brief - Bio-Polymer Slurry Drainage

$\square$ Case Sludy No. 1 - Sanilary Landfill Containment

$\square$ Case Sludy No. 2 - Earthen Dam Cutoff Trench

C Case Sludy No. 3 - Supertund Clean Up

$\square$ Case Sludy No. 4. Dewatering for Liquelaction Reduction

$\$$ Case Sludy No. 5 - Hazardous Waste Containment

\section{DEEP SOIL MIXING (DSM)}

ג Technical Briel - DSM Geotechnical Improvement Processes

Case Siudy No. 1 - DSM Cut-Olf Wall Application

R-Case Siudy No. 2 - DSM Soll Fixation

\section{LANDFILLS/LINERS}

$\square$ Technical Brief - Synthetic Liners

口 Technical Brief - Soll-Bentonite Liners

$\square$ Case Sludy No. 1 - Hazardous Waste Containment

$\square$ Case Sludy No. 2 - Acid Plant Underfloor Liner

- Case Sludy No. 3 - Hazardous Waste Containment

C Case Sludy No. 4 - RCAA Landfill Construction

$\square$ Case Sludy No. 5 - Composite Liner System

$\square$ Case Siudy No. 6 - Soil-Bentonite Liners

\section{DRILLING \& GROUTING}

Technical Brief - Grout Curtains For Cut-Oll and Containment

1 Case Sludy No. 1 - Pin Piles Support Settling Walls

Case Sludy No. 2 - Slabjacking Sulfuric Acid Tanks

区Case Sludy No. 3 - Deep Densification for Site Development

$\square$ Case Sludy No. 4 - Stabilization of Existing Treatment

Lase Sludy No. 5 - Jet Grouting for Vertical Barriers

\section{RETENTION SYSTEMS}

$\square$ Case Sludy No. 1 - Tiebacks Stabilize Failing Wall

$\square$ Ċase Study No. 2 - Tiebacks Support Canal Bulkhead

Case Sludy No. 3 - Soil Nail Wall Underpins Building

\section{DEEP COMPACTION}

D Case Sludy No. 1 - Deep Soil Compaction By Impaction Technique

IF YOU WOULD LIKE A COPY OF ANY OF THE ABOVE, PLEASE INDICATE BY CHECKING THE APPROPRIATE BOXES AND COMPLETE THE FOLLOWING:

NAME MATT SCHWARZ

companY EBASLO ENVIRONMENTAL
TITLE ASSISTANT ENGR TELEPHONESOS 543 OS 50

ADORESS 1201 JADWIN AVE SUITE 202

CITY R/CHLAND COF STATE_WA 99352

$\square$ I have a current application. Please contact me.

FOLD AND STAPE HERE

D.2 


\section{SOIL- BENTONITE SWRRY WALLS}

\section{Technical Brief}

S Geo-Con: Inc Geotechnical Construction P.O. Box 17380 Pittsburgh, PA 15235 (412) $856-7700$

Regional Otfices: CA (415) 887-2002

FL (813) 647.5888 TX (817) $383-1400$ NJ (609) 848-2220

T-SW-01-85

(8) 1900 Geocon. ine.

\section{Soil Bentonite Slurry Walls}

Soil-Bentonite slurry walls are subsurface, nonstructural walls that act as barriers to the lateral flow of groundwater and water-borne pollutants. Soil-Bentonite (SB) cutoff walls are constructed using the siumy trench technique and are composed primarily of soil and bentonite, a natural clay mineral. The principal advantages of SB cutoff walls are the low permeability of the wall and their general suitability for both new and remedial applications.

\section{APPLICATIONS}

The soil-bentonite slurry trench technique has been in use in the United States since the 1940's. The early applications of soil-bentonite walls were for dewatering large excavations and as hydraulic barners in dams and dikes. Recently, there has been a growing number of applications of SB slurny walls for pollution control, particularly on projects where a positive leachate cutoff is required.

Recent advances in the capability of excavating equipment and refinements in technique have brought the cost of slurry walls down. Siurry walls are now. economically competitive on projects where compacted clay cutofts. leachate collectors, sheeting, or well points would have previously been used. Some typical applications are to:

- Seal dams and dikes

- Contain sanitary and hazardous waste landfills

- Dewater structural excavations

- Hydraulically isolate lagoons and holding ponds

- Enclose oil and chemical tank farms

- Interceot seepage from slopes

- Contain oil spills

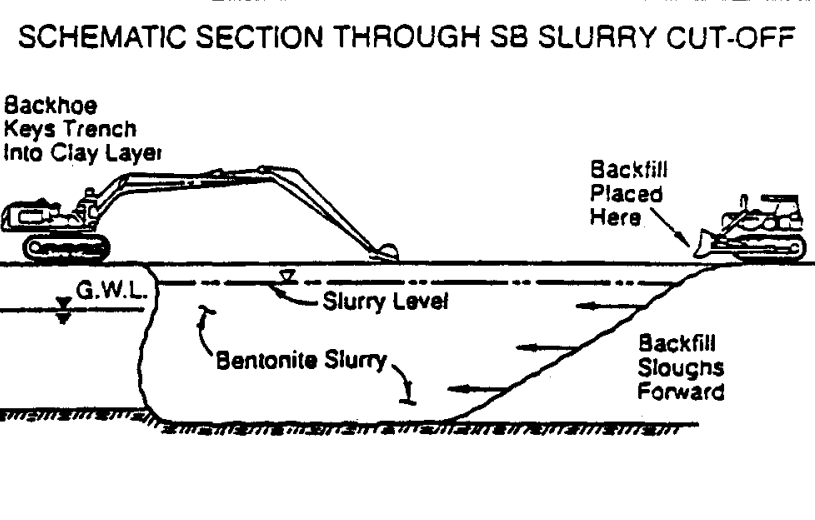

Slurry walls are particularly well suited for remedial appiications. Usually, SB walls can be constructed without disturbing the function or operation of existing facilities.

\section{CONSTRUCTION}

The construction sequence of the cutoff wall is the same whether it is to be used to cutoff groundwater or polluted leachates. The major

characteristic of slurry cutoff wall construction is the use of bentonite-water slurry which allows excavation without the use of other lateral support. Siurry cutoff walls are built by excavating a narrow trench (2-4 ft. wide) while pumping in the slurry and maintaining its level at or near the top of the trench during the excavation process. Usually, the trench is keyed into an underlying

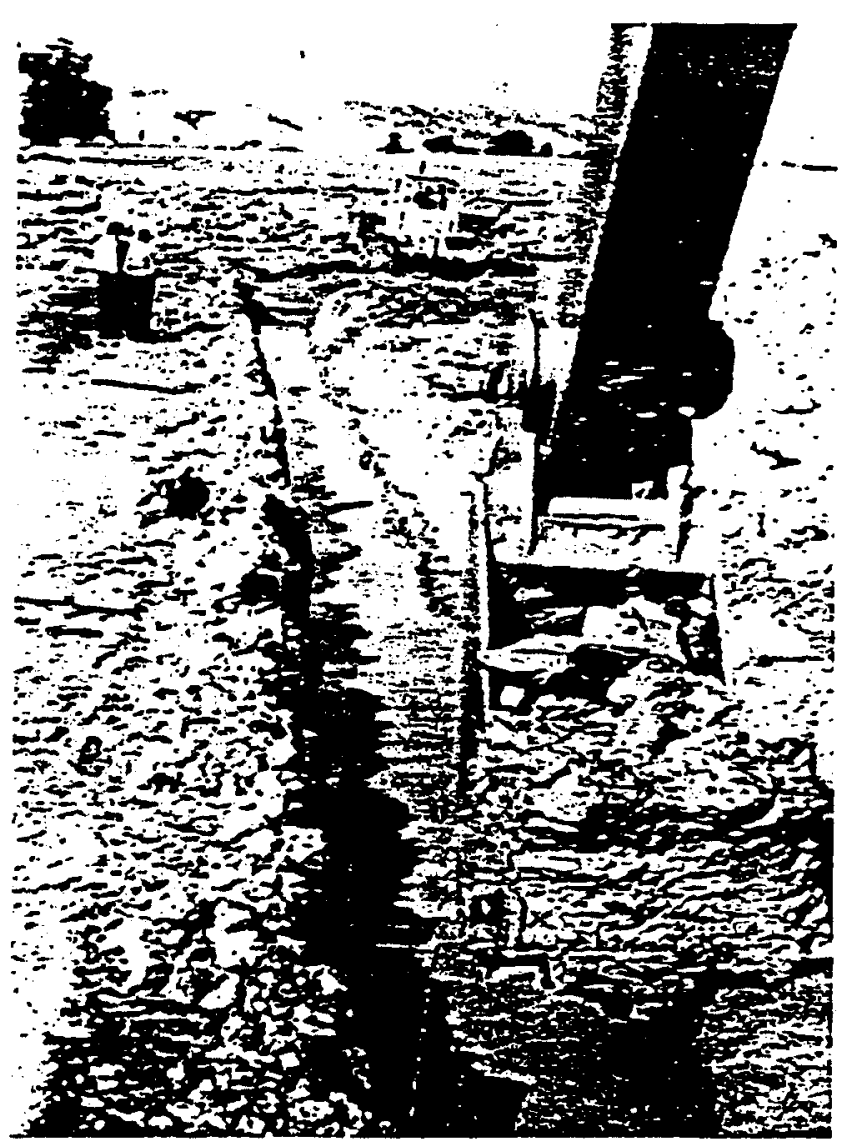


aquiclude. The aquiclude then forms the bottom and the slurry wall the sides of the containment. This narrow trench is then backfilled with impervious materials to form a permanent cutoff. When the backfill consists of a mixture of soil and bentonite, the construction work is called a soilbentonite (SB) siurry cutotf wall.

On projects where the material excavated from the trench is suitable for use as backfill, the SB system can be most economical because of the minimum amount of backfill materials required. After the trench has been excavated under a bentonite slurry. more slurry is mixed with the soil adjacent to the trench. A bulidozer is used to work the material to a consistency similar to wet concrete. It is then pushed back into the trench so that the backfill slope displaces the bentonite slurry forward. Excavation and backfilling are phased to

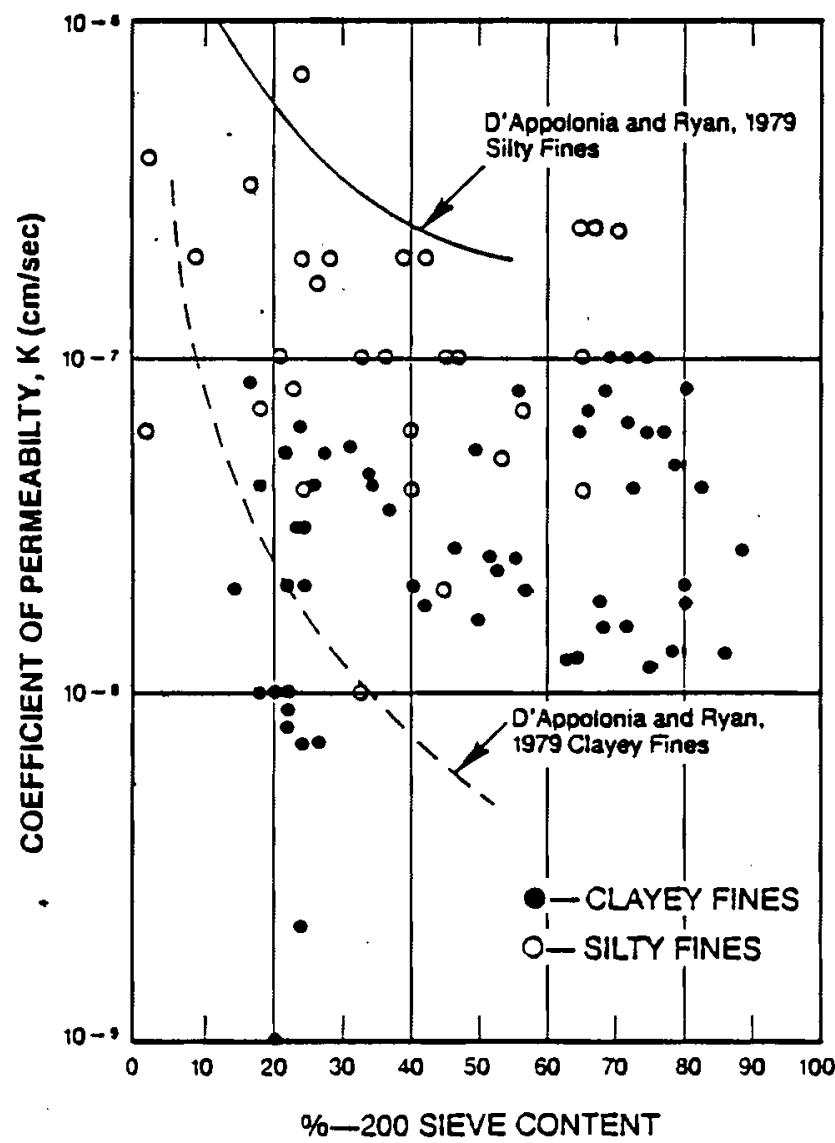
low as $10^{-9} \mathrm{~cm} / \mathrm{sec}$. Improved passing the No. 200 sieve) correlated closely to permeability. Recent Geo-Con data has shown that the factors affecting permeability are more complex than originally thought and that the earlier correlation is unreliable. The overall elfectiveness of the wall depends both on the SB backfill and on the filter cake which is formed as slurry escapes into the surrounding soil. Although the filter cake ( $k<10^{-9} \mathrm{~cm} / \mathrm{sec}$ ) is typically ignored for design purposes. it does contribute to the impermeability of the "in situ" wall.

Permeability is usually the most critical design parameter. S8 cutoff walls normally have a permeability less than $10-0$ $\mathrm{cm} / \mathrm{sec}$ and occasionally as impermeability of an SB wall is usually accomplished by increasing the natural clay content or the bentonite content. Early research on soilbentonite indicated that the percentage of fines (material

The percentage of coarsegrained particles has the greatest effect on both strength and compressibility. As the percentage of coarsegrained particles increases. strength increases and compressibility decreases. While soil-bentonite backfill is semifluid when mixed, within a short time it takes a "set" and usually ends up at a strength and consistency similar to the native soil. In heavily traveled areas which must be used before the wall has had time to gain strength, it is usually advisable to provide crossings over the SB wall. This will prevent damage to the wall and allow for unrestricted traffic. These crossings are usually constructed of compacted clay, steel plates, geofabrics. and/or reinforced concrete. depending upon the application.

Under most conditions, the only strength requirement for SB walls is that they approximately equal the strength of the surrounding soil. Gradually, as the water content of the SB backfill comes to equilibrium with the surrounding soil, this requirement is met. However, another considera. tion which affects both the strength and the stability of the installation concerns the amount of pressure that will build up behind the cutoff wall. In dewatering excavations the wall should be positioned far enough behind the slope to ensure the stability of the excavation.

In any permanent instailation of a slurry cutoff wall, the ability of the wall to remain im. pervious to the underground environment is always an important question. The materials involved are bentonite clay, mixing water, and soil. In situations which involve clean water, these materials are indefinitely stable and no reduction in permeability is experienced. However, if compatibility is in question because of the presence of certain pollutants, iests can be performed using the backfill materiais from the site and the actual groundwater. The bentonite mix can then be ad. justed to provide a satisfacto. ry solution for practically all cases.

Typically, the durability of the S8 wall is unaifected by changes in hydraulic conditions. In order to design the wall to resist piping, the gradation of the SB backfill can be evaluated by filter criteria. Usually, a well-graded backfill is preferred. Since the wall is buried. it is highly unlikely that the wall will dry out and crack. However, to prevent desiccation, the top of the wall may be capped with clay or extra SB backiill.

\section{CONCLUSION}

Siurry cutoif walls are gaining wide recognition for use in dewatering and pollution control. They offer a cosi effective solution to many groundwater problems in new and remedial work. The economy, convenience and sositive control of groundwater afforded by slurry cutoif walls is bringing them acceptance and apolication on an increas. ing number of projec:s. 


\section{SLURRY WALLS}

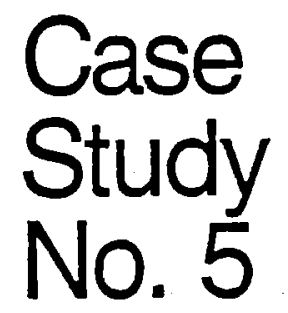

St Geo-Con; Inc. Geotechnical Construction P.O. Box 17380 Pittsburgh, PA 15235 (412) 856-7700

Regional Offices: CA (415) 887-2002 FL (813) 647.5888 TX (817) 383-1400 NJ (609) 848-2220 -

\section{Hazardous Waste Containment}

\section{SOIL-ATTAPULGITE APPLICATION}

An old landfill formerly accepted liquid and barreled wastes and was reclassified as a Class I Landfill and therefore required to close. An existing clay barrier around the landfill was leaking a corrosive leachate into the groundwater. Immediate action was necessary to contain the landfill and prevent further spread of the leachate.

\section{LOCALITY}

San Francisco, California

\section{WHAT HAD TO BE DONE}

Geo-Con working together with the consultant first evaluated the compatibility of various bentonite products with the leachate. It was discovered that the leachate destroyed both conventional and treated bentonites and thus could not be used. Instead, attapulgite clay was used both in the slurry and as a backfill additive to create a contaminant resistant slurry wall with a maximum permeability of $1 \times 10^{7} \mathrm{~cm} / \mathrm{sec}$.

Special slurry mixing equipment was custom-made to blend a stable slurry from the attapulgite. The 40 foot deep

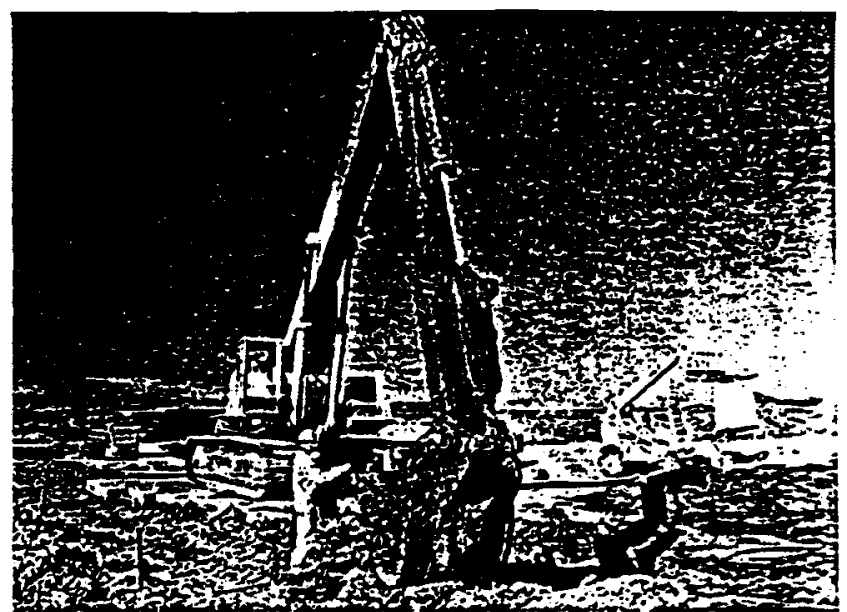

slurry wall had to be five feet wide to match the dimensions of the former barrier, therefore, special retooling of the long stick backhoe was required to accommodate the heavier bucket. The additional width of the trench necessitated additional backfill mixing equipment to process the soil-attapulgite mixture. The proximity of the work to the owner's sanitary landfill and the presence of odors from the contaminates made it imperative to do the trenching at night to minimize exposure of the public to potentially dangerous substances. All workers were properly trained and protected with chemical- resistant suits and breathing apparatus. Post-construction monitoring demonstrated thie successful containment of this toxic leachate.

\section{COMMENTS}

Geo-Con, the consultant, and the owner worked closely together from design througn construction to er:zure a saie. high quality installation. Geo. Con's involvement in the backitil design permitted the economical use of specialty equipment and materiais tor this project.

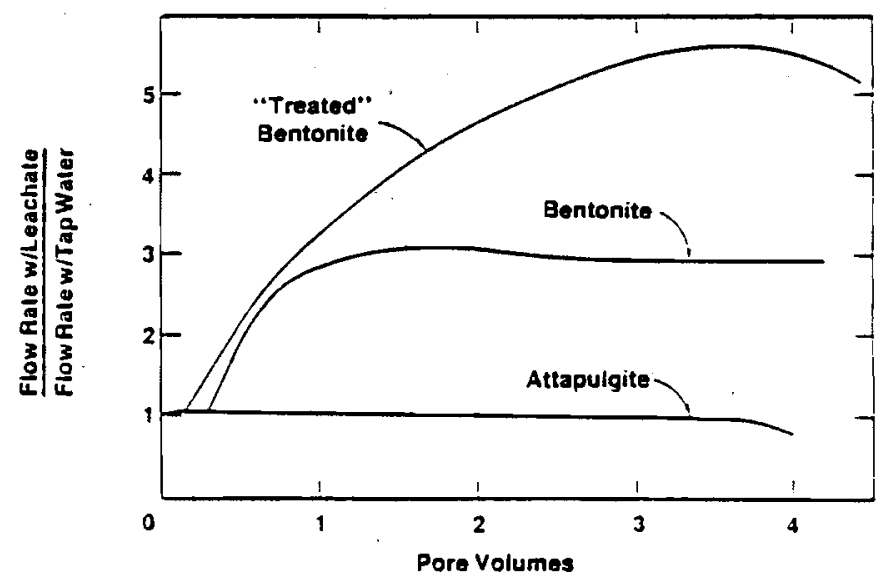

Comparative Flow Rates for Three Clay Products

When Permeated With Leachate and Tap Water

D.5 


\section{DEEP \\ SOIL MIXING}

\section{Technical Brief}

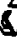
Geotechnical Construction Comorate One-Bldg. II Suite 400

4075 Monroeville Blvd. Monroeville, PA 15146 (412) 856-7700

Regional Offices: CA (510) 887-2002 FL (813) 647.5888 $T X(817) 383-1400$

NJ (609) 848-2220

T-DSM-01-89

Tresescoson une

DSM

Geotechnical Improvement Processes

Deep Soil Mixing is a unique soil improvement technique that can increase strength, reduce permeability and improve other soil properties without excavation. DSM is an economical substitute for many geotechnical improvement processes.

\section{APPLICATIONS}

The DSM system creates overlapping soilcrete columns for:

- Cutoft and retaining walls

- Soil improvement

- Containments

- Foundations

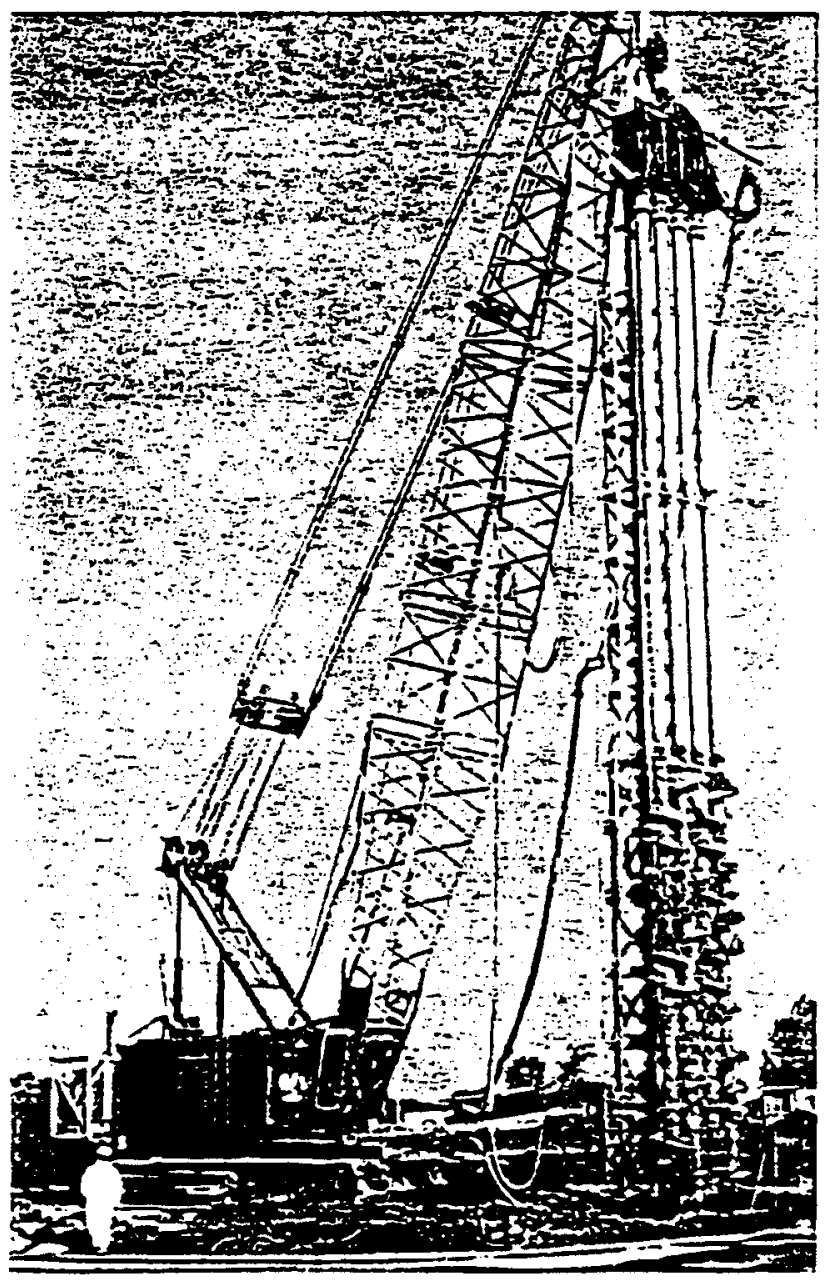

Figura 1

\section{CONSTRUCTION}

The DSM system utilizes a crane supported set of leads which guide a series ( 1 to 4) of thirty-six inch diameter mixing shafts. As the shafts are advanced vertically into the soil, a cement base grout is injected through the hollow stems of the mixing shatts and discharged at the head. By combining auger flights and mixing blades along the shafts, the soil is lifted and blended with the grout in pugmill fashion. Once the design depth is reached, the mixing shaft rotation is reversed and the mixing process is repeated as the shatis are brought to the surtace. leaving a thoroughiy mixed soilcrete column.

Cuntinuity is assured two ways. First, auger flights and mixing blades overlap between adjacent shafts and mechanically create the soilcrete column. Second, the rig penetrates with a multiple set of shafts overlapping the previous column with one shaft and creating new columns with the other shafts. (See Figure 1)

A variety of depths (to 150 feet) and patterns can be utilized to meet individual site requirements. Entire blocks of soil can be mixed by positioning the shafts in overlapping patterns.

(See Figure 2 on back)

\section{DESIGN}

Whether the DSM application is for low permeability, strength or a combination of both, a laboratory testing program is conducted to select an optimum mix design for the soilcrete. A grout flow rate is then matched to a drilling

D. 6 
penetration rate assuring the design amount of grout is mixed per volume of soil.

For structural stability, reinforcing steel or beams can be added to the design and placed in the soilcrete columns while the mix is fluid assuring good bonding of the soilcrete and the steel.

\section{ADVANTAGES}

- no excavation

- quiet, vibration free

- the ability to work in an area with limited amount of space

- treatment and depths up to 150 feet

- effective for a wide variety of soil conditions

- a relatively rapid construction sequence

- easy to adjust mix designs and flows

- not effected by water table, eliminating the need for dewatering

\section{CONCLUSION}

Whether the goal is to improve bearing capacity of sott soils, reduce permeability, provide structural support or improve other soil charac. teristics, DSM system offers a number of advantages over conventional techniques.

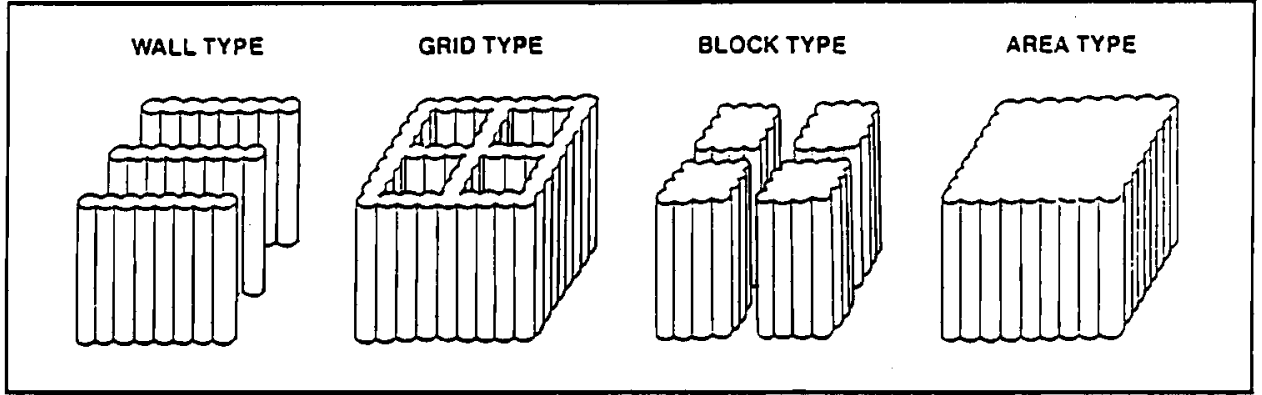

Figure 2

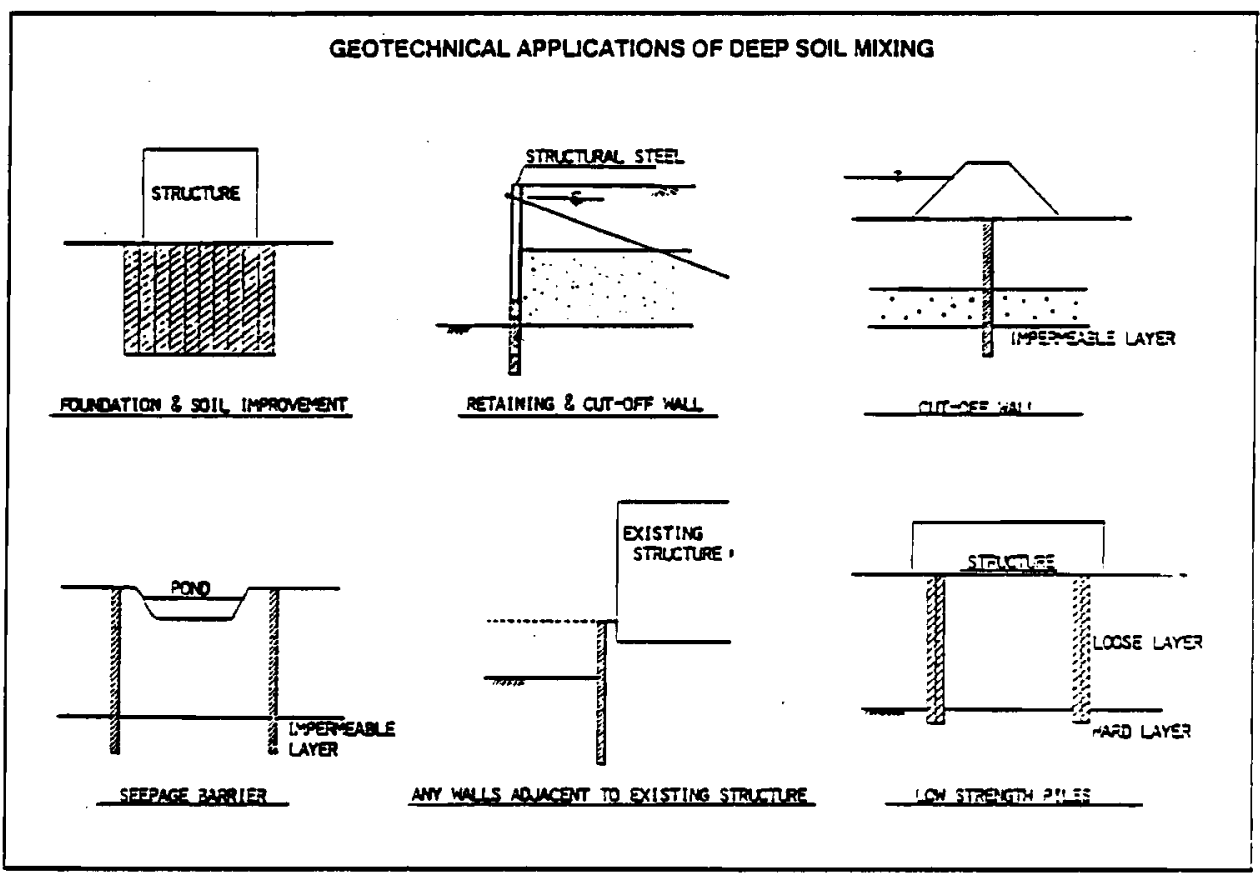

Figure 3 


\section{DEEP SOIL - MIXING}

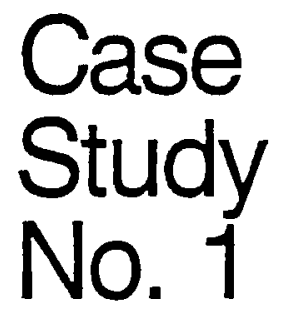

s. Geo-Con, Inc. Geotechnical Construction Corporate One-8Idg. II Suite 400 4075 Monroeville slud. Monroeville, PA 15146 (412) 856-7700

Regional Otfices: CA (510) 887-2002 FL (813) 647-5888 TX (817) 383-1400 NJ (609) 848-2220

C-DSM-01-88 o 1 sess Goocon. Inc.

\section{Deep Soil Mixing}

\section{DSM CUT-OFF WALL APPLICATION}

A large manufacturing firm required an underground vertical barrier (cut-off) wall to isolate two areas of PCB contaminated soils and prevent contaminated groundwater from leaching into a nearby river (see below). The owner chose Geo-Con's Deep Soil Mixing (DSM) method over other conventional methods for the following reasons: (1) placement of the cut-off wall approximately four feet from the river's edge, representing very sott soil conditions along with the hydraulic forces of the river, causing concern that a conventional slurry cut-off wall trench might fail during construction, and (2) since the cut-off wall would be installed in contaminated soil, DSM was an overwheiming choice since it does not require any soil to be excavated during construction.

\section{LOCALITY}

Bay City, Michigan

\section{WHAT HAD TO BE DONE}

Geo-Con's specially designed four auger Deep Soil Mixing rig (above right), was utilized for this project.

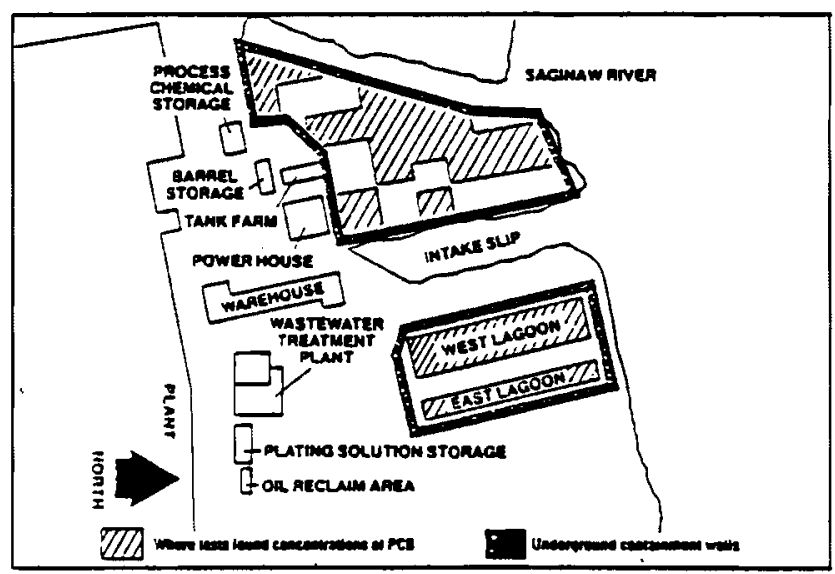

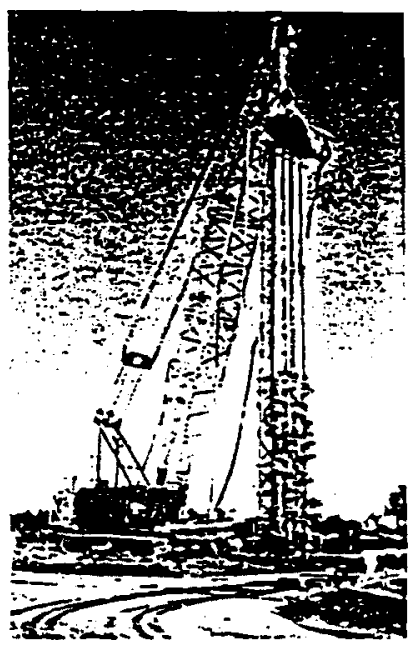

steel beams to allow for future excavation of contaminated soils inside (away from the river) the wall area. Geo-

Con added the steel beams and provided the client with a cantilevered retaining wall capable of holding back the load applied. Comprehensive health and saiety training was given to all employees prior to the start of the project. Trained Geo-Con personnel monitored the site and the health and safety program throughout the project duration.

\section{CONCLUSION}

Deep Soil Mixing is an appropriate form of vertical barrier construction in situations where traditional vertical barrier techniques cannot meet the specified requirements due to soil conditions or contaminated soil conditions present. This project represents the first appiication of Deep Soil Mixing to contain hazardous waste in the United States. 


\section{DEEP SOIL MIXING}

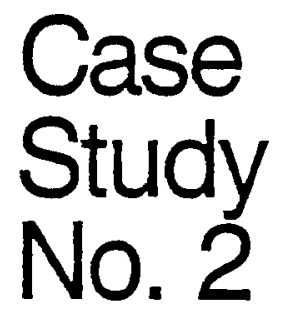

a Geo-Con, Inc Geotechnical Construction Corporate One-Bldg. II Suite 400 4075 Monroeville Blvd. Monroeville, PA $15 i 46$ (412) 856-7700

Regional Offices: $\mathrm{CA}(510) 887-2002$ $\mathrm{Ft}$ (813) 647-5888 TX (817) 383-1400 NJ (609) 848-2220

C-DSM-02-89

\$19so Geocon. ine

\section{DSM Soil Fixation}

\section{APPLICATION}

An environmental study revealed that the soils surrounding a former electrical service shop had been contaminated with PCB's. Although test results showed great promise for in-situ stabilization of the PCB's, there was no acceptable method of applying the chemical in-situ, without excavation, to the 20 foot depth required. Geo-Con's Deep Soil Mixing (DSM) method was selected as the technique of choice to in-situ mix the stabilizing chemicals with the contaminated soil. The actual demonstration test was conducted under the auspices of the USEPA within the Superfund innovative Technology Evaluation (SITE) Program.

\section{LOCALITY}

Hialeah, Florida

\section{WHAT HAD TO BE DONE}

To meet the environmental requirements established by the regulatory agencies, Geo-Con and it's subcontractor evaluated chemical mix designs for environmental and structural compatibility with the soils present.

Geo-Con utilized its single auger Deep Soil Mixing test equipment (Figure 1), consisting of a hollow stemmed mixing auger capable of mixing to depths greater than 25 feel, to demonstrate mixing of the proprietary chemical with the contaminated soil without excavation.

Utilizing Geo-Con's test equipment, two plots of 150 square foot each were stabilized. Precise instrumentation (Figure 2), and a rigid QAVC program allowed variables to be altered to gather exact data on the parameters of mixing and drilling speed and chemical addition rates.

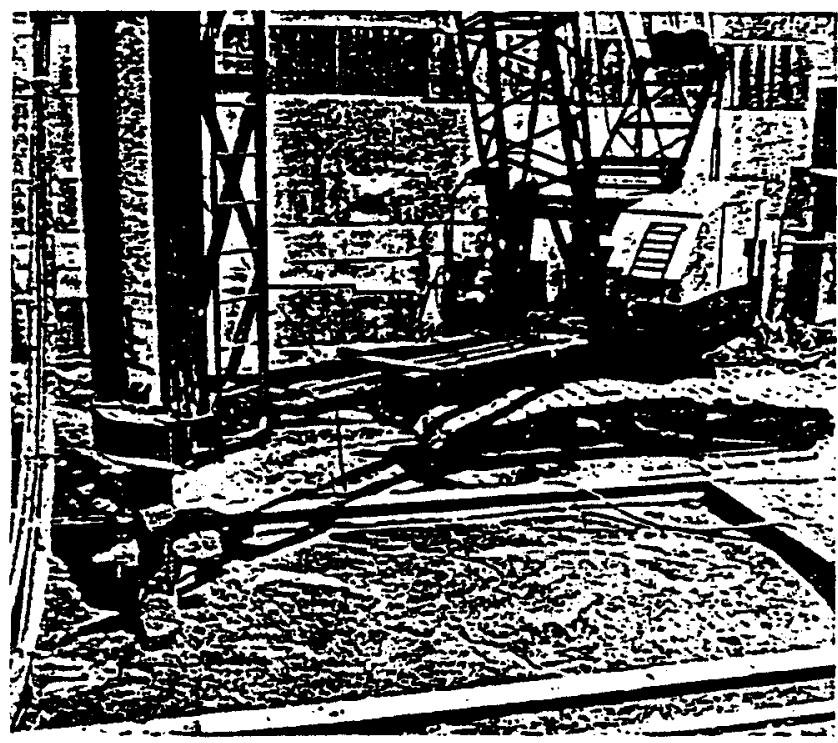

Figure 1
Geo-Con's quality control program included overlapping drilling patterns to ensure complete treatment of all contamination present. Geo-Con also developed a site specific Health and Safety Plan protecting their employees and the neighboring environment during the test.

\section{COMMENTS}

Geo-Con proved that Deep Soil Mixing is a satisfactory

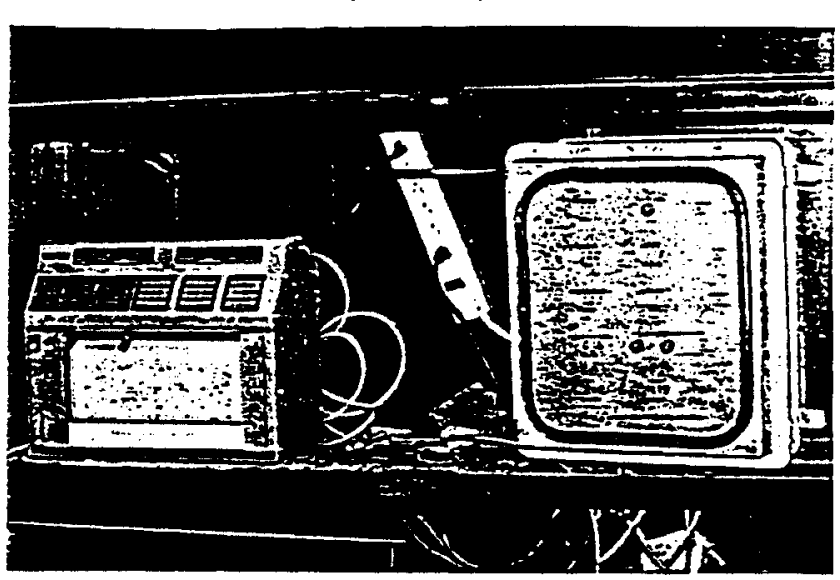

Figure 2 method of mixing fluids with contaminated soils for chemical fixation. Use of Geo-Con's test equipment prior to a full scale remediation program provided the client with firm data at an economical cost. Close cooperation between the owner, geotechnical engineering company, government agencies and Geo-Con resuited in a successful demonstration test program that met regulatory requirements. 


\section{DRILLING AND GROUTING}

\section{Technical Brief}

a Geo-Con, inc. Geotechnical Construction

P.O. Box 17380 Pittsburgh, PA 15235 (412) 856.7700

Regional Offices: CA (408) 453-3587 FL (813) 647-5888

TX (817) 383-1400 NJ (609) 848-2220

T-DG-01-89 D1950 Geocon ine

\section{Grout Curtains For Cut-off and Containment}

The installation of grout curtains by the injection of cement-based grouts, under pressure, into pervious rock formations is a process which has been relied upon for decades in the U.S. to reduce the permeability of these formations. Grout curtains have been utilized primarily as a means of protecting dams by limiting lateral water flow through foundation materials beneath the dam embankment. Installed either during original construction or as a remedial measure for existing dams, grout curtains have been relied upon predominantly to produce a partial cut-off.

Recent improvements in equipment, grout materials, grouting technology, and quality control techniques and equipment have greatly enhanced the cost-eftectiveness of grout curtains on projects which require near or total cut-off and/or contain. ment of subsurface fluids, including contaminated groundwater and hazardous waste materials.

\section{APPLICATIONS}

In addition to the improved performance of grout curtains in conventional embankment rock foundations, grout curtain technology is rapidly being recognized as a cost-effective component in hazardous

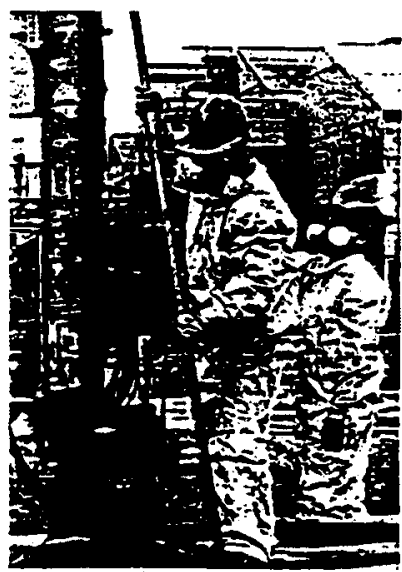
Drilling in hazardous environment. the client.

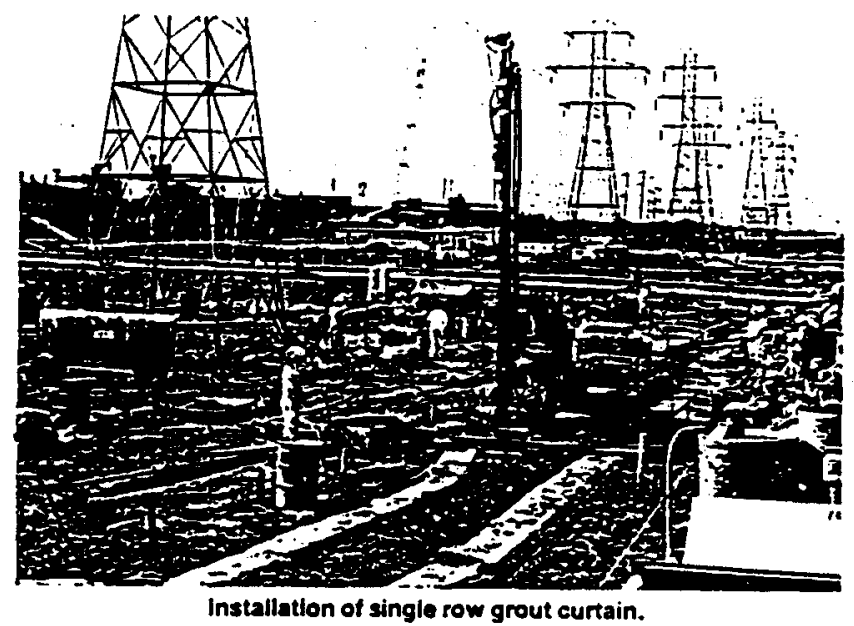

waste containment structures, both for new construction as well as remediation or upgrading of existing structures. A variation of this technique, commonly referred to as "blanket grouting," can also be utilized to install horizontal barriers beneath containment structures. These methods can now be effectively utilized in conjunction with conventional soil cut-off construction procedures such as Deep Soil Mixing (DSM), Shallow Soil Mixing (SSM), jet grouting and slurry trenches in order to extend the soil cut-oif barrier into underlying pervious rock formations. These combination systems can not only increase the effectiveness of existing structures, but can provide increased capacity and protection for new structures, resulting in lower overall containment and remediation cosis to

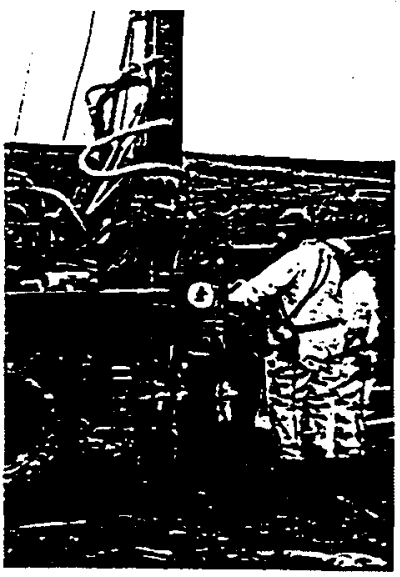

\section{DESIGN AND CONSTRUCTION}

As with any construction technique, final design for construction of grout curtains are site specific and must be a product of sound engineering practice based on a thorough understanding of subsurface geologic and hydrologic conditions at the site and their interrelationships with various construction techniques available. With regard to grouting, the primary design and construction technique variables to be determined include the following:

Geometry: In plan view. grout curtains are typically installed in either single or multiple rows of holes, with the drilling and grouting progressing in a predetermined, ordered sequence typically by the split-space method. Grouting sequence of vertical zones within a particular borehole or group or boreholes is generally performed either by the "downstage" method whereby the uppermost stage is drilled and grouted first and the hole is progressively drilled deeper and grouted in stages until the design depth is obtained; or by the "upstage" method in which the hole is drilled to full design depth and grouting pertormed in the lowest stage first and then continuing upward in stages until grouting of the hole is completed. The utilization of downhole

$$
\text { D. } 10
$$


packers is required for upstage grouting, and is generally preferred for most downstage applications to assure the proper treatment of each grout stage.

Blanket grouting is normally performed in holes installed on a grid pattern with the remaining parameters still considered in the design and varied on a site specific basis.

Materials: The vast majority of curtain and blanket grouting performed to date has involved the injection of neat cement, cement/sand, cement/bentonite, or cement/flyash grout. While these will, in all likelihood, remain for some time the primary materials to be utilized for this work, these materials are limited with regard to the physical size of the fissures into which the material particles can penetrate. In order to provide for more complete filling of these smaller fissures, various chemical grouts have been used over the past few years, but much concern remains over the long term stability of these chemical grout materials.

Recently, however, ultrafine cement-based groutmaterials have begun to gain acceptance in the U.S. This ultrafine material, with individual particle sizes several times finer than normal Portland cements, can provide a muc more complete filling of water paths within the rock formation; and since it is a cementitious material, concerns over longevity are greatly alleviated. When incorporated and used judiciously within the design parameters of conventional grouting technology, this ultrafine grout material can provide significant reductions in formation permeability levels over and above that which would be obtained in a design incorporating only normal cement grout materials.

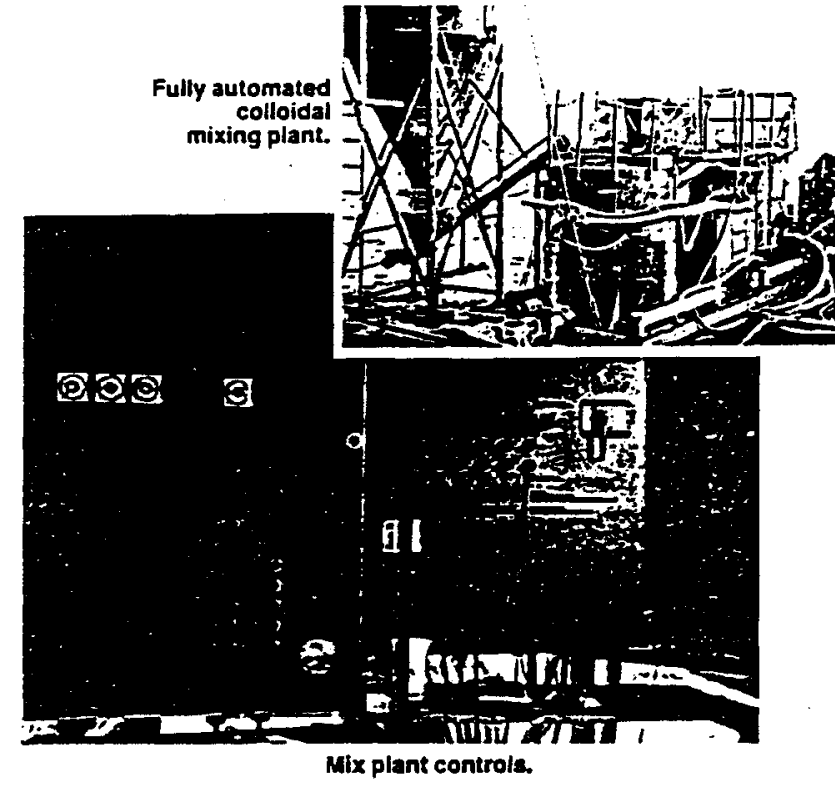

Equipment: The selection of In addition to obvious prodrilling equipment for this work duction advantages, these varies widely within the industry. automated systems not only Appropriate drilling methods in- provide a much more consisclude rotary, rotary-percussion, tent mix, but allow quick and and cased-hole drilling, all utilizing one or more flushing media including air, air-water, water, and bentonitic and polymerdrill fluid additives. The selection of drilling methods and techniques are best made on a site-specific basis.

While numerous types of grout mixing and pumping equipment are available, the use of high speed colloidal mixers is almost uniformly regarded as necessary to the furnishing of high quality grout mixtures. It is further generally believed in the U.S. that progressive cavity pumps provide the most costeffective means of grout injection. While many projects are better suited for manually controlled mixing and pumping, others can be performed much more costeffectively with automated batching and mixing systems.

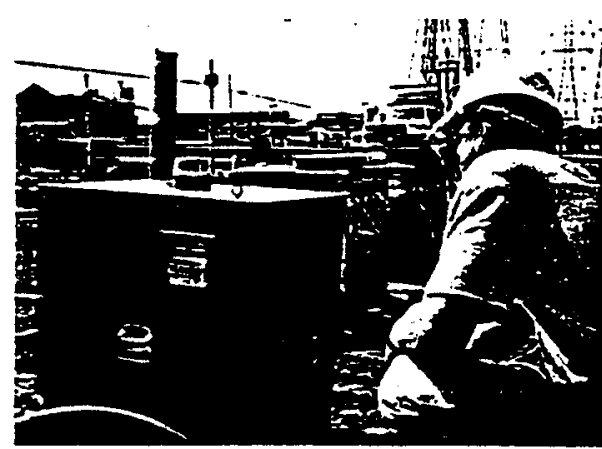

Grout monitor being programmed for operation. mated grout injection monitoring systems.

These systems can not only automatically maintain grout pressure and flow rates within preset limits, but can provide either local or remote readout and recording of injection parameters, and can signal refusal in accordance with preset criteria to a remote operator. These same systems are also utilized for further verification of the work by being employed in water testing of grout stages before and after grouting. This information is then compared with actual injection records and, together, are evaluated in accordance with project design objectives.

\section{CONCLUSION}

These recent improvements and innovations in grouting equipment, materials, and quality control techniques have greatly enhanced the technology of cement grouting such that grout curtains and blankets can now be relied upon to provide effec. tive cut-off and containment of both nonhazardous and hazardous subterranian fluids, and its use will find more and more applications as the need for this type of barrier continues to grow and technological advancements continue to be made.

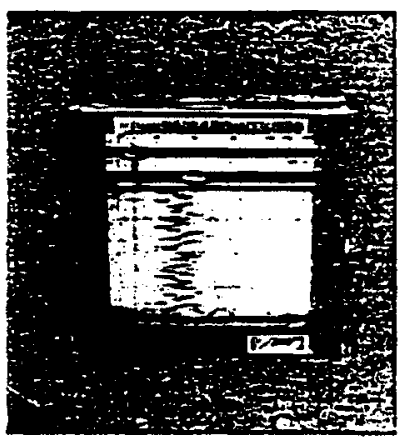

Integral strip chart recorder. 


\section{PIN PILES}

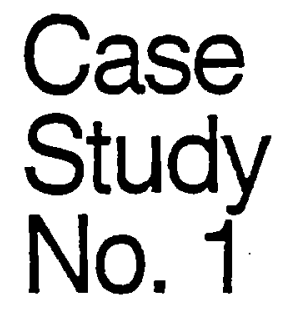

\& Geo-Con, Inc Geotectinical Construction

P.O. Box 17380 Pittsburgh, PA 15235 (412) 856-7700

Regional Otfices: CA (408) 4533588 FL (813) 647-5888 TX (817) $383-1400$ NJ (609) $848-2220$

C-DG7-01-84

\section{Pin Piles Support Settling Wall}

\section{PIN PILE APPLICATION}

A portion of an existing food store was built over a layer of fairty compressible fill. Over the years, a portion of a continuous wall footing had experienced a considerable amount of settlement, up to several inches. Since this food store was making plans to remodel, they had contacted a local geotechnical consultant to investigate and make recommendations on how to prevent any future settlement of the existing wall.

\section{LOCALITY}

Pittsburgh, Pennsylvania

\section{WHAT HAD TO BE DONE}

Working with the geotechnical consultant, Geo-Con proposed the use of small-diameter grouted pin piles to support the existing settling wall. Based on Geo-Con's proposed mended to the client the installation of 52 grouted pin piles within 13 pile caps, each pin pile with a working load of 6 tons. The pin piles were installed in the pile cap excavations using the following procedure: 1. A $11 / 4$ " dia. schedule 80 pipe was driven to bedrock using a disposable closed point. 2. Cement grout was pressure-injected through the pipe while the pipe was extracted five feet. 3 . The pipe was redriven to bedrock through the fresh grout.

\section{COMMENTS}

By working with Geo-Con, the consultant was able to save his client a considerable cost over other underpinning schemes. Al 52 pin piles were installed with limited head room in less than one week. system, the consultant recom-
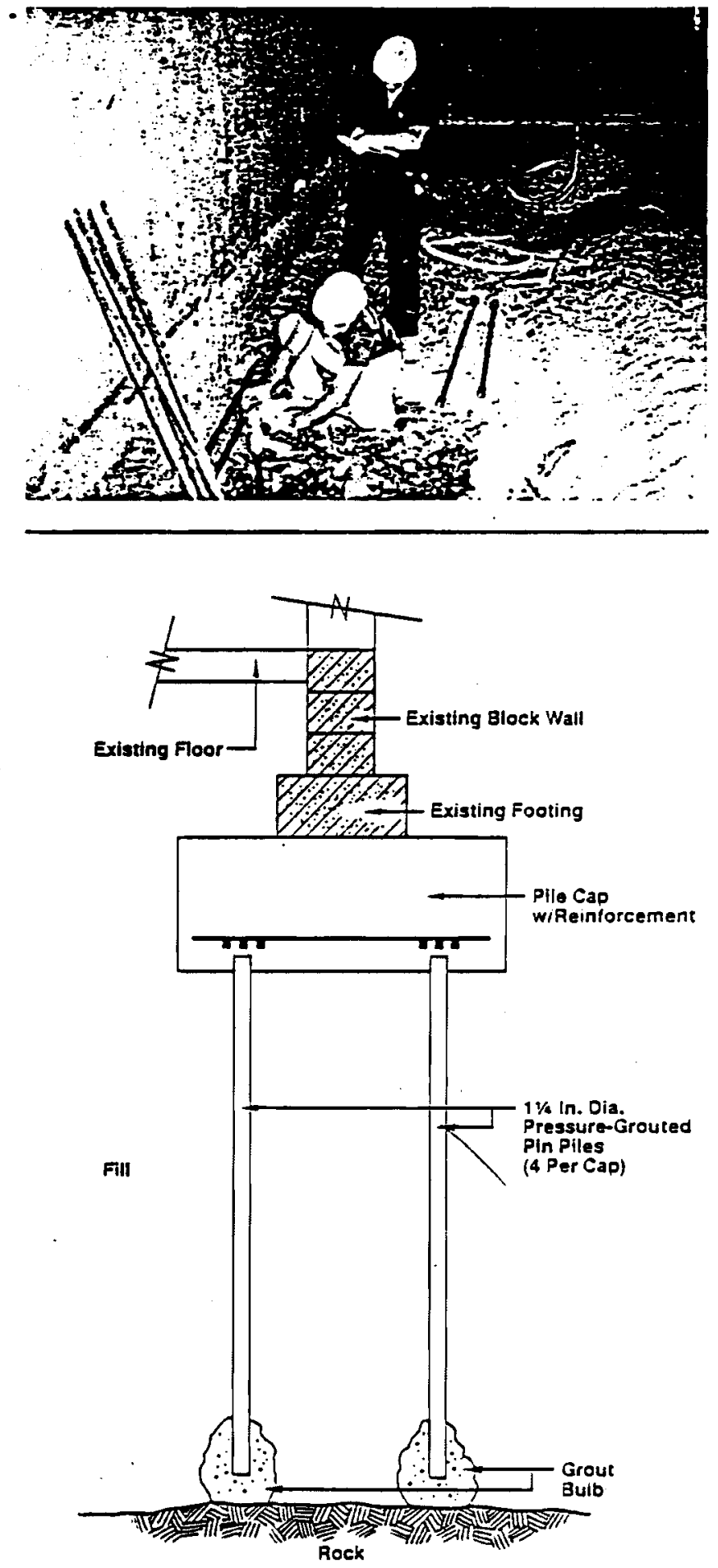


\section{COMPACTION GROUTING}

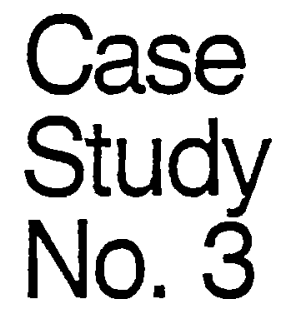

Geo-Con, Inc Geotechnical Construction

P.O. Box 17380

Pittsburgh, PA 15235

(412) $8560-7700$

Regional Offices:

CA (408) 453-3587

FL (813) 647.5888

TX (817) 383-1400

NJ $(609) 848 \cdot 2220$

C-DG-03-88

\$1900 Geo-Con. Ine.

\section{Deep Densification for Site Development}

\section{COMPACTION GROUTING APPLICATION}

A 78 acre tract of land in Baltimore Harbor was previously constructed by placing a hydraulic fill into a containment area. The hydraulic fill was contained by a cellular sheet pile cofferdam. This manmade site was the proposed site for a new marine terminal. Underlying this site was a soft organic layer which was compressing due to the weight of the overiying fill material. The resulting movement was jeopardizing the stability of the cofferdam system, and thus, the integrity of the entire site.

\section{LOCALITY}

Baitimore, Maryland

\section{WHAT HAD TO BE DONE}

As part of a Phase I site improvement, Geo-Con was contracted to perform a compaction grouting program to stabilize the area adjacent to the cofferdam, and to improve the bearing capacity of the underlying soil to support the area beneath the proposed highly loaded crane rails.

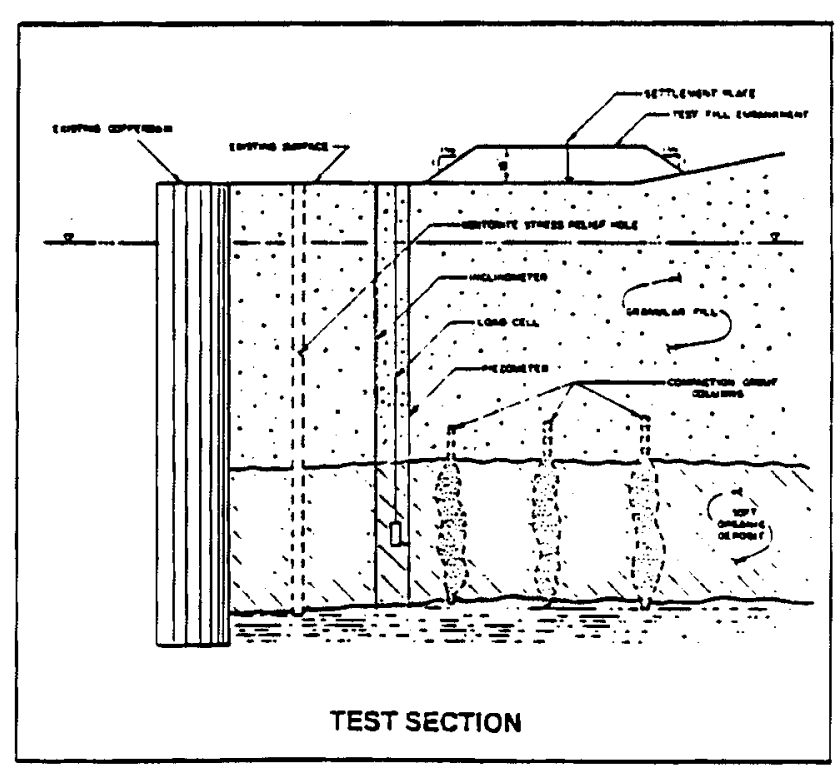

D. 13

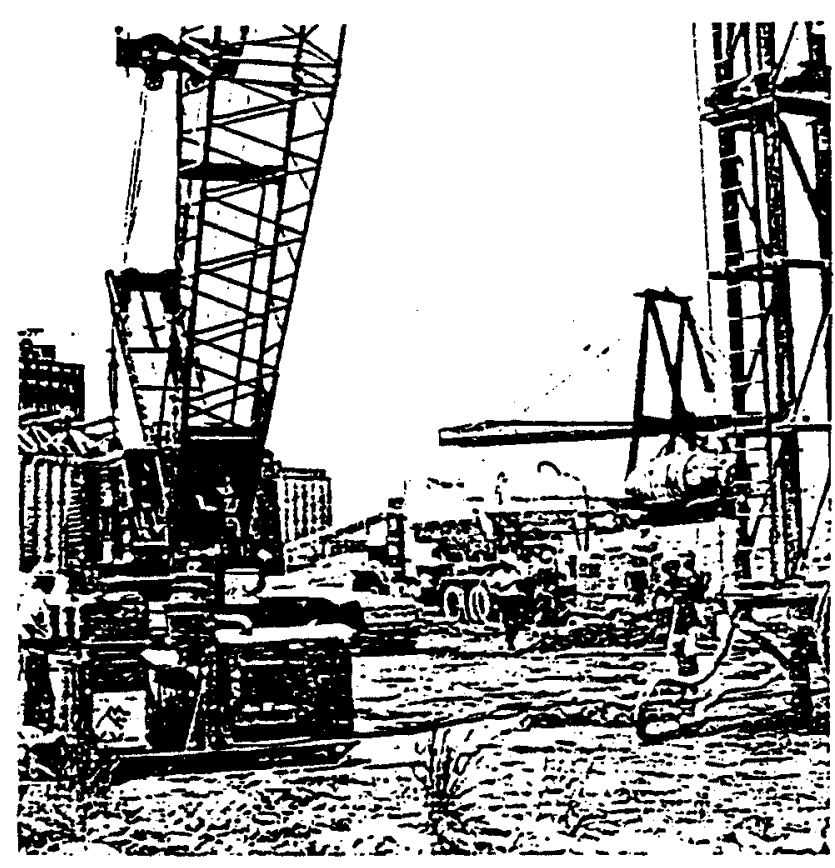

Prior to production work, a test section was performed to determine column spacing, grout pressures and other factors necessary for a suc. cessful grouting program, while not affecting the stability of the existing cofferdam.

Using high production, crane mounted drilling equipment. and automated grout mixing and pumping equipment. Geo-Con installed over 6,000 individual compaction grout

\section{continuously monitored pres.} sure which was critical in maintaining the stability of the cofferdam, and controlied pumping and litting rates to achieve the required grout injection rate per lineal foot of grout column.

\section{COMMENTS}

Due to the careful selection and fabrication of Geo-Con's equipment, a quality grouting program was carefully performed and completed ahead of schedule on this project. 


\section{JET GROUTING}

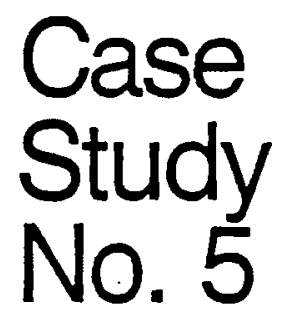

sิ Geo-Con, Inc. Geotechnical Construction Comprate One-Bldg. II Suite 400 4075 Monroeville Blvd. Monroeville, PA 15146 (412) $856-7700$

Regional Offices: CA(510) 887-2002 FL (813) 647.5888 TX (817) 383-1400 NJ (609) 848-2220

C-DG-05-89 $\$ 1990$ Geocon. inc.

\section{Jet Grouting for Vertical Barriers}

\section{JET GROUTING APPLICATION}

An area within a chemical plant required the construction of a vertical containment barrier to stop the flow of phenols in the groundwater. The site is bordered by an existing slurry trench cutoff on one side and a clay cutoff on the other. The project required joining the two existing vertical barriers with an impervious wall to complete a permanent cutoff.

Several underground utility crossings consisting of numerous pipelines at varying depths complicated the normal trenching procedure.

\section{LOCALITY}

Northern Michigan

\section{WHAT HAD TO BE DONE}

The first phase of the project involved the installation of soil/bentonite slurry trench sections, terminating at each utility crossing. A jet grouted "cutoff" wall at each crossing then had to be installed and keyed into the new slurry trench and meet the required $1 \times 10^{-7}$ permeability, without removing or disturbing the existing utilities.

A preliminary test program demonstrated the effect of high pressure grout on the various pipeline materials. Varying pressures were tested on the conduit materials to establish maximum contact pressures and distances without damage to the utilities. Test columns were also constructed and later excavated to confirm the column diameters that could be achieved. This information was used to confirm that wall continuity could be maintained below larger diameter pipes, and that jet grouting could be effectively utilized without damage to the operating utility lines.

Individual holes were drilled between the existing pipes

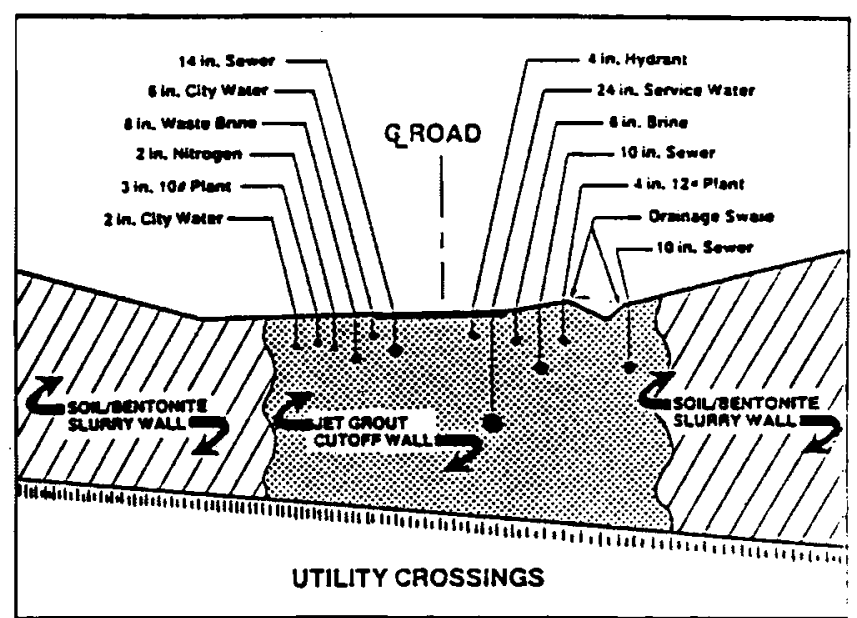

and overlapping soilcrete columns were constructed using the single stem jet grouting method. Holes were typically placed on twentyfour inch centers and grouted at pressures of 5,000 p.s.i. using a cement/bentonite grout to yield the required twenty-four inch wall thickness, and the desired permeability. Pressures and lifting rates were varied near the existing pipelines to eliminate damage or increase the column diameter.

In addition to initial testing, a daily Quality Control program to monitor grout viscosity, flow rates and pressures out the project. Insitu samples were also taken from the com. pleted jet grout wall at columr interconnect points to verify continuity and provide samples for permeability testing.

\section{COMMENTS}

Despite adverse weather, the project was completed prior to the DNA deadline. The jet grouting operation proviced the desired cutoit without interruption of plant produc. tivity, which would have beer required had the various utili. ties needed to be temporarily shutdown and relocated. insured consistency through-

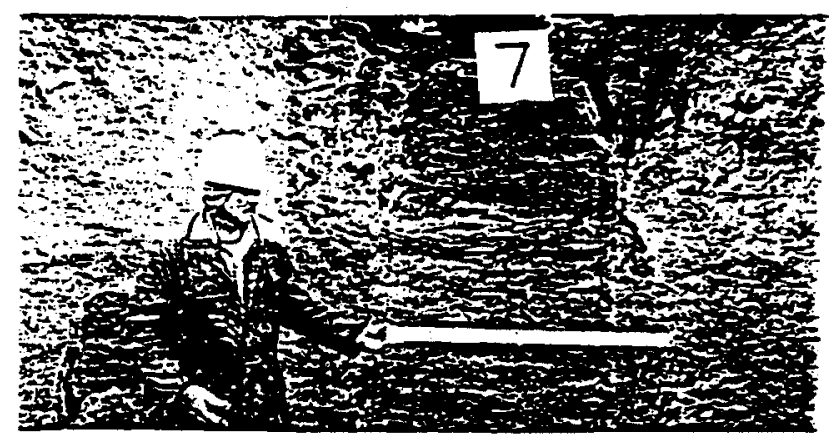

Jet Grout Test Column

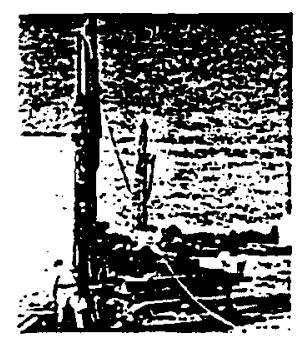

Jet Grout Drill

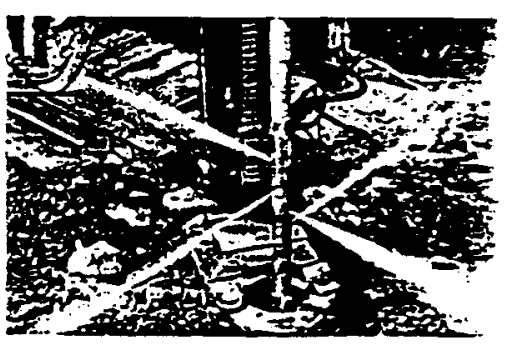

Single Stem Jet System 
PNL-9335

UC-602

\section{Distribution}

No. of

Copies

\section{OFFSITE}

2 DOE/Office of Scientific and Technical Information

J. S. Walker

U.S. Department of Energy

Trevion II Building

12800 Middlebrook Road

Germantown, MD 20874

S. Morrison

Chem-Nuclear Geotech, Inc.

P.O. Box 14000

2597 B3/4 Road

Grand Junction, CO 81502-5504

4 Ebasco Environmental

$1201 \mathrm{Jadwin}$ Avenue, Suite 202

Richland, WA 99352-3429

W. H. Riggsbee

R. L. Treat

H. J. Stansfield

R. M. Schwarz
No. of

Copies

\section{ONSTTE}

DOE Richland Operations Office

D. E. Trader

K8-50

4 Westinghouse Hanford Company

R. G. Alexander

H4-14

M. C. Hagood

H6-04

C. H. Kindle

H6-05

S. J. Phillips

H4-14

25 Pacific Northwest Laboratory

J. E. Amonette

K6-82

K. J. Cantrell (10)

K6-81

J. S. Fructer

G. W. Gee

M. A. Gerben

M. E. Peterson (2)

K6-96

K6-77

P8-38

K2-47

M. H. Schlender

B1-40

R. J. Serne

K6-81

Publishing Coordination

Technical Report Files (5)

\section{Routing}

R. M. Ecker

Sequim

M. J. Graham

K6-78

P. M. Irving

K6-98

C. S. Sloane

K6-04

P. C. Hays

K6-86

K. L. Manke (last) 
